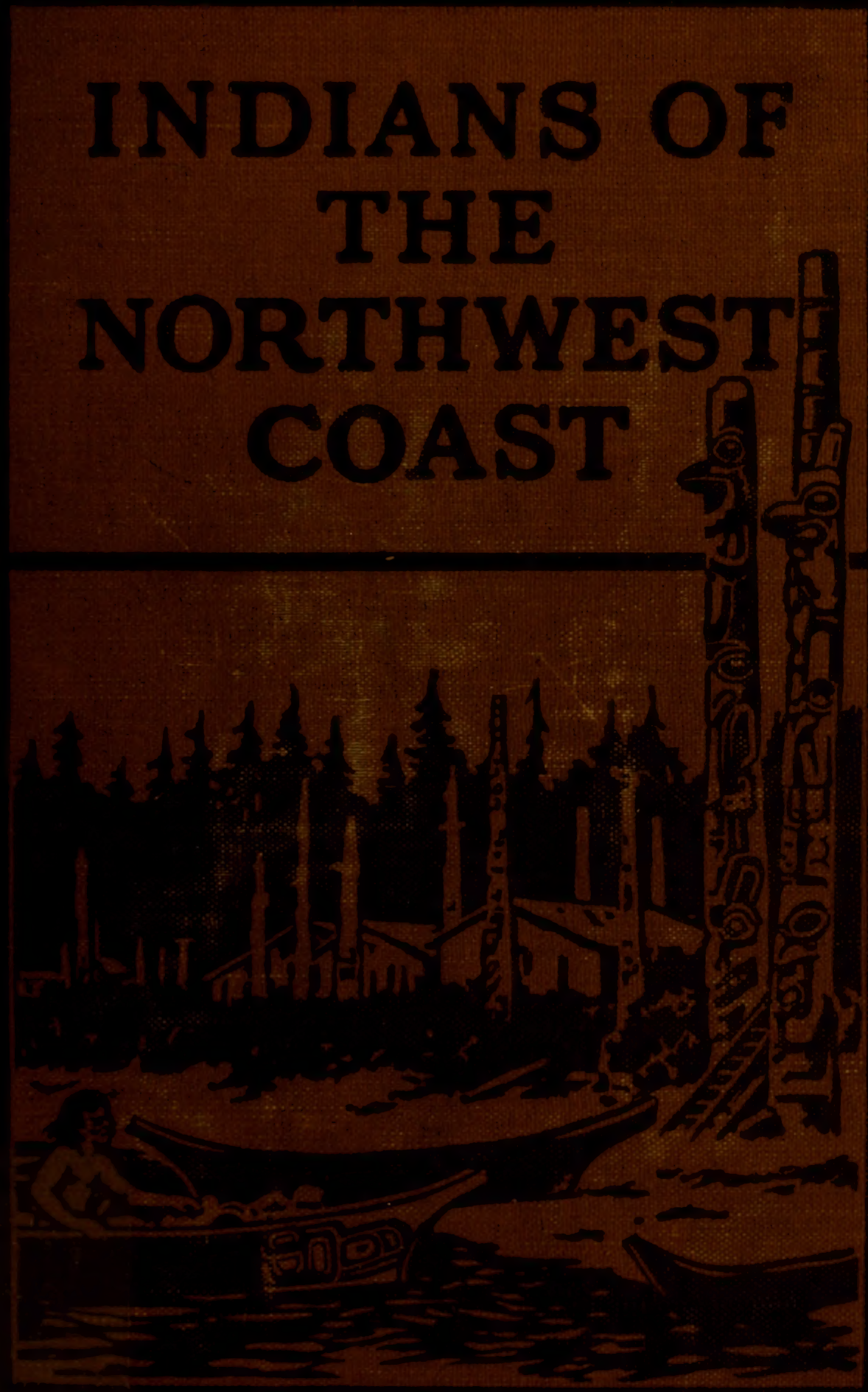




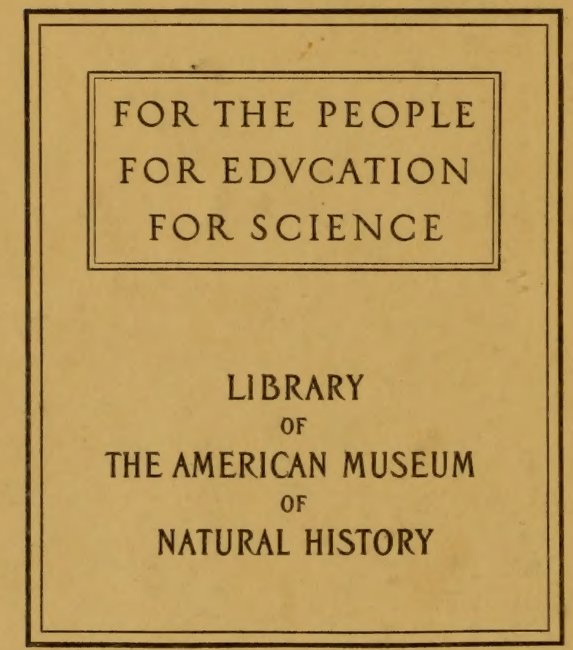


$x^{2}+x^{2}=$

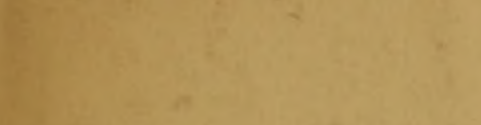

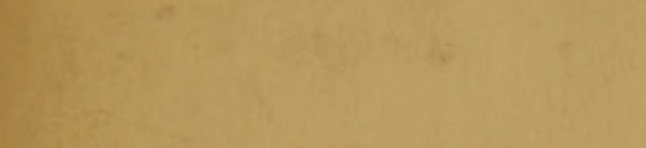

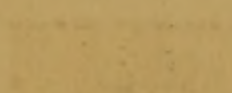

$=$

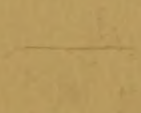

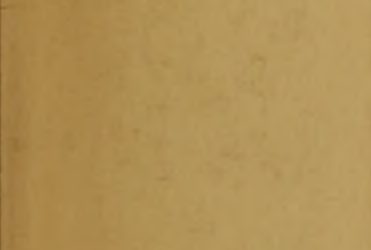

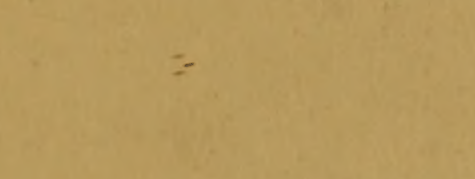

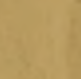




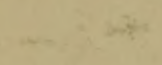

1. 

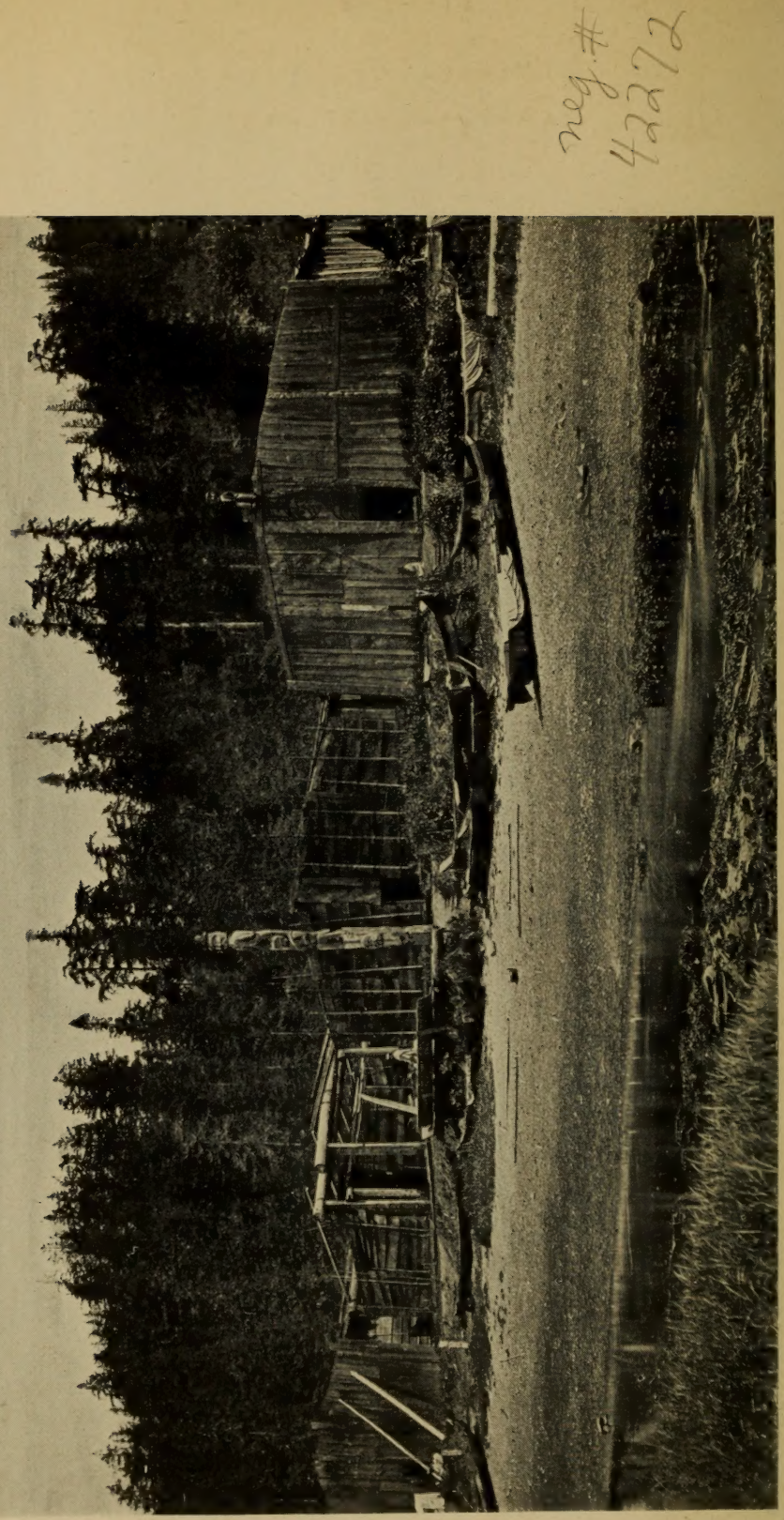

 
AMERICAN MUSEUM OF NATURAL HISTORY

\section{INDIANS OF THE NORTHWEST COAST}

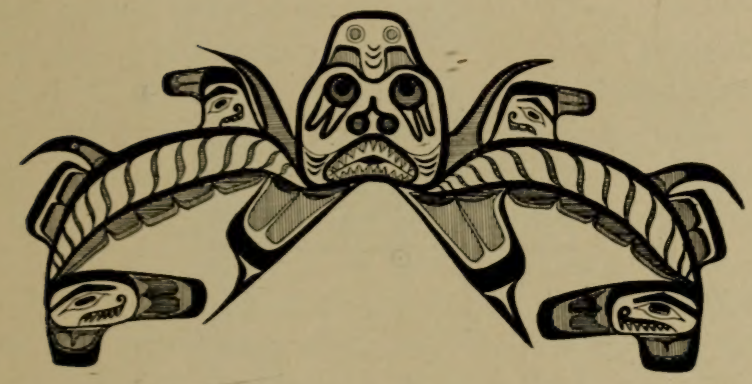

By PLINY EARLE GODDARD

CURATOR OF ETHNOLOGY

HANDBOOK SERIES No. 10

NEW YORK

1924 


\section{The Northwest Coast Hall.}

Displayed in this hall are the collections from the Northwest Coast tribes and also from the tribes living on the Fraser River and its tributaries. On the west side of the hall beginning at the entrance (south) are the Nootka, Kwakiutl, and Tlingit; on the east side the Thompson, Lillooet, Coast Salish, Bella Coola, Tsimshian, and Haida. The central aisle contains a large dugout canoe filled with figures of Northwest Coast men; a model of a Kwakiutl village; and a Kwakiutl family group illustrating their industries.

On the walls and columns of the hall are many examples of Northwest Coast carvings including masks, grave monuments, house posts, and totem poles. There is also on the walls a series of paintings in oil illustrating the life of the Northwest Coast. The pictures on the west wall are devoted to industries and those on the east to ceremonial and religious performances. The south wall has a large painting illustrating the pleasures of peace and a companion picture is soon to be placed on the north wall representing a returning war party celebrating a victory. These murals are the work of Will S. Taylor who has devoted many years to their execution.

The specimens in the eases were obtained partly by purchase and partly through expeditions. A collection mostly from the Haida, made in part by Dr. J. W. Powell, was presented by Heber R. Bishop in 1882 . Two very complete and extensive collections, mainly from the Tlingit, made by Lieut. Geo. T. Emmons during many years spent among them were purchased in 1888 and 1894. Practically all the remainder are the result of the Jesup North Pacific expedition, planned by Prof. F. W. Putnam and Prof. Franz Boas, supervised 
by Prof. Boas, and financed by Morris K. Jesup when he was President of the Museum. The Nootka collection was made by Filip Jacobsen and Geo. Hunt, the Kwakiutl and Bella Coola collections by Prof. Boas and Geo. Hunt, and the Thompson and Lillooet by James Teit. 


\section{PREFACE.}

The collections of ethnological specimens illustrating the life of the tribes of North America north of Mexico are at present arranged in four exhibition halls on the first floor of the Museum. These are: first, a hall devoted to the tribes east of the Mississippi and in northern and eastern Canada; second, the peoples of the Great Plains between the Rocky Mountains and the Mississippi; third, the southwestern region where are found the Pueblos and the Navajo, Apache, and Pima; and fourth, the Northwest Coast.

Realizing that museum collections at the best can only in part portray the life of a people, a series of handbooks was planned to supplement these exhibits. Dr. Clark Wissler wrote the first of the series, "Indians of the Plains," published by the Museum in 1912, second edition, 1920. The writer prepared the second, "Indians of the Southwest," in 1913 and revised it for the second edition in 1921.

Much of the work of securing the collections for the Northwest Coast hall, the original arrangement and labeling, and the editing of the publications describing them was done by Prof. Franz Boas of Columbia University who was a Curator in the Museum from 1902 to 1906 and since then Editor of the Jesup Publications. This handbook is based almost solely on these publications and many of the illustrations are taken from them. In addition to supplying the basic material, Prof. Boas has been kind enough to read the manuscript and give much aid in the preparation of this book. For this, grateful acknowledgment is here made.

During the summer of 1922 the writer had the privilege of visiting many of the Indian villages of the coast of British Columbia in the company of Dr. C. F. 
Newcombe from whom much ethnological information was obtained. A week was spent among the Tlingit at Sitka with Lieut. George T. Emmons, whose long acquaintance with the Tlingit was most helpful in securing an insight into their culture.

At Bella Coola, Mr. T. M. MeIlwraith was found engaged in ethnological fieldwork. There and later in New York, Mr. McIlwraith discussed Bella Coola social and ceremonial life, making available for publication in this handbook his unpublished results.

May, 1923. 


\section{CONTENTS.}

\section{CHAPTER I.}

INTRODUCTION

Habitat: Tribes Included. Topography. Climate. Trails. Flora. Fauna. Early History: Discovery. Spaniards. Captain Cook. De la Perouse. Trading Ships. Vancouver's Survey. Mackenzie. Fur Trade. Russians.

\section{CHAPTER II.}

\section{Material Culture}

Houses: Of the Salish. Of the Nootka. Of the Kwakiutl.

Chilkat Houses. Platforms. Coöperatively Built. Canoes: Types. Sizes. Methods of Propelling. Work in Wood: Tools. Felling. Splitting Planks. Bending Wood. Dugout Dishes. Canoe-making. Sewing Wood. Textile Arts: Nets. Matmaking. Basketry. Tlingit Baskets. Cedar Bark Blankets. Chilkat Blankets. Salish Blankets. Food Getting: Whaling. Hunting Porpoises. Sealing. Halibut Fishing. Cod Fishing. Salmon. Weirs. Gaff Hook. Olachen. Herring. Shellfish. Vegetable Food. Raising Tobacco. Land Animals. Dress and Decoration: Barefooted. Men's Clothing. Women's Dress. Tattooing. Deformed Heads.

\section{CHAPTER III.}

Social and Political Organization.

Social Distinctions: Slavery. Social Rank. Feasts. Inherited Duties. Chiefs. Septs. Rivalry of Chiefs. Linguistic and Geographical Groups. Exogamous Divisions. Puberty. Burial Customs: Tree Burial. Canoe Burial. Cremation. Memorial Columns. Marriage: Selection of Mates. Marriage Customs. Games. Warfare: Armor. Weapons. Motives for Fighting. Methods Employed. Trophies. 


\section{CHAPTER IV.}

RELIGION

Religious Beliefs: Supreme Being. Haida Deities. Bella Coola Deities. Gods of the Kwakiutl. Salmon People. Religious Practices: Ceremonial Cleanness. Offerings. Taboos. Shamanism: Curing Methods. Other Duties. Peculiar Dress. Winter Ceremonies: Kwakiutl Ceremonies. Their Societies. Return of the Novice. Cannibalism. Magic Performances. Supernatural Visitors. Haida Ceremonies. Tlingit. Potlatch: Potlatch Occasions. Wealth Necessary. Distribution of Wealth. Purpose of Potlatch. The Future World. Mythology and Folklore: Raven Myths. Family Traditions.

\section{CHAPTER V}

ART

Textile Decoration. Carving. Grotesque Art. Totem Poles.

Conventionalizations. Carved Ornamentation. Rearrangements and Dissections. Symmetry. 


\section{MAPS AND ILLUSTRATIONS}

Kwakiutl Village on Salmon River, Vancouver Island. Frontispiece

Ethnological Map of the Northwest Coast

The Valley of the Bella Coola River down which Mackenzie came, in 1793. Photo. by H. I. Smith . . . . . . 18

Method of Erecting House Posts. Kwakiutl . . . . . 27

Skidegate Village on Queen Charlotte Islands. Haida . . . 28

House with Modified Front. Haida . . . . . . 28

Method of Raising House Beams. Kwakiutl . . . . . 29

House at Klukwan Village. Tlingit . . . . . . . 30

Fishing Village at Kisgagas on a Tributary of the Skeena River, British Columbia. Photo. by C. M. Barbeau . . . 30

Interior of House Showing two Terraces with Fire below and Sleeping Compartments above. House_of Chief Weir at Masset, a Haida Village

The Northern Type of Canoe with Projecting Bow and Stern. Haida

Bailers for Canoes. Kwakiutl 35

Paddles . . . . . . . . . . . . 35

Long-handled Adze . . . . . . . . . . . 36

Set of Seven Wedges in the End of a Log . . . . . $\quad 37$

Wedges L'sed for Splitting Boards from Logs. Kwakiutl . . 38

Hand Hammers . . . . . . . . . . . 38

Carving Knives. Drill with Bone Point. Kwakiutl . . $\quad 39$

Chisels with Bone Blades. Kwakiutl . . . . . 40

Hand Adze with Blade of Stone. Nootka . . . . 41

Hunter's Boxes. Board Cut for Folding to Make Such a Box.

Kwakiutl . . . . . . . 42

Wooden Vessels. Kwakiutl . . . . . . . 43

Oil Dishes, Dug out of Alder Wood. Kwakiutl . . . 43

The Joined Corner of Box with Stitching Indicated. Kwakiutl . 44

Box with Projection on Lid. Kwakiutl . . . . . . 44

Method of Joining Boards by Sewing. Kwakiutl . . . . 45

Spindle Lised for Nettle Fibre. Kwakiutl. . . . . 46

Details of square and Diagonal Mat Weaving. Kwakiutl . . 47

Twilled Belts of Cedar Bark. Kwakiutl . . . . . . 48

Basket of inrure Ront, Birdrage Ntitch. Double Basket of C'heckerwork. Kwakiutl . . . . . . 49

Hat of sipruce Root with its Cover of Cedar Bark. Kwakiutl . 49

Detail of Openwork Mat. Kwakiutl . . . . . . . 50 
Twilled Pouch of Cedar Bark. Kwakiutl

Berrying Basket with its Carrying Strap. Carrying Strap used by

Mountain Goat Hunters. Kwakiutl . . . . $\quad 50$

Bag, Illustrating Open-twining. Kwakiutl . . . . . . 51

Tlingit Basketry . . . . . . . . . . . . . 52

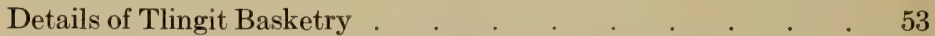

Implements for Shredding Cedar Bark. Kwakiutl. . . . . 54

Beater for Cedar Bark. Kwakiutl . . . . . . . 55

Detail of Suspending a Chilkat Blanket _ . . . . . . $\quad 56$

Pattern Board from which Women Weave Chilkat Blankets . $\quad . \quad 57$

Spindle Whorls . . . . . . . . . . . 58

Float Made of Seal's Bladder. Kwakiutl . . . . . . $\quad$. 60

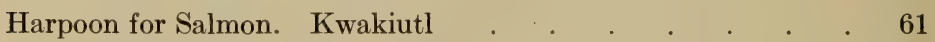

Halibut Hooks Set in Pairs. Kwakiutl . . . . . . . 62

Dam and Fish Trap. Kwakiutl . . . . . . . . 64

Dam and Fish Basket, for Salmon. Kwakiutl . . . . . 64

Trolling Hook for Salmon. Clubs for Killing Halibut. Kwakiutl 65

Salmon Trap for Narrow Streams. Kwakiutl . . . . . 66

Weir for Olachen Fishing. Kwakiutl _ . . . . . . . . $\quad$. 67

Salmon Drying. Chilcat River, Alaska . . . . . . 68

Olachen, or "Candlefish" in Storage . . . . . . . . . 70

Rendering Olachen Oil in a Canoe by Means of Hot Stones . $\quad$. 70

Pile Divers . . . . . . . . . . 71

Herring Rake. Kwakiutl . . . . . . . . . . . 72

Digging Sticks. Kwakiutl _. . . . . . . . . . . 73

Fish Basket. Kwakiutl . . . . . . . . . . 74

Crab Net. Kwakiutl . . . . . . . . . . . . 74

Tongs . . . . . . . . . . . . . . 75

Bird Spear. Nootka . . . . . . . . . . . . . 77

Bows. Kwakiutl. Arrows. Kwakiutl . . . . . . 77

Spring Trap : Used for Bear, Deer, and Smaller Animals.

Kwakiutl . . . . . . . . . . . 79

Deadfalls. Kwakiutl . . . . . . . . . . 79

Hat on Which Whale Hunting is Depicted. Nootka . . $\quad$. 80

Woman's Apron. Kwakiutl . . . . . . . . 81

Ornaments: a, Anklet; b, Bracelet. Hair Ornament of Dentalia

Shells. Kwakiutl . . . . . . . 81

Cradle with Cedar Bark Bedding. Kwakiutl _ . . . . $\quad$. 82

Kwakiutl Woman with Deformed Head. Sugarloaf Type . $\quad .83$

Nose Ornaments of Abalone Shell. Kwakiutl. . . . . . 84

A Chief with his Broken Copper. Kwakiutl . . . . . . 91

A Copper: Design, Horned Owl . . . . . . . . . . . 92 
Tree Burial near Alert Bay, B. C. Kwakiutl .

Grave Post with Cavity in the Back of the Figure in which an Incincrated Body has been Placed. Wrangell, Tlingit

Memorial Columns, Anthony Island. Haida. Photo. by Dr. C. F. Newcombe

Double Ended and Double Bladed Knife, Made of Bone of Whale. Tlingit

107

War Club Made of Whale's Rib. Tlingit . . . . 108

Weapon of Jade Inserted in Wooden Handle. Tlingit . . . 108

Model Representing a Shaman with Raven Symbols. Haida . 119

Model of a Shaman's Grave Box. Haida . . . . . 120

A Youth Showing the Hemlock Decoraton of a Novice. hwakiutl

124

Fool Dancers of the Winter Ceremony. Kwakiutl . . . . 126

Cannibal Society of Winter Ceremony. Kwakiutl . . . 126

Checker Design on a Mat. Kwakiutl - . . . . . . . 142

Decoration Produced by Varying Direction of Elements in Twilling. Kwakiutl

Baskets Illustrating Geometrical Designs. Tlingit . . . 144

Haida Village of Tanu, Queen Charlotte Islands. Photo. by Dr. C. F. Newcombe

Painted House Front: Thunderbird Carrying off a Whale. Alert Bay. Kwakiutl

Support of a Grave Box Carved to Represent a Beaver Wearing a Hat. Haida .

Masks Representing Supernatural Beings. Bella Coola.

Double Mask: Closed, Raven as a Bird; Open, Raven as a Man. Haida

Harpoon Rest for Bow of Canoe. Kwakiutl .

Models of Haida Totem Poles

Front and Back of a Box: Moon as a Bird (above); Mountain Goat (below)

Totem Pole in the Museum. Haida

Memorial Column in the Museum. Haida . . . . . 151

Totem Pole. Haida

Facial Paintings. Haida

Masks and Rattle. Woman with Labret is represented in 2 . Haida

Rattles. Design a Hawk. Tlingit

Dish of Mountain Sheep Horn Representing a Hawk. Tlingit . 155

Grease Dish in Shape of a Seal. Tlingit . . . 156

Settee with Family Emblems Carved on the Back. Kwakiutl 157 
Paint Brushes. Kwakiutl . . . . . . . . 157

Club Representing a Killerwhale with Dorsal Fin Bent down.

Tlingit . . . . . . . . . . 158

Bow of the Large Canoe in the Museum . . . . . . 158

Painting of Shark Cut Apart and Spread Open. Haida . . 159

Tattoo Designs. Haida . . . . . . . . $\quad .159$

Painting from a House Front Showing a Bear as if Cut Along the Back, Giving a Symmetrical Treatment Either Side of Circular Door. Tsimshian . . . . . . . . . 160 Above, Animal Representations Adjusted to Hats: Below, Leggings. Haida . . . . . . . . . . 161

Shirt with Designs Similar to Those on Blankets. Tlingit . . 162

Dancing Apron. Tlingit . . . . . . . . . . 162

Designs on Chilkat Blankets $\quad$. . . . . . . . . . . . . 163

Designs on Chilkat Blankets _. . . . . . . . . 164

Design on Chilkat Blanket: Positions of Anatomical Parts are Indicated . . . . . . . . . . . 165 


\section{Chapter I \\ INTRODUCTION.}

\section{Навітат.}

In delineating the area to be included under the term Northwest Coast it is necessary to be somewhat arbitrary. It is desired to treat in this book those peoples who participate in a civilization which is characterized by the possession of large rectangular wooden houses and of dug-out canoes, whose dress was scanty, who depended almost entirely upon the sea for food, who hold in great regard those persons who are of pure descent and benevolent in the disposal of property, and who have a conventionalized grotesque art.

Tribes Included. Toward the north there is no difficulty in deciding what tribes are to be included. First are the Tlingit, who have all the above-mentioned peculiarities. North of the Tlingit along the coast are the Eskimo who, while they somewhat resemble in culture the peoples of the Northwest Coast, are much more closely connected with the main body of Eskimo in race, language, and habits. The neighbors of the Tlingit, toward the east in the interior, are Athapascanspeaking and while they have been somewhat influenced by their coast neighbors there is no hesitation in classifying them with their relatives further to the east and in the valley of the Yukon. South of the Tlingit are the Haida, who in many respects may be looked upon as typically of the Northwest Coast culture. Their position is geographically nearly midway north and south. They have for neighbors on the east the Tsimshianspeaking tribes of closely similar culture. The Tsimshian live mainly on the Nass and Skeena rivers, their villages extending for quite a distance up these rivers into a somewhat different environment and a less 
humid climate; they maintained, however, a life quite similar to that of the coast people, securing through trade those products which are naturally limited to the sea. East of the Tsimshian are Athapascan tribes strikingly different in nearly every respect.

When consideration is given to the tribes of the south, however, the question becomes more complicated. It will be more convenient to discuss them first by referring to their speech. They belong to two separate linguistic classes; the Wakashan and the Salish. The former consists of two languages, the Kwakiutl and Nootka; the main body of the Kwakiutl are on the northern part of Vancouver Island, the neighboring smaller islands, and the adjacent mainland to the east. Geographically isolated to the north are two dialects; the Haisla and the Heiltsuk, the best known tribes being the Bella Bella, bordering on Fitzhugh Sound and the Kitlope on Gardiner Channel. They are separated from the other Kwakiutl and affiliated closely with a Salish-speaking people, the Bella Coola, who live on Burke Channel and its extensions. The Nootka are confined to the west coast of Vancouver Island, unless one includes with them the Makah, a tribe closely related in speech living on the American side of the straits of San Juan de Fuca.

The main body of the Salish, from whom the Bella Coola have become separated, occupy a large and continuous area in southern British Columbia and the northern portion of the state of Washington. On Vancouver Island they have the territory on the east side, south of Cape Mudge, and the whole southern end of the island about Victoria. There can be no doubt that the Salish people on Vancouver Island are to be included in those having the typical Northwest Coast culture. It is on the mainland of British Columbia and 
the state of Washington that the boundaries are less definite. Salish-speaking peoples extend up the Fraser River and occupy its large tributary, the Thompson River. These interior people, the Thompson, Lillooet, and shuswap, have never been considered as having the culture of the coast peoples. Their houses, dress, food, religion, and art, are quite different not only from those of the Northwest Coast, but from their other neighbors as well, so that they are perhaps entitled to a culture area of their own, the Fraser. Lower down on the river, however, were formerly tribes participating in both cultures. They made baskets similar to the Thompson, but in many ways, resembled more closely the coast people with whom they are to be classed.

Toward the south in respect to rectangular houses, canoes, dress, food in part, and their regard for birth and wealth, there is an extension of the northwest culture down the coast of Washington and Oregon and into California, as far as Humboldt Bay. The placing of a definite line between this southern extension of attenuated culture into California and the straits of San Juan de Fuca, where it existed rather typically, would be quite arbitrary.

The difficulty is, however, more a logical than a practical one. For the present purpose it will be sufficient to treat as a whole the culture participated in by the tribes enumerated above; those of Tlingit speech, the Haida, the Tsimshian, the Bella Bella, Bella Coola, Kwakiutl, Nootka, and the Salish on Vancouver Island and about the delta of the Fraser.

Topography. In many respects the northern Pacific coast of America resembles that of Scandinavia. Both regions have sometime been subject to remarkable depression, so that the valleys are flooded by the sea and the mountains rise abruptly from the water. 
Long fjords cut deeply into the land, and the streams that enter them are usually rushing mountain torrents. The heavy precipitation results in the steep mountains being covered with green forest or white snow.

Along the coast are several very large islands and innumerable smaller ones, separated from each other and from the mainland by navigable straits. Beginning at the south is Vancouver Island, three hundred miles long and from forty to eighty miles wide. At the north it is separated from the Queen Charlotte Islands by Queen Charlotte Sound which is about forty miles wide. The two larger of the last named islands are Moresby at the south and Graham north of it. Together they reach a length of about one hundred eighty miles; the greatest width of Graham Island being about sixty miles. North of the Queen Charlotte Islands is Dixon's Entrance, cutting them off from the islands of Alaska; the Prince of Wales group, Baranof, Chichagof, and others. Between these large outlying islands and the mainland are many others of varying sizes.

It will be readily seen then that the amount of shore line is very great on such a coast because of the large number of inlets and the great number of islands. This is in very great contrast with the coast of California, where the islands are few, and the coast so abrupt that the tide flows but a short distance up the rivers. On the whole, the northwest coast of America is exceedingly favorable for the development of a culture which depends almost entirely upon canoes for travel and transportation, and upon the sea for its supply of food. The sheltered channels are so continuous that the larger dugout canoes can be brought quite safely from Skagway at the mouth of the Chilkoot River to Victoria, provided favorable iweather is waited for before crossing the two or three more exposed stretches of water. 
Climate. In a second particular the western coast of America can be compared to the western coast of Europe. A warm ocean current, the Japanese in this case, washes the shores of southeastern Alaska and British Columbia, moderating the climate so that the winters are much like those of the British Isles. At the level of the sea the snow does not lie on the ground for any length of time, and the thermometer seldom reaches zero. The rainfall varies greatly according to the particular locality, being influenced by the mountain ranges which cause the precipitation. Fogs and mists are more common nearer the ocean, while the heavier downpours of rain usually oceur along the mainland. Wherever the river valleys are occupied, as are those of the Nass and Skeena, or where the inlets penetrate far into the interior, as at Bella Coola, a less humid climate is encountered with much hotter summers and fairly severe winters.

Trails. For the most part, the interior of the larger islands and the mainland was untraversed by the natives. The greater part of the area is covered by steep and rugged mountains difficult of ascent. The less mountainous portions of Vancouver Island are so heavily forested that travel on foot is extremely difficult. With the exception of the Salish-speaking Cowichan, who live on a river and lake bearing their name, and some of the Nimkish, the Indians everywhere are on the seashore or on the inlets. Vancouver Island was crossed by trails at several places, one was from the head of Alberni Sound to the east coast, another was from Nimkish Lake to Kyuquot and Nootka sounds, and a third trail led from Fort Rupert to Quatsino Sound.

Farther north were the so-called grease trails over which trade was carried on, particularly in olachen oil. 


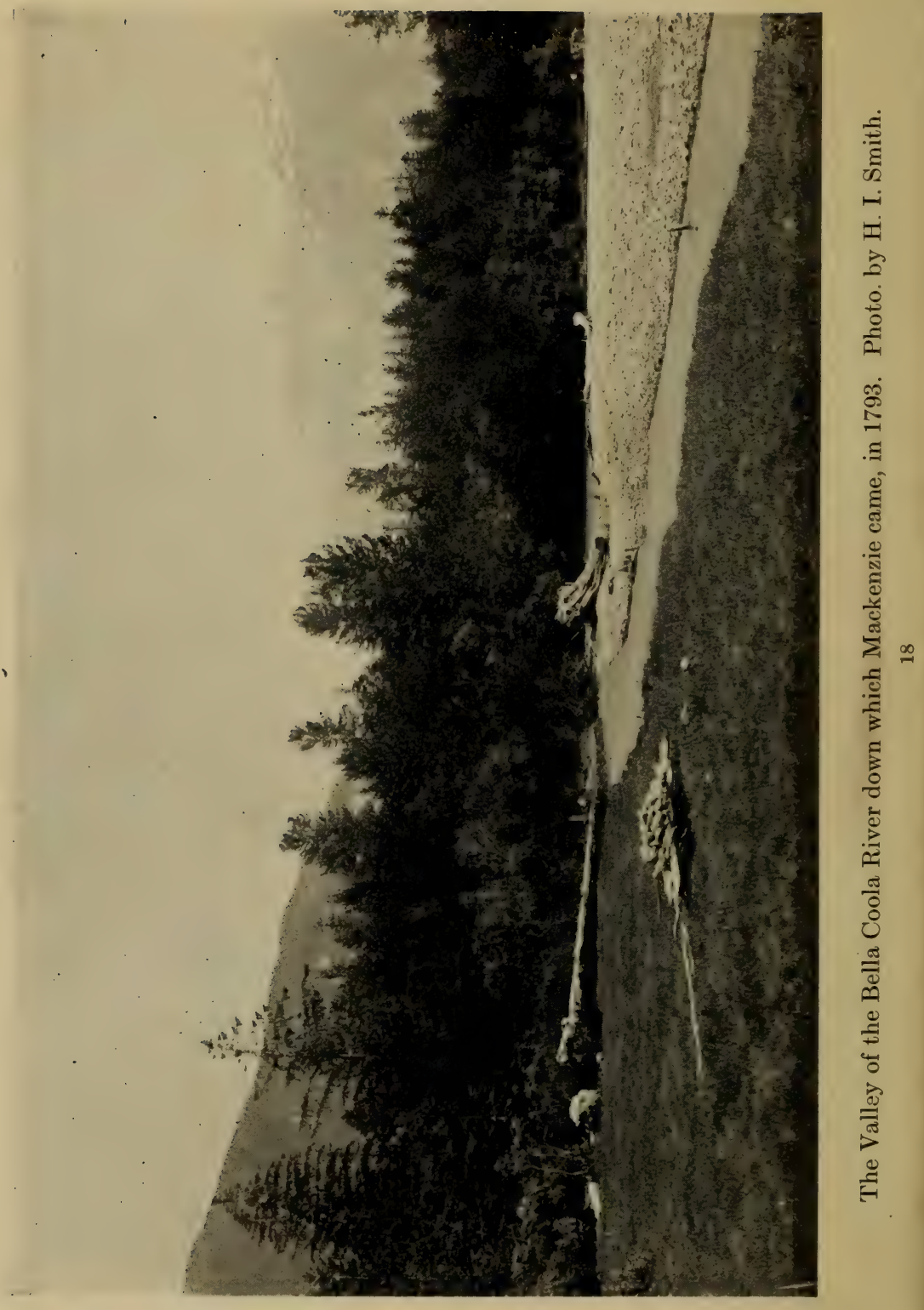


One of the noted inland trails was that along the Bella Coola River, the route followed by Alexander Mackenzie when he accomplished the first crossing of the northern part of the American continent. By means of this trail the tribes of the interior traded with the Bella Coola who in return supplied them with olachen oil and later with arms and ammunition in return for skins and furs.

There were trails also along the Skeena and Nass rivers, and a grease trail passing through Kitwankool connected the two streams. Still farther north, the coast natives about Wrangell traded up the Stikine, and the Chilkat had trails over the passes to the headwaters of the Yukon. These land routes were exceptions. The larger proportion of both travel and trade was by canoe on the salt water.

Flora. Except on the south end of Vancouver Island and in the interior valleys of the rivers and the deep penetrating inlets, the trees are evergreens, chiefly coniferous. Douglas spruce in the south and hemlock and sitka spruce in the north are the prevailing growths. In the south the red cedar, Thuja gigantea, is common while on the Queen Charlotte Islands and on the exterior islands of Alaska the yellow cedar grows. These two trees contribute very much to the life of the natives. On the southern portion of Vancouver Island about Victoria are many deciduous trees; cottonwoods, madroñas or arbutus, and Garryana oaks. On the Bella Coola and skeena rivers are found cottonwoods, used for canoes in the lack of suitable cedar trees, birches, and pines. What is true of the trees is of course also true of smaller vegetation of economic importance; berries plentiful in one locality are quite unknown in others.

Fauna. The fauna of the islands varies considerably, probably for a variety of causes. Elk and moose 
as a rule do not occur on the islands. On some of them there are no black bear, only the enormous brown ones. Mountain goats and mountain sheep are common on the mainland of Alaska and British Columbia and deer are quite generally distributed. Only recently the sea teemed with life of which the killerwhale was the monarch. Of sea mammals, there was a variety of other whales, porpoises, sea-lions, and seals. From the ocean itself the natives secured halibut and cod; and at certain seasons of the year the migrating salmon filled the inlets on the way to their breeding grounds in the rivers. The oil-furnishing olachens visited certain of the larger rivers in early spring. They were particularly numerous in the Fraser, Kitimat, Nass, and Chilkat rivers.

In this very favorable environment, with its abundant food supply, grew up, since the retreat of the last great ice age, a very rich and special culture, quite unlike, in most respects, any other in aboriginal America.

Early History.

Discovery. The Pacific Coast of North America was visited first by Francis Drake in 1578 but he came north only as far as Bodega Bay, California, Lat. $38^{\circ} 18^{\prime}$, far south of the region of our particular interest. Jean de Fuca, however, discovered the entrance of the strait which bears his name in 1592 .

The first landing on the northern coast appears to have been made in July 1741 by the Russian explorer, Behring, and Tschirikow, captain of one of Behring's ships. The latter anchored near Sitka and sent an officer with ten men ashore for water. The boat landed behind a point and the pre-arranged signals for safe landing were seen. When after some days the party did not return, a small boat with four men was sent to learn 
the cause of the delay. Neither boat returned, but some days later two boats being rowed were seen in the distance. Tschirikow, thinking his two lost boats were coming, mustered the crew on deck. These boats were in reality manned by natives who, when they saw so many aboard the ship, returned with all speed. The captain had no other boats and the coast was too rough and the wind too strong to permit the ship to approach nearer to the land. He was obliged to sail away and leave his boat crews to their fate. A few days later Behring himself was in a gulf north of Cape St. Elias. He sent two boats to explore and to get fresh water. They found a deserted summer house, dried salmon, and a fire-drill.

Spaniards. The first recorded voyage by the Spaniards was in 1774 when Juan Perez in a ship named Santiago sailed from San Blas as far as the northern point of the Queen Charlotte Islands. On his return he anchored in a harbor later named Nootka. The next year the Spaniards, who were establishing themselves along the southern California Coast, sent three small vessels under the command of don Juan de Ayala to explore the coast northward. As pilot of one of these ships and chronicler of the expedition was don Francisco Antonio Maurella, whose name appears in connection with several such voyages. They stopped at Trinidad Bay, California, and then followed the coast to the neighborhood of Sitka, where they stopped to explore and take on wood and water. Returning because of scurvy they put in at a place they named Port Bucarelli, Lat. $57^{\circ} 17^{\prime}$, on the coast of Prince of Wales Island. A second expedition commanded by don de la Bodega, with Maurella second in command, spent May and June of 1779 in the same locality trading with the natives. 
Captain Cook. In 1778 Captain James Cook, on his third and last voyage, spent the greater part of April in Nootka Sound, where he secured a new mast and overhauled his ships Resolution and Discovery. Although Cook found among the Nootka, metals, including two silver spoons, obtained from the Spaniards in 1774, it was his opinion that they had never seen Europeans before. The account of the Nootka in the narrative of his voyage describes the houses, dress, and customs of the natives in considerable detail.

De la Perouse. Stimulated by Captain Cook's exploits under the English flag, France equipped two ships, the Boussole and Astrolabe, and sent them out to explore under J. T. C. de la Perouse. Leaving France in August 1785, the expedition reached Cooks Inlet in June 1786 by way of Cape Horn, the coast of Chile, and Easter Island. The ships were taken into a bay which la Perouse named Port des Francais, Lat. 58 $37^{\prime}$, where they remained several days. The Indians, who had summer villages for fishing in the bay, were constantly about the ship and the camp established on an island. Having lost two boat crews of men in the breakers at the entrance of the harbor, de la Perouse sailed down the coast, most of the time in thick weather, until he reached Monterey Bay, California.

Trading Ships. In 1786 English and American ships began visiting the Northwest Coast to secure furs, particularly sea-otter skins which they sold to the Chinese. Two ships from Bengal belonging to the East India Company under Captains Lorie and Guise reached Nootka on the 27th of June of that year. Captain Hanna arrived in August of the same year. A company organized in England to carry on the fur trade in the North Pacific, called the South Sea Company, sent out two ships, the King George in command of Captain 
Portlock and the Queen Charlotte commanded by George Dixon. The ships left England in August 1785 and spent three years in exploration and trade. Under George Dixon's name, a journal of the voyage was published which gives many interesting details concerning the Indians of the coast, many of whom had never before seen white men or their ships. In this account we have our first description of the Haida and Tlingit.

Exploring the coast and trading, Captain John Meares spent the summer of 1788 in Nootka Sound and southward as far as Shoal-water Bay, Washington. Under his direction during the summer, a schooner was built and launched at Nootka, and a trading post was established. The next year this settlement, as well as one of Meares' ships upon a return trip, were seized by a Spanish naval force which was ordered to hold the Pacific coast against the English.

Vancouver's Survey. Soon after, a systematic survey and charting of the coast was carried out for the English government by Captain George Vancouver, the account of whose voyage fills three large volumes. Much of the surveying work was done in small boats which were taken up many of the long inlets in order to distinguish the mainland from the islands. There are many incidental descriptions of the natives and their customs. We have in this work the first mention of the Bella Bella, perhaps also of the Bella Coola, and the Tsimshian. The Tlingit of the interior waters were often encountered by Vancouver's surveying parties. Vancouver was in unsuccessful negotiations for the transfer to England of the Nootka settlement seized by the Spaniards in 1789. He left England in 1791 and returned in 1795 spending the summers of $1792,3,4$, on the North Pacific Coast and the winters on the Sandwich Islands. 
Mackenzie. In the summer of 1793, Alexander Mackenzie crossed the continent of North America, having followed up the Peace River and its southern tributary he crossed over to the headwaters of the Bella Coola which he descended to its mouth. He continued his journey down Burke's Channel until he met natives who had seen Vancouver. In Mackenzie's account there are descriptions of the villages of the Bella Coola and of their fishing operations.

Fur Trade. It is not necessary to go into the details of the history of the fur-trading companies on the coast, since the subject has been fully treated in easily accessible books. The influence of these companies, however, on native life was very great. Astoria, established near the mouth: of the Columbia in 1811 by a company organized by John Jacob Astor, was turned over to the English Northwest Company in 1814 (?). For many years this company and the Hudson Bay Company, after the consolidation of the two, carried on their trade from Fort Vancouver, ninety miles above the mouth of the Columbia. In 1848, the territory having passed again into the control of the United States, the capital of the fur trade was transferred to Victoria on Vancouver Island.

Russians. The Alaskan coast was first visited by the Russians, as is mentioned above, in 1741. A settlement was made at Sitka in 1799 by Baranoff who built a fort and brought a large number of Aleuts to engage in sea-otter hunting. The Tlingit destroyed this fort in 1802 and a new one was built three miles south in 1804 . Sitka was visited that year and the next by Urey Lisiansky whose narrative is of considerable interest. The Russians continued the settlement at Sitka until the transfer of Alaska to the United States in 1867. 


\section{Chapter II. \\ MATERIAL CULTURE.}

\section{Houses.}

In many points of culture the Northwest Coast subdivides into three minor groups. The most consistently diverse are the Salish tribes in the south. Less definitely divergent are the Tlingit, Haida, and Tsimahian when contrasted with the Kwakiutl of the middle area.

Of the Salish. The houses of the south, including the Salish of the delta of the Fraser River and the Nootka of the west coast of Vancouver Island, are long and rectangular in ground-plan and usually with a very flat roof of only one slope. Those of the Kwakiutl and of the northern tribes are more nearly square varying considerably in size from twenty by thirty feet up to fifty by sixty. All of them have one peculiarity - that of an independent inner main framework and an outside covering or shell. The framework persists from year to year, even from generation to generation, while the planks of the outer shell may be removed and transported to other localities annually and pulled down and afterward replaced at the death of the house owner. I The framework of the southern houses consists of a double row of posts or punchions two or three feet wide and from five to eight inches in thickness. These punchions are paired along either side, and those of the two sides are separated according to the width of the house, from forty to sixty feet. Those forming the rear of the house are about ten feet high while those of the front are fifteen feet, providing a very gentle slope for the roof. Resting on these punchions are cross-beams having a length equal to the width of the house and a diameter of from twelve to twenty-two inches. Such a house is mentioned by George Gibbs, who says the framework was 
still standing at Fort Madison, Seattle, in 1855. The house had a total length of five hundred and twenty feet, a width of sixty feet, with seventy-four punchions and thirty-seven crossbeams. Such houses were enclosed with split planks, placed horizontally between pairs of vertical poles, lashed together with withes to hold them in place. The nearly flat roof was made with planks hollowed out with an adze and laid with the convex surfaces alternating up and down and overlapping like tile. A house of this sort was occupied by a large number of families, each with its separate fire. Ordinarily the space assigned to a family would be that included between two pairs of the separating punchions. These southern houses stand with the higher long side facing the beach. The entrance or entrances are ordinarily on the seaward side with an exit also in the rear. Raised platforms run along inside the house near the walls which are hung with mats. The various sections of the house are also separated during the winter season by suspended mats. Household property is stored on the side platforms where also sleeping places are provided. The household fires, instead of being in the center of each section, are built in one corner of it, to the front where the roof is highest. For potlatch occasions a high platform is provided outside at one end of the house from which property is distributed.

Of the Nootka. Nootka houses of this same general style are described by the earlier writers. The roofs, however, seem to have been in some cases in two sections instead of one. These houses, although large and entailing great labor in building, seem not to be so architecturally impressive as the houses of the north.

Of the Kwakiutl. The typical Kwakiutl houseframe consists first of two large posts fifteen to twenty feet long and two feet in diameter. These are set up six 
feet apart and about three feet back of what is to be the front line of the house. They are brought into an upright position by making the hole that is to receive them vertical at the front and by reënforcing it with a stout plank. An inclined plank is provided at the rear of the excavation. The base of

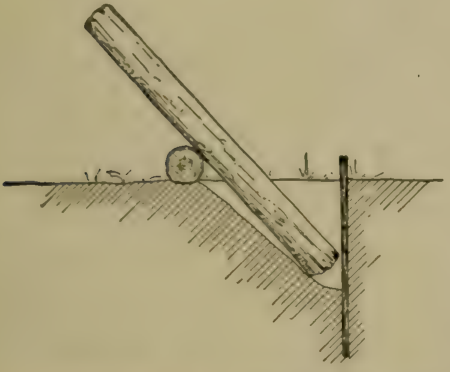

Method of Erecting House Posts. Kwakiutl: the post is placed in the hole and the other end raised by means of levers, a round log following down the incline to prevent the post from falling back. Across the top of these two posts a short beam is placed in semi-circular depressions provided for it. At the rear of the house two similar posts with the same spacing are erected, but ordinarily without the crossbeam. Next is provided a pair of horizontal beams as long as the house is to be deep, often fifty or sixty feet in length and eighteen inches in diameter. They are nicely adzed, being slightly fluted, with the adze marks left unobliterated for their decorative effect.

One of the methods of raising these beams is to place a log sloping from the top of one of the uprights toward what is to be the side of the house. Up this slope one end of the large beam is slid by means of levers and secured in place by a pole of proper length while the lever is reset for the next lifting. A guard is fastened to the top of the post to prevent the beam from slipping over when it comes into place. The other end of the post is brought up in a similar manner. Another method, perhaps not so old, but simple and effective, is to provide a cribwork in the center over which the long beam is balanced. 


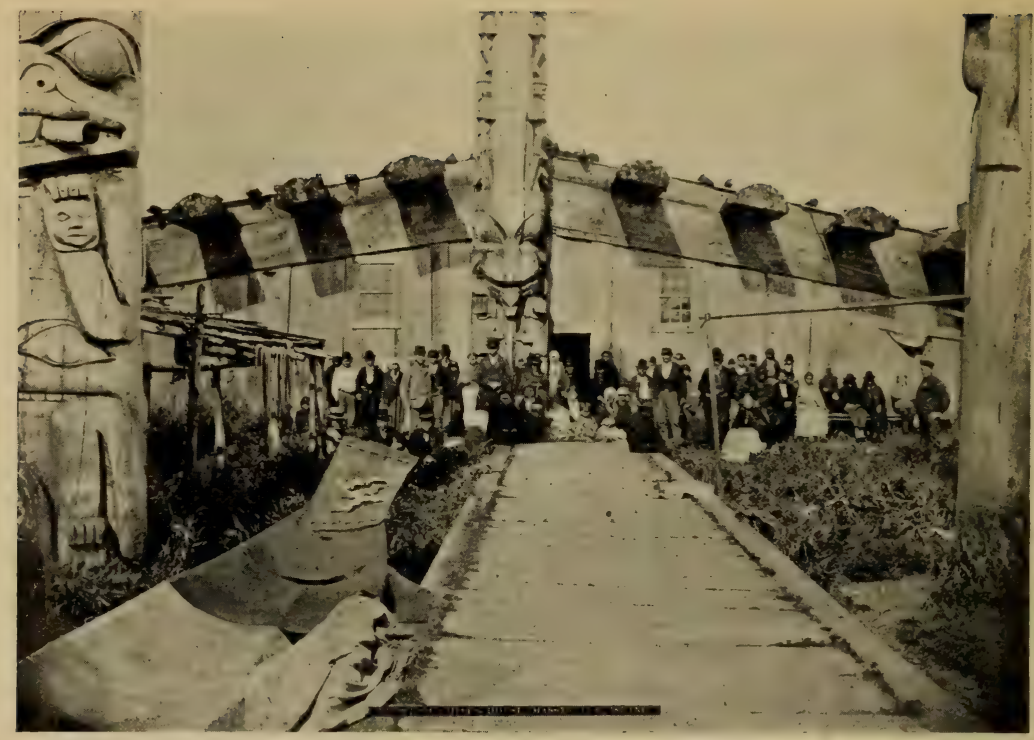

House with Modified Front. Haida.

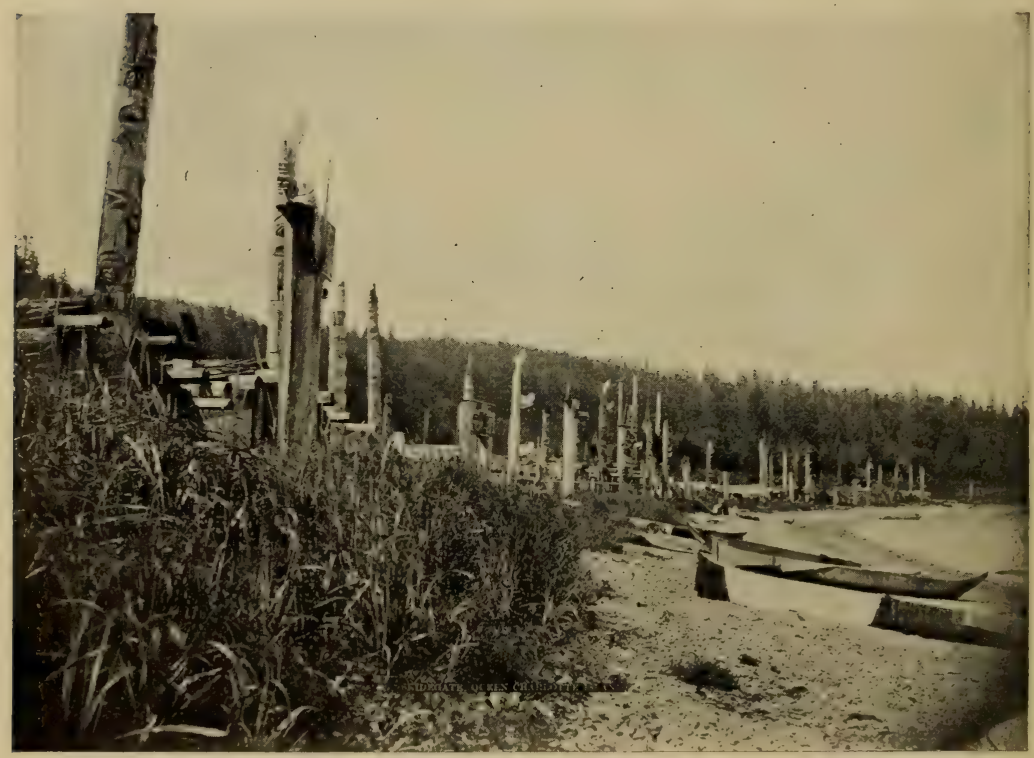

Skidegate Village on Queen Charlotte Islands. Haida. 
When one end of the beam is pulled down toward the ground there is room to insert another block at the raised end. The beam is next see-sawed and the blocking placed at the other end. In this manner the beam is easily raised to the required height.

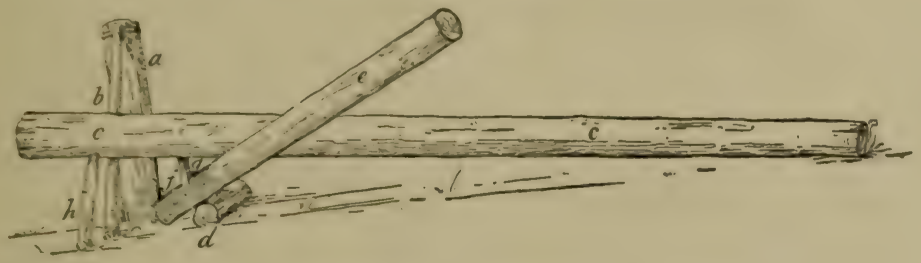

Method of Raising House_Beams. Kwakiutl.

Posts or punchions of a less size are provided at the four corners to hold up the plates at the eaves of the house. Rows of posts are also put up at each end which carry additional longitudinal roof beams. In earlier times the house was closed in with thick planks, split and adzed, placed horizontally along the four sides and lapping over each other slightly to shed the water. They were secured in place between pairs of poles and lashed with cedar withes. Similar planks ran from the eaves to the ridge so that the cracks between the first layer were covered by a second layer. At the present time planks are ordinarily placed vertically instead of horizontally. Before they are put in position a bank of earth about three feet high is placed around the house. In the front, this bank is retained by a thick plank the upper end of which is grooved to receive the lower end of the planks forming the end wall. Their upper ends are held in place by lashing them to the crossbeams of the end and the first rafters of the roof frame. The planks of the side walls and back are embedded in the earthern banks. 


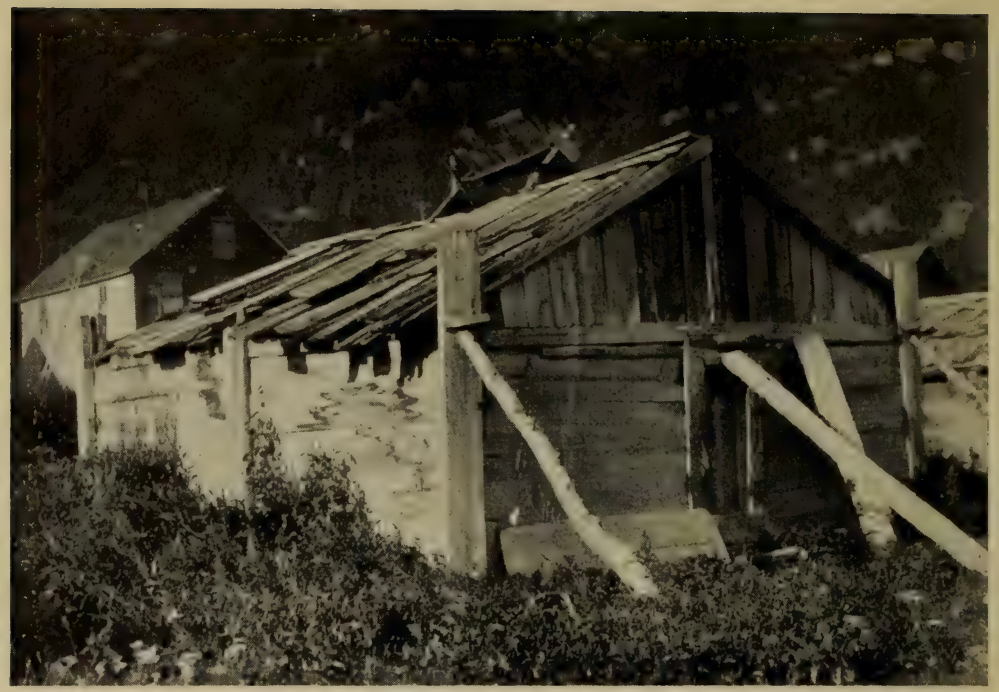

House at Klukwan Village. Tlingit.

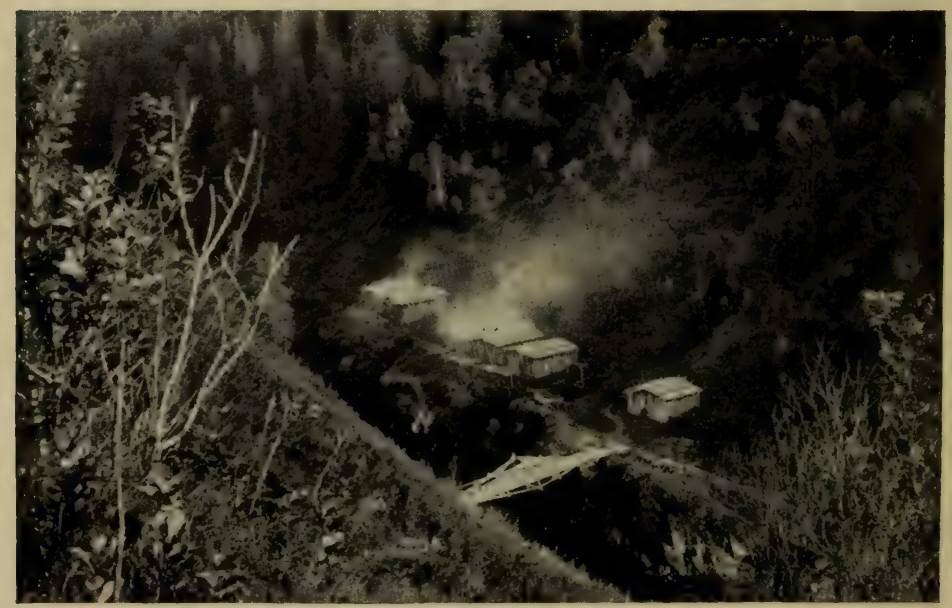

Fishing Village at Kisgagas on a Tributary of the Skeena River, British Columbia. Photo. by C. M. Barbeau. 
The ground plan of a Kwakiutl house is laid out with a cedar rope, a line being first run from the middle of the front to the middle of the back. By doubling the rope the distance from these middle points to the corners is easily measured. A rectangle is then secured by making the distances equal from each corner to the middle of the opposite side.

These houses stand with the gable end toward the sea and have a door of moderate height near the middle. At the rear end of the house, the more desirable location, the owner has sleeping quarters for his family. These are generally enclosed by a wall of planks. At the rear on the right is often a similar enclosure for the safekeeping of ceremonial objects serving also as a dressing room when ceremonies are in progress. Along the sides are the sleeping places of the other inmates. Each house fire is in part partitioned off, by means of mats, and has a rack above it for the storage and drying of fish.

Chilkat Houses. The houses of the north are ordinarily not so large as those of the Kwakiutl. At Klukwan, a Chilkat village, there are rectangular houses, the longitudinal wall planks of which fit into grooves provided in the corner posts and in an additional post placed midway of the sides.

The houses of some of the chiefs seem to have been provided with a series of earthern banks inside, forming a terrace. Many of the northern houses have carved poles placed against the middle of the front end with the house entrance through an opening cut in them.

Platforms. These houses stand in rows far enough back from the sea for a wide street to run along in front of them. On the seaward side of this street resting on piles are platforms, upon which during the fall and spring much time is spent, either in work or pleasure. 


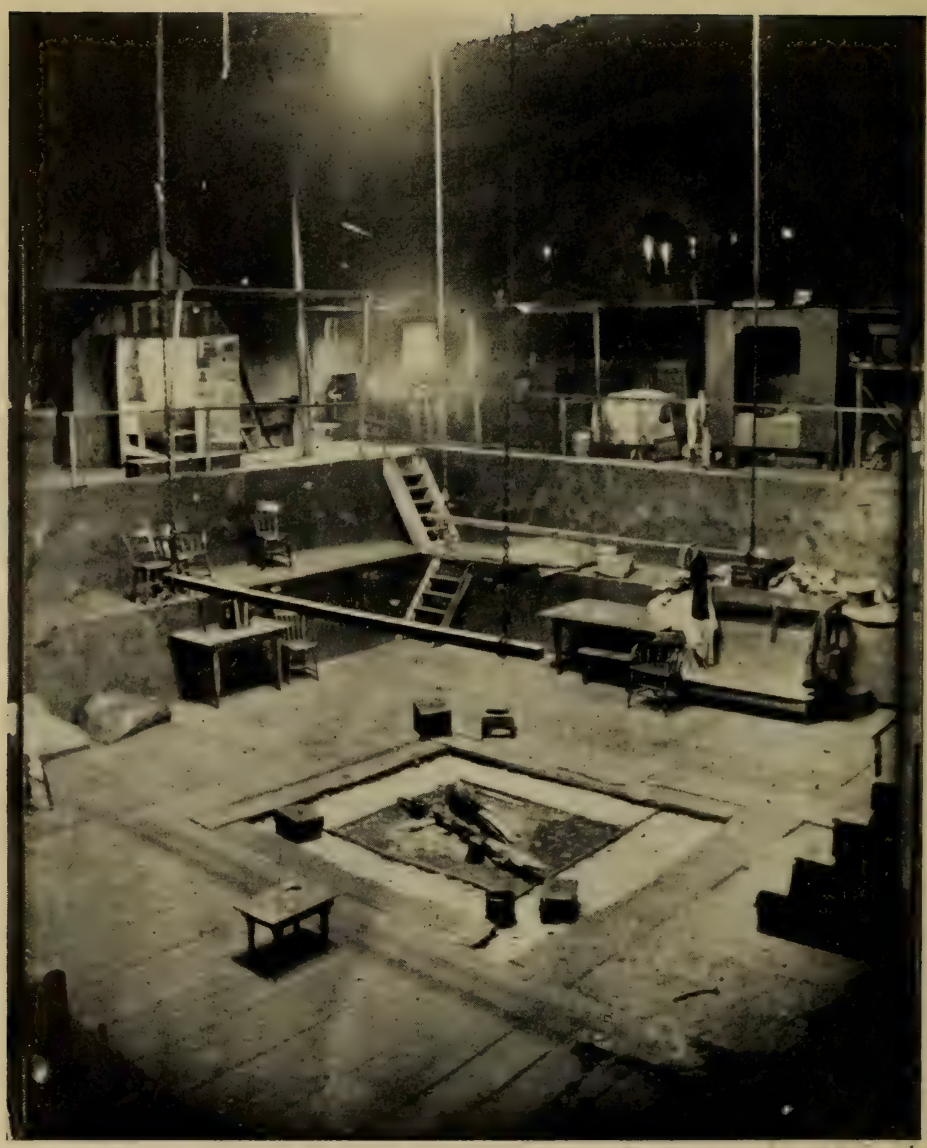

Interior of House Showing two Terraces with Fire below and Sleeping Compartments above. House of Chief Weir at Masset, a Haida Village. 
Frequently a second or a third row of houses stands back of the first in irregular order.

Cooperatively Built. It should be clear from the above description that houses of such size cannot be built by the labor of an individual. A man who plans to erect a house accumulates provisions and property until he feels justified in making a beginning. He then invites his friends and connections to assist. He may be able to provide and erect only the four main posts before his supplies are exhausted. In that case he accumulates again until he is able to continue the work. The men who assist him must be fed and considerable distributions of property must be made, not only to those who assist, but to others as well. Houses of this character are occupied during the winter and early spring. When the salmon begin to run in the streams the planks are sometimes removed from the house, placed on canoes, and transported to the summer village, to be brought back again and replaced in the fall.

\section{Canoes.}

Types. Travel on the Northwest Coast is almost entirely by water. Formerly, cedar canoes of varying sizes and shapes were employed, but at the present time gasolene-driven vessels are in general use. Geographically, two types of canoes can be distinguished: a northern one with both the bow and the stern raised and projecting over the water; and a southern type, used by the Nootka and Salish, with a vertical stern and projecting bow. These canoes with projecting bows are for use particularly in ocean waters where waves of considerable size are likely to be encountered. For use in rivers "shovel-nose" canoes are employed. They have wide bows and sterns without much over-hanging 
and are more easily poled than are the sharp-bowed canoes.

Sizes. In size, the canoes vary from one, adapted to the use of two or three men, about sixteen feet in length, to the great sea-going canoes sixty feet in length and capable of carrying fifty or sixty men. A specimen in the Museum is sixty-four feet long and eight feet wide. With such canoes the Haida visit as far south as Puget Sound, seven or eight hundred miles from their homes.

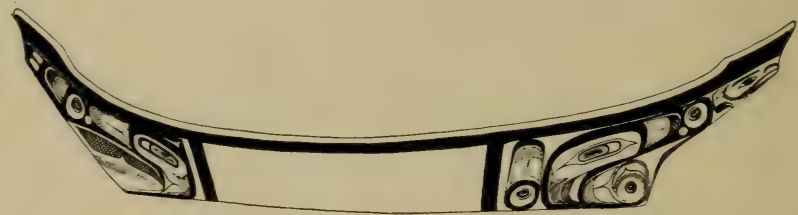

The Northern Type of Canoe with Projecting Bow and Stern. Haida.

Methods of Propelling. These canoes are propelled with paddles having a lanceolate blade and a crutchlike handle. The steersman has a paddle more pointed at the end and more easily turned in the water in controlling the direction of the craft. Canoes were also sometimes sailed perhaps even before the coast was visited by Europeans. These sails were made either of wood or of matting. A wooden specimen in the $\mathrm{Mu}-$ seum is about nine feet square and five-eighths of an inch thick, made of several pieces joined by sewing with spruce root. To prevent splitting, the ends of the sail are reënforced by strips with the grain running in the other direction. Such sails were employed particularly when two canoes were lashed together and covered with house planks. If the wind were from the stern the sail was leaned up against a pile of boxes, or possibly against 
a short mast and the canoes were driven before the wind. Mats were also employed with a mast and a yard. In very rough weather the Nootka, at least, were accustomed to attach sealskin floats to gunwales of the canoes to steady them.

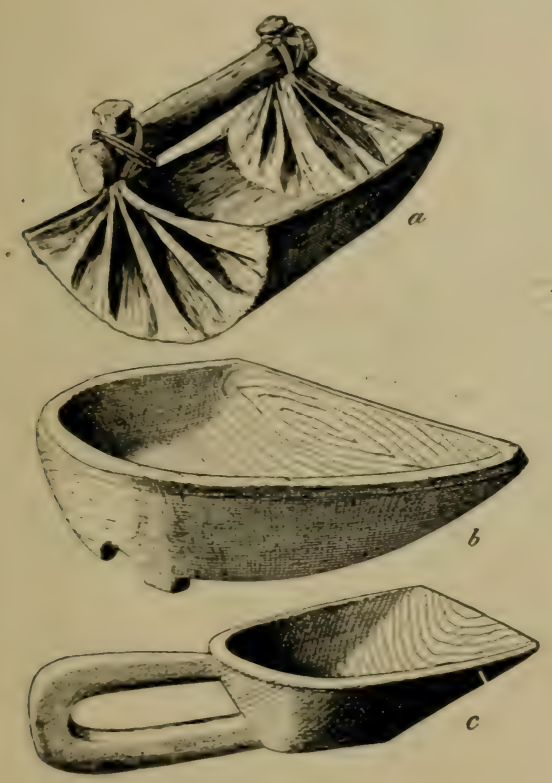

Bailers for Canoes. Kiwakiutl.
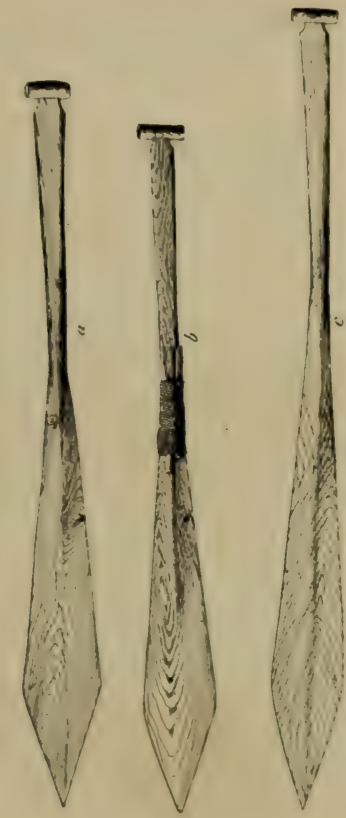

Paddles: c, for stearing.

\section{WORK IN WOOD.}

The Northwest Coast peoples excel in woodwork, and this is undoubtedly due, in some measure, to abundant timber very easily worked; but fundamentally it is the result of their being turned, by some unknown circumstances, to wood for supplying their needs for houses, canoes, household dishes, and storage receptacles. In other regions timber was also abundant; 
the first growth of white pine of the Eastern Woodlands was little, if at all, less satisfactory than the two cedars of the Pacific Coast. The Indians of the east, however, employed birchbark for houses, canoes, and household vessels. Woodwork as it developed on the Northwest Coast took on some unique features an example of which is the bending of boards to facilitate box-making.

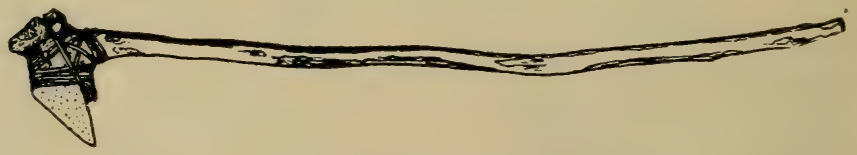

Long-handled Adze.

Tools. The woodworking tools are of polished stone, shell, antler, and bone. The Northwest people curiously enough did not make stone tools by flaking. They have no axes, but two forms of adzes. One of these has the blade attached to a piece of wood from the trunk of a tree with a limb, forming an acute angle with it, furnishing a handle about two feet long. The other kind has an oval opening for the hand with the blade bound to the under side in the same plane. The blades were formerly of shell or bone. Chisels have wooden handles and, before metals were common, had stone or bone blades.

Felling. It is said that in times before European influence had been felt, trees were not felled by the Kwakiutl. Ordinarily, it was possible to find a suitable tree which had blown down. In case such trees were not available, slabs were split from a standing live tree. To accomplish this a scarf was cut with a stone adze or chisel at the base of the tree at the side that promised the best material. In this hole fire was placed and controlled by keeping the tree wet above. A workman then went up the tree to the desired height and standing on the limbs of a neighboring tree made two cuts about 
18 inches apart. The wood between these was wedged out and then wedges were driven in splitting off a long slab of the desired thickness. It would appear that the Nootka were accustomed to fell trees even before the appearance of the Europeans. It seemed to be the general practice along the Northwest Coast to explore the tree first by chiseling a hole into the center to make certain it was entirely sound.

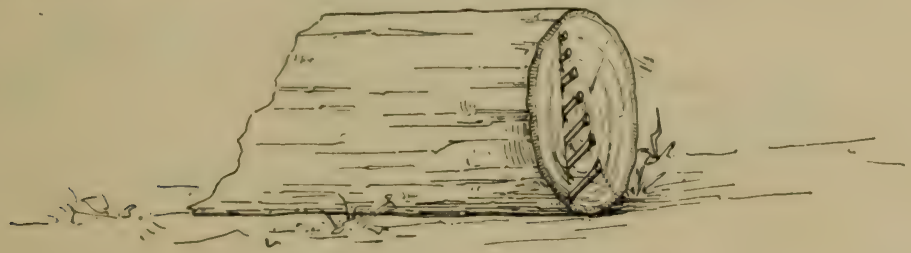

Set of Seven Wedges in the End of a Log.

Splitting Planks. Trees already on the ground, either selected from the ocean drift or wind falls, or those chopped down, were severed at the desired place by building a fire on top of them into which stones were placed to localize the heat. Water applied on either side of the fire prevented its spreading beyond the desired limits. The log so cut off was split by means of wedges, among the Kwakiutl always seven in number and of graduated lengths, set in a row across the end. The longest wedge was the farthest from the workman. With a stone hand-hammer he tapped these wedges in succession until the splitting was completed. The direction of the split along the length of the log was controlled somewhat by manipulating the internal stresses, accomplished by either loading the log with stones, or by rolling it until its own weight became effective. Several planks of the desired thickness could be secured in this way from the same log. For some purposes planks taken through the heart of the tree, so 
that the grain was radial, were preferred; while for other uses the outside pieces, with the grain running across the?width of the plank, were more desired. The split

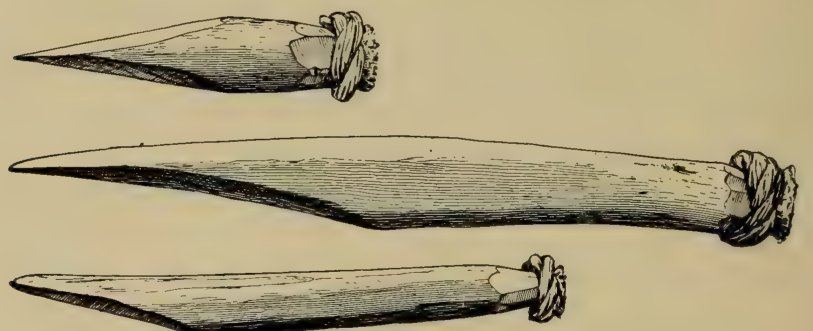

Wedges Used for Splitting Boards from Logs. Kwakiutl.
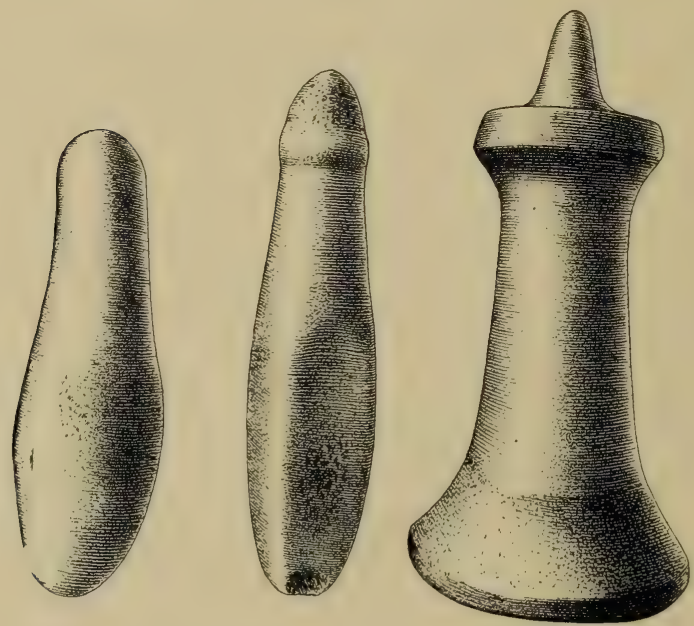

Hand Hammers: Left for Lateral Blows (Quinault); Right for Downward Blows (Kwakiutl).

planks were afterward reduced to the required thinness and smoothness by the means of chisels and adzes. First the chisel was held at an angle and driven into the 
plank, and then brought down parallel with it and tapped with a hammer, splitting off a chip, regulated to about four inches in length by the previous downward cut. To further smooth the work a hand adze was employed. The adzing was either carried along the length of the plank with the grain, giving a fluted appearance; or across its width, giving the effect of texture. If a
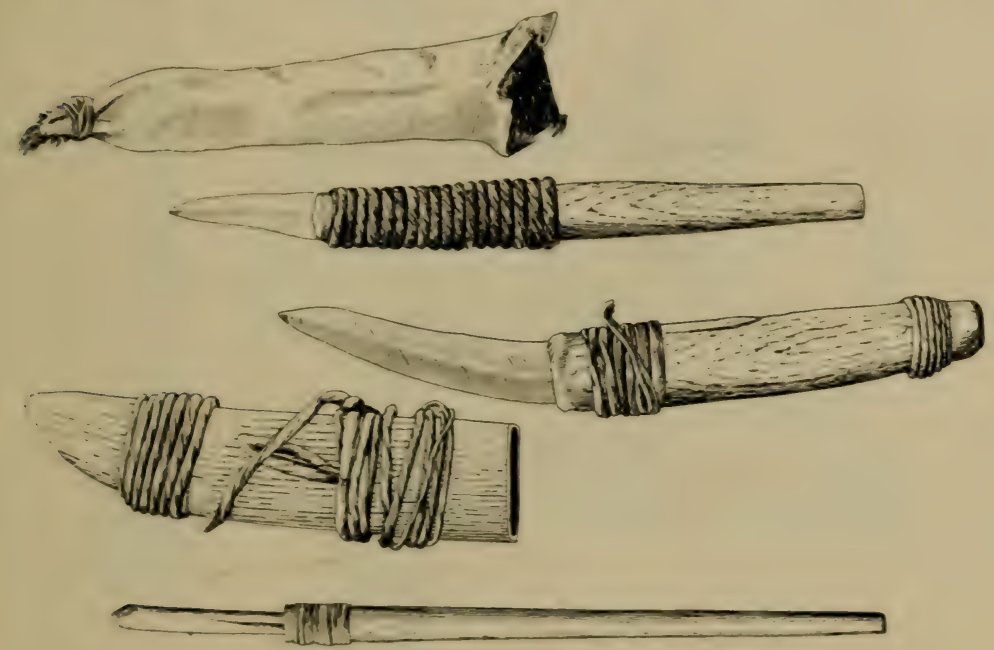

Carving Knives. Drill with Bone Point. Kwakiutl.

perfectly smooth surface was desired, grit stones and shark's skin were employed to remove the adze marks.

Bending Wood. Wood is successfully bent for several purposes. The making of boxes is a particularly ingenious process. A board split through the heart of the tree, and of a length sufficient to reach around the perimeter of the proposed box, is worked down with a chisel and an adze to a uniform thickness. It is carefully measured with cedar measuring sticks made for the particular purpose, and kerfs are then cut, as shown 
in the illustration, with the necessary bevel on one side. When the board is ready, ditches are dug into the earthern floor of the house, spaced to correspond to the kerfs in the board, which is laid down and hot stones are placed below and above the kerfs. Eel grass is then
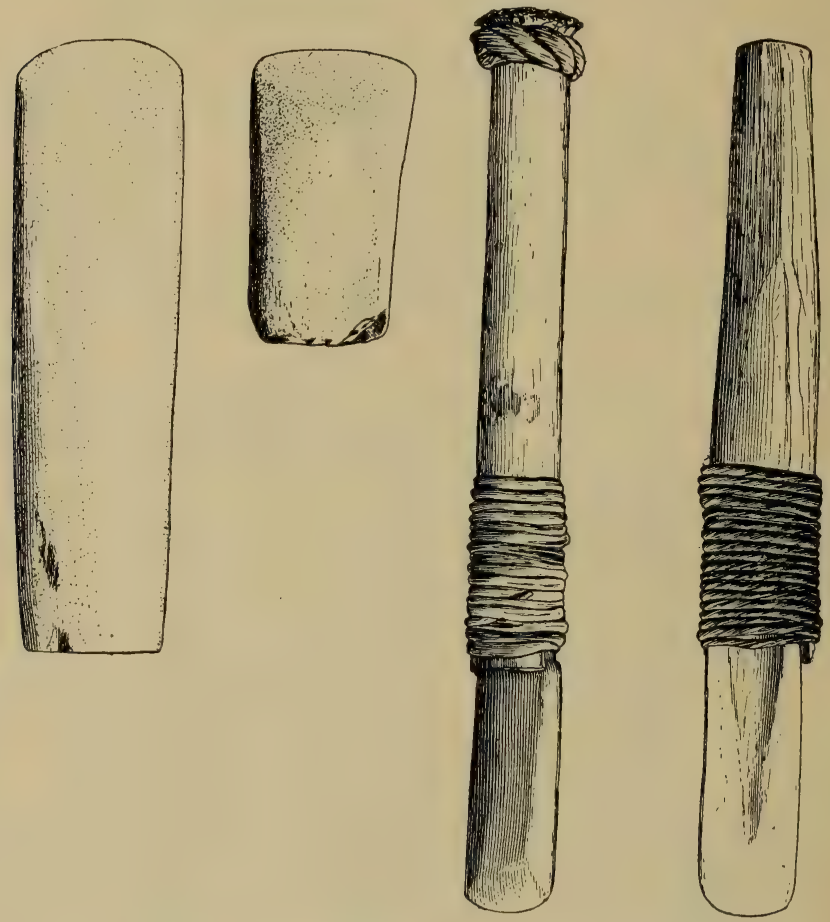

Chisels with Bone Blades. Kwakiutl.

spread over the stones, water poured on, and mats spread over the whole board. When the steam so generated has done its work, clamps of wood, provided for the purpose, are slipped on the board and brought to the edge of the kerf while the board is bent to a right angle. 
When this has been done three times the sides of a square or rectangular box have been provided. The board is held in this position by a rope of cedar withes, until diagonal holes have been made with a drill through the corner, where the ends of the board meet. Wooden pegs are driven into these holes, or spruce root is passed through them to sew the ends together. A bottom is provided and a groove cut around its edges into which

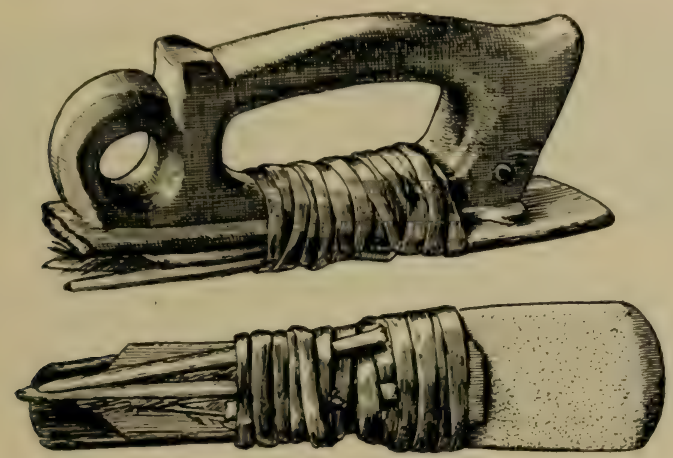

Hand Adze with Blade of Stone. Nootka.

the sides fit. This bottom is attached by means of pegging or sewing. Many of the boxes are also provided with covers; those of the Kwakiutl having a piece projecting upward along one side.

Boxes of this sort were used for cooking food by means of hot stones, for water vessels, and for the storage of all kinds of small property. Finally when death occurred one of the larger boxes was used as a coffin into which the body was placed by folding it violently, if necessary.

Steaming is also resorted to in producing the abruptly curved fish-hooks used for halibut and cod. Those of 
the south are from the knots where the limbs joined a fir tree, worked down to the desired size and then placed inside a kelp stem. This is buried over night in the hot ashes of the fire. The next morning the pieces are bent to the desired curve, and forced into a wooden mold, made by digging out a groove of the proper curvature in the surface of a board. When the hooks have become set in this mold they are removed, warmed by the fire,

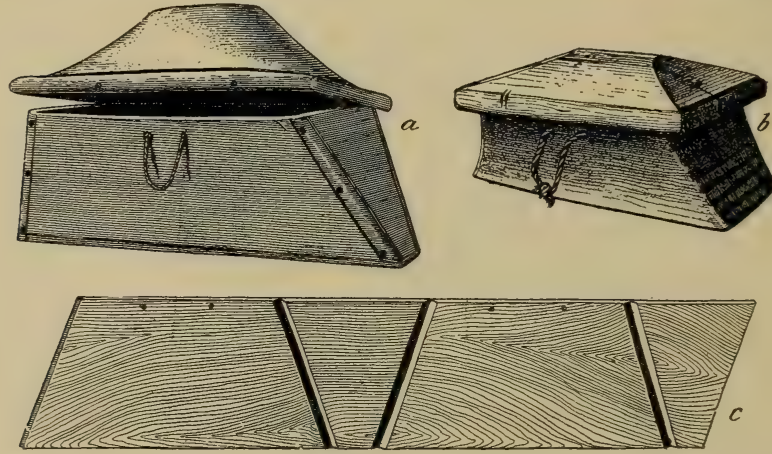

Hunter's Boxes. Board Cut for Folding to Make Such a Box. Kwakiutl.

rubbed with tallow, and then returned to the mold. The tallow is said to prevent their straightening out at a later time.

Dugout Dishes. Food-serving dishes are usually made of alder wood; the western species being a tree of considerable size. When a piece of suitable length has been split out, the side nearer the heart of the tree is adzed and shaped for the bottom of the vessel; and the outer side, nearest to the bark, excavated until the sides of the dish are of the required thinness. For feasts very large vessels of this sort are provided often in the form of a person or an animal. 

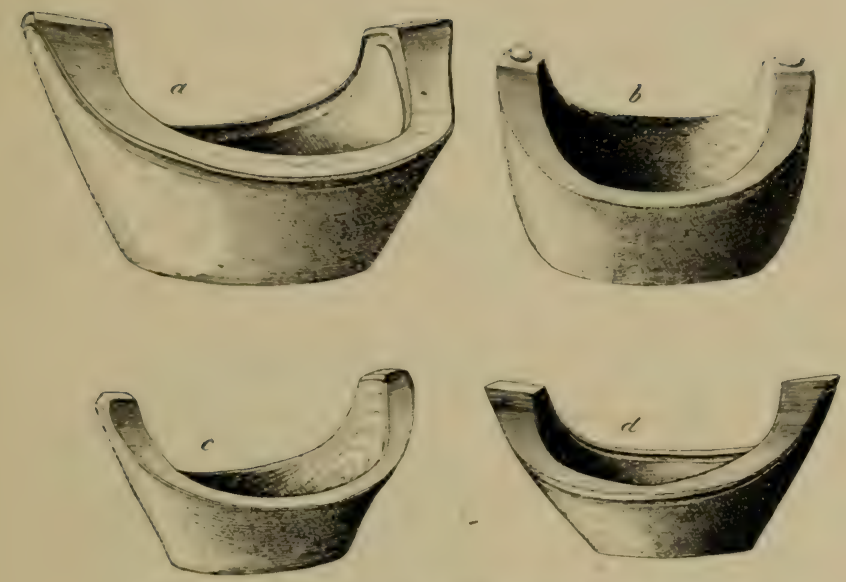

Oil Dishes, Dug out of Alder Wood. Kwakiutl.
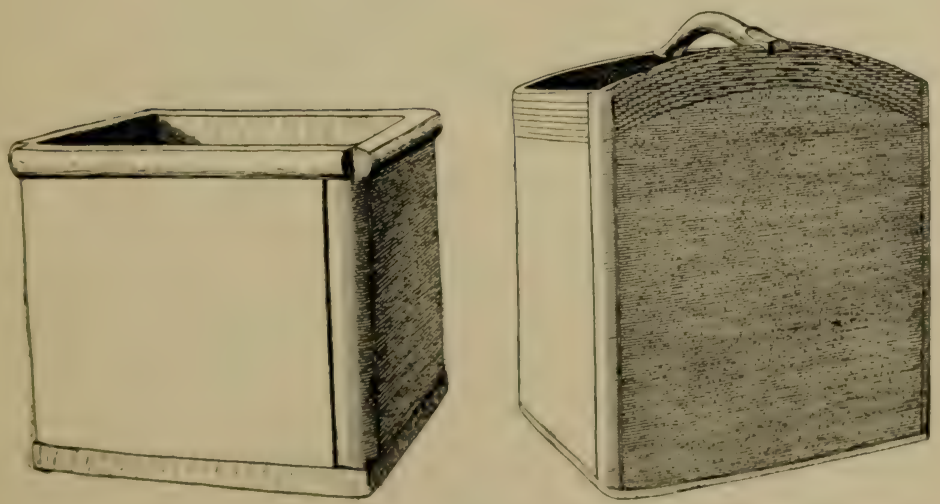

Wooden Vessels: Ifeft, Irinal; Right, Water Bucket. Kwakiutl. 
Canoe-making. The making of a canoe with primitive tools was a formidable undertaking. When a log of the proper length and size had been secured, the outside was adzed to the approximate shape desired. The inside was excavated, partly by adzing, and partly by the use of fire which was allowed to char the wood slightly. The charred portion was easily removed, and the opera-

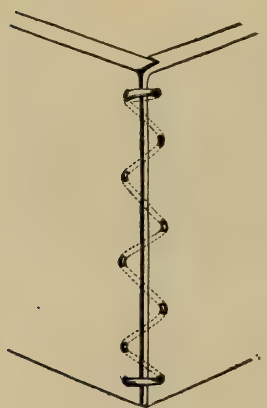

The Joined Corner of Box with Stitching Indicated. Kwakiutl.

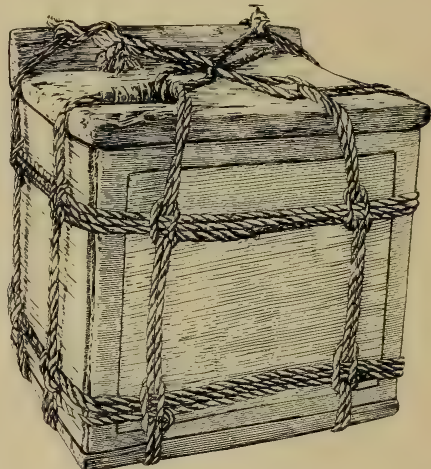

Box with Projection on Lid. Kwakiutl.

tion repeated. The thickness of the sides was judged, sometimes by running the hands over the outside and inside and noting unevennesses; but, at times, holes through the sides were bored, measurements taken, and the holes plugged. The canoe was given a greater width than the diameter of the tree from which it was made, by filling it partly full of water which was heated by dropping in hot stones. Cross-pieces were then forced in to spread the canoe which was later held to that shape by thwarts sewed to the upper edges of the boat. The stern and bow pieces and, sometimes even the gunwales, were made of separate pieces, and sewed on. 
Seving Wood. The joining of wood by means of sewing must be considered one of the special accomplishments of the Northwest Coast people. The conception may have been taken over from birchbark work of the sort done by the interior tribes, but if so, great skill is shown in the application of this process to woodwork. The threads of spruce root are often concealed in deep grooves, so as to be unnoticed unless sought for. Mending of cracks in canoes

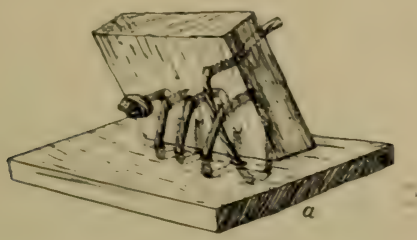
and other objects is done by an ingenious use of sewing.

Their superiority in woodwork is further shown by the large tim-

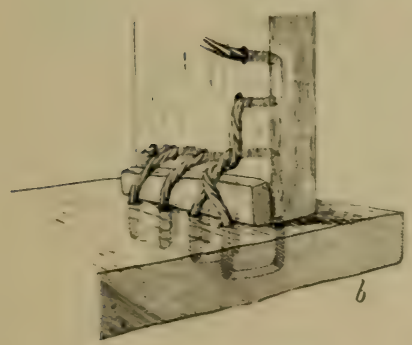

Method of Joining Boards by sewing. Iiwakiutl. bers and planks which were successfully made and placed in position in house building; by their ingenuity displayed in controlling the cleavage of wood, by regulating the internal stress; in bending fish hooks and box sides; and by the technical skill displayed in the adzing, and securing by sewing of the large wooden sails formerly used on the canoes.

The houses, canoes, vessels for cooking, serving, and storing of food, and the carved poles, are very much in evidence and impress the visitor with the great importance of woodwork in the lives of these people. 


\section{Textile Arts.}

The textiles of the northwest consist of nets, mats, baskets, and blankets. As in other phases of life, tribes of the southern and northern portions of the territory are to be differentiated from those of the middle sections. In the north, particularly among the Tlingit, basketry and blanket-weaving have a high and very special development.

Nets. Nets are made of nettle fibre. The nettles are cut in October and dried for five or six days out of doors and then over the house fire. When the stems are thoroughly dry they are broken over a bear's

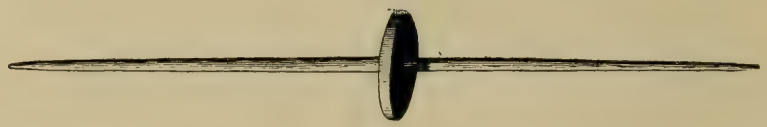

Spindle Used for Nettle Fibre. Kwakiutl.

rib and the fibres combed out. The women spin the nettle twine with the aid of a spindle, having the raw material draped over a stake, and the string while in process of spinning coiled in a box of sand. The first strands are combined and recombined to give two and four-ply twine, according to the size and strength required. The net is made by tying the twine in meshes of uniform size which is determined by the use of a mesh measuring stick. The long olachen nets are conical in shape with a mouth opening of six feet in diameter, tapering to ten inches at the smaller end. The size of twine is increased progressively from the smaller toward the larger end.

Mat Making. The mats and the methods of manufacture are quite uniform for the entire area. The material is either the inner bark of the red cedar, Thuja gigantea, or the much softer bark of the yellow cedar. 
The red cedar bark is divided into strips of appropriate thinness and width and then woven either in a plain checker, or diagonally in a twill. While in progress, the work is suspended from a batten placed horizontally at a height convenient for the woman to work when seated. The warp strands are draped over this batten so that they hang evenly on either side. In order to secure them in position two strands of bark are first twined
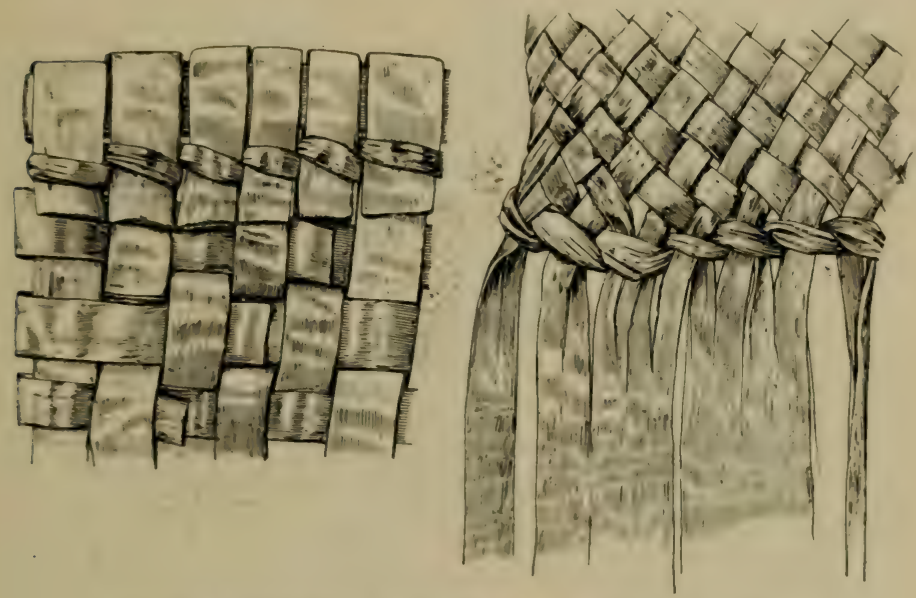

Details of Square and Diagonal Mat Weaving. Kwakiutl.

once across. If the weaving is to be plain checker a woof strand of the same width as the warp is carried acrosis horizontally passing alternately over and under the warp strands. In diagonal weaving the warp and woof strands which are identical are interlaced at right angles to each other. The worker gathers up these strands in bunches, and has those not in use tied up out of the way. A dish of water is always at hand to keep the material sufficiently damp to be pliable. 
In the southern portion of the country along the Fraser River reeds are available for the making of mats. These are fastened together by passing a string directly through them at each end and in the middle. The

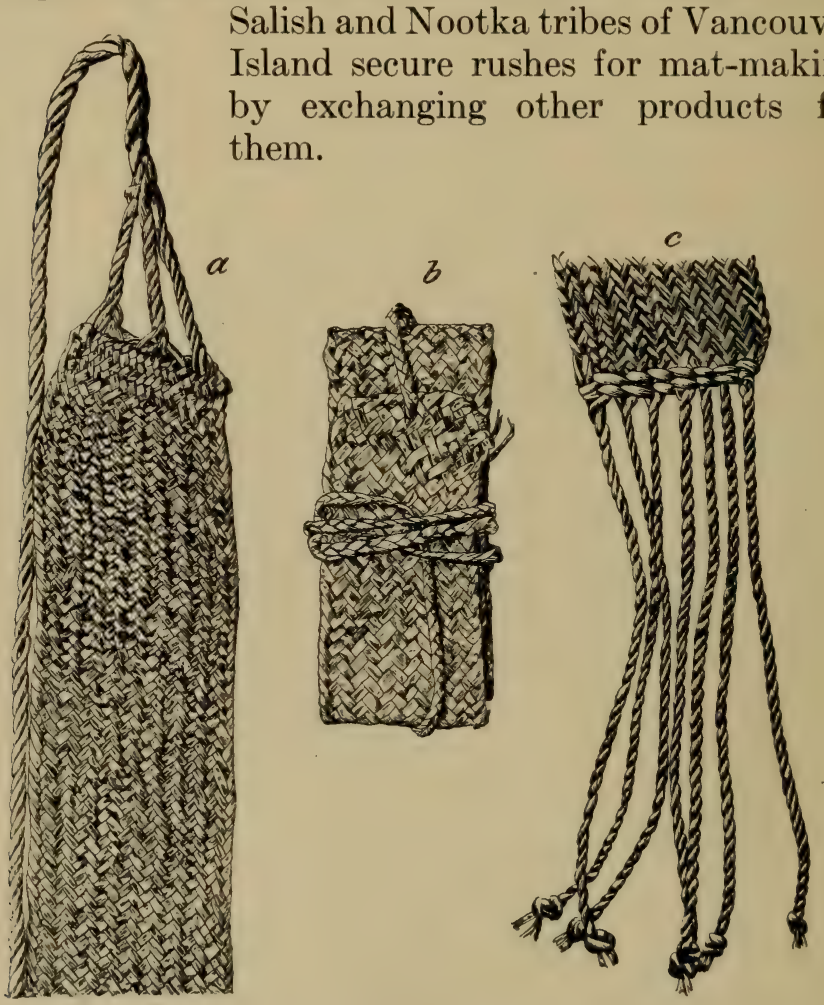

Twilled Belts of Cedar Bark. Kwakiutl.

Carrying straps and narrow bands are also made with diagonal plaiting, the strands being bent over at the edges and continuing at right angles to their previous course. But little decoration is attempted in work of this sort, but darker strands are sometimes introduced 
producing lines and bands. The direction of the twilling is also sometimes changed so that lines forming right angles are produced. Baskets and bags are made of similar material and by the same method. When a square bottom has been plaited it is suspended by strings from the four corners so that the bottom is in a

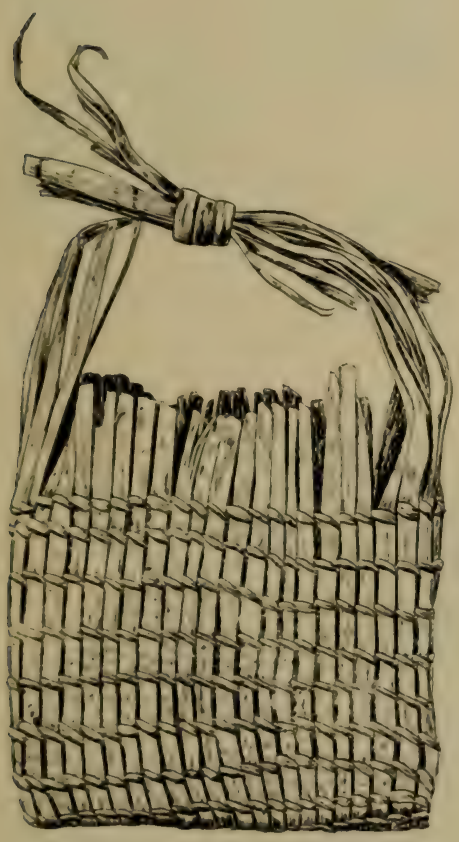

Bag, Illustrating Open-t wining. Kwakiutl.

horizontal position and the ends of the strands hang down. The weaving then proceeds around the basket until the walls are of the required height.

Basketry. The prevailing method of basketmaking is the bird-cage weave. Warp strands, usually of split spruce root, are interwoven in checker work to form the bottom and are then continued up the sides where they serve only as a warp. The woof consists of two sets of smaller and more pliable root material. One of these is placed horizontally along the outside of the basket and the second one is wrapped around the first between each warp strand and then is carried outside the warp strand diagonally, firmly binding the two together. Such baskets are of open-work and the woof strands are -paced so as to give the desired openness. A basket of very pleasing appearance is produced by arranging 

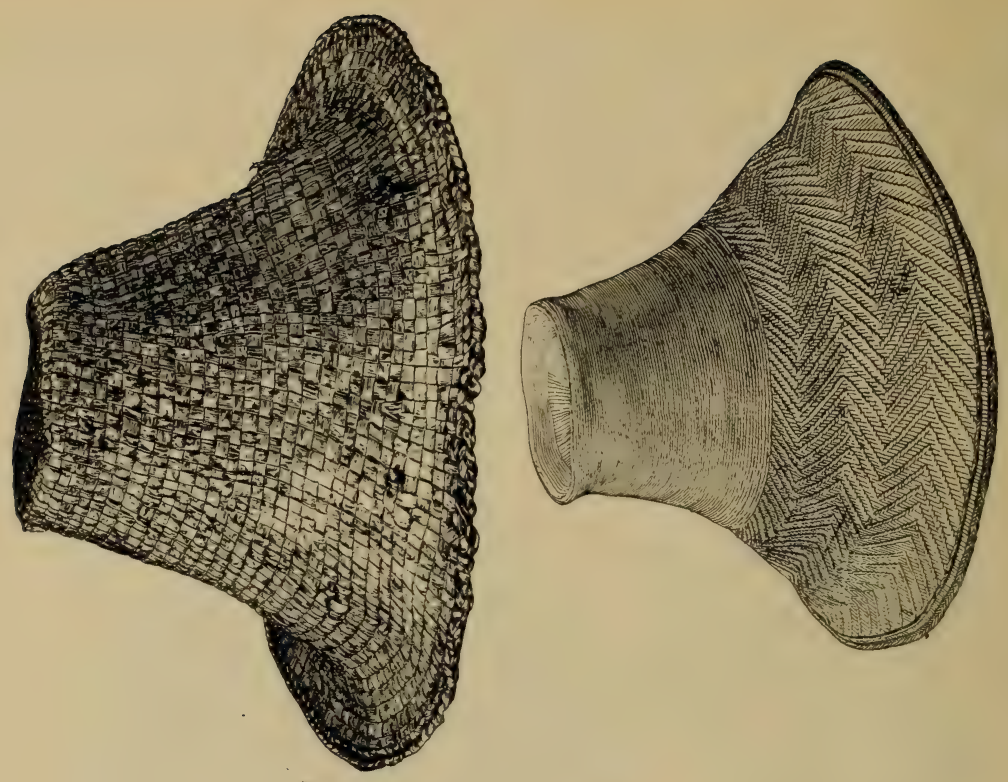

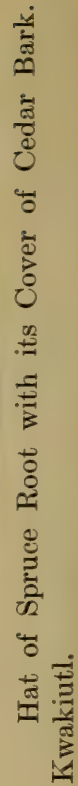
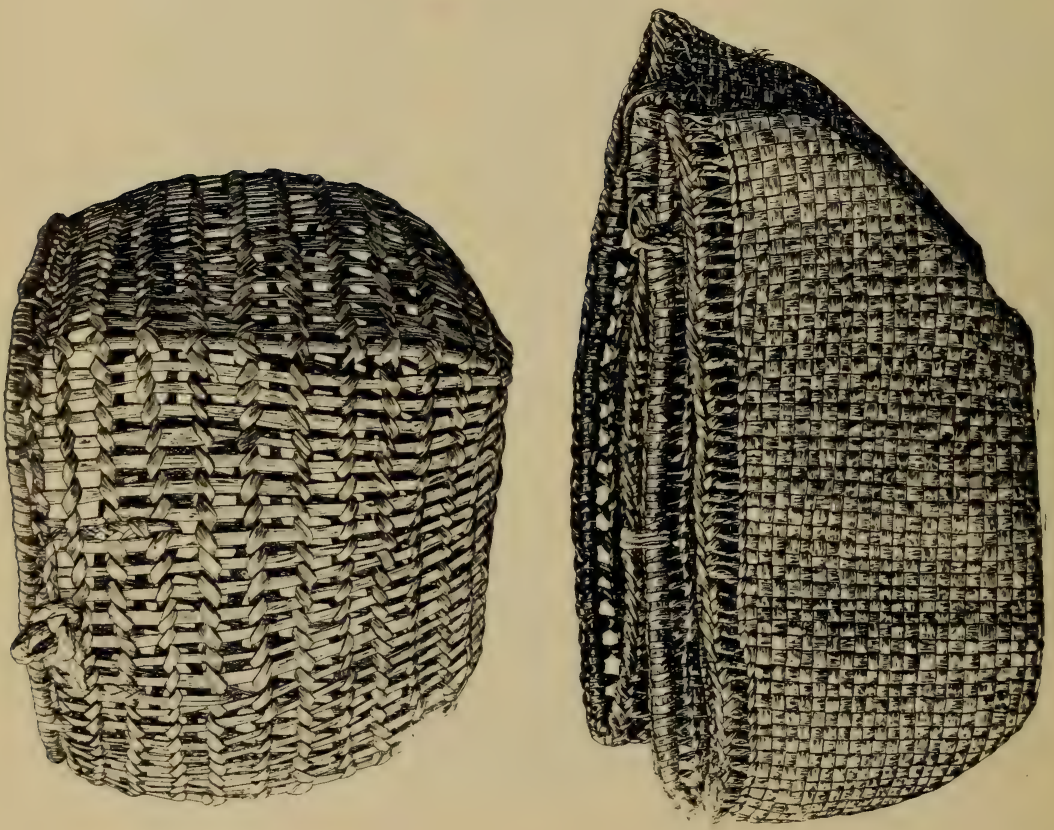

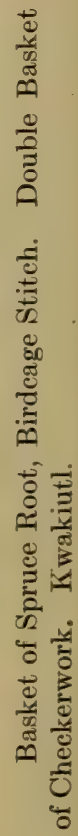



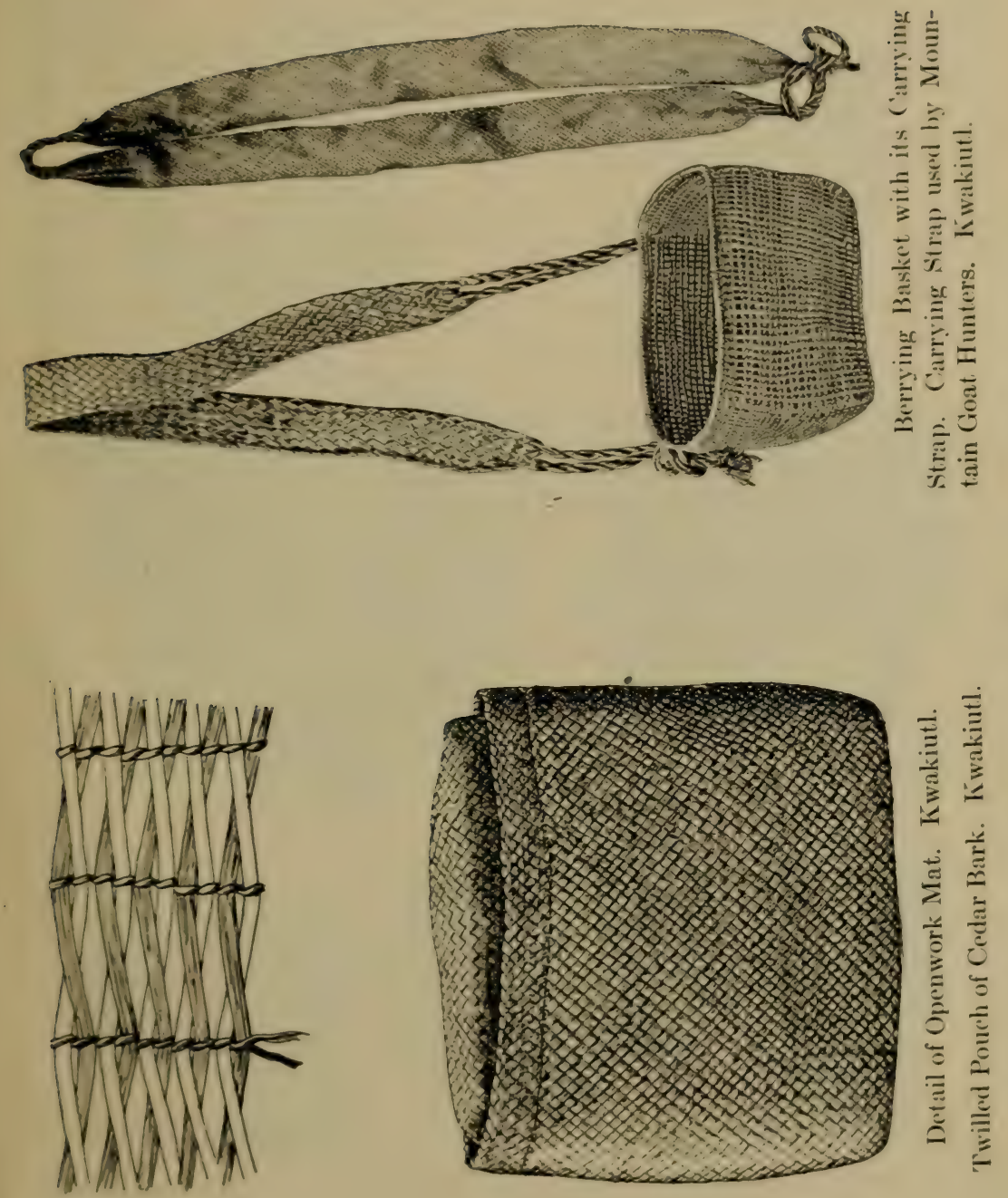

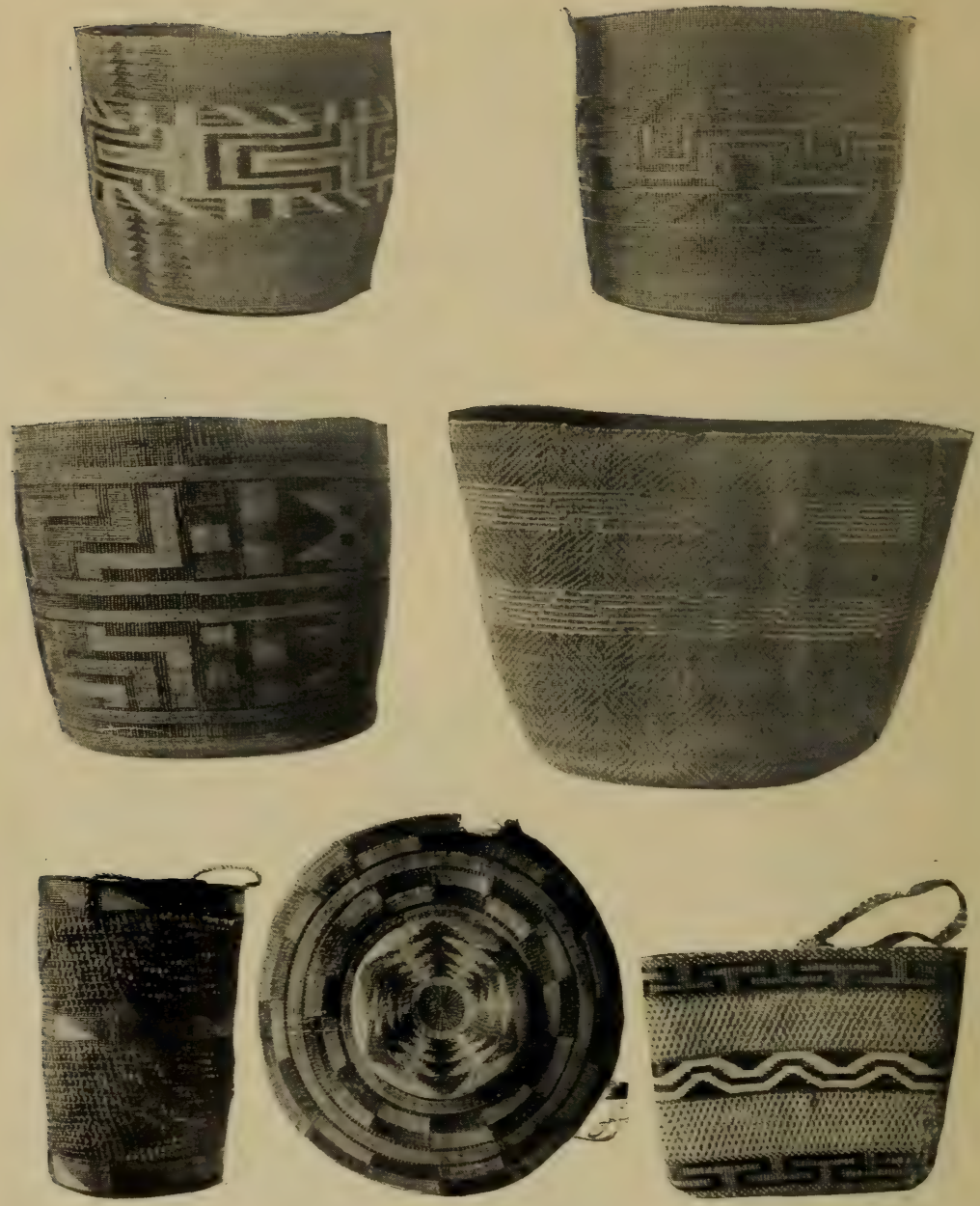

Tlingit Basketry. 
the cedar bark warp strands so that they run diagonally up the basket in opposite directions so as to cross. Two inner strands of the same material are twined around horizontally engaging these warp strands.

Tlingit Baskiets. The northern Tlingit have developed a great variety of ornamented baskets of twined weave. There are two other considerable regions of

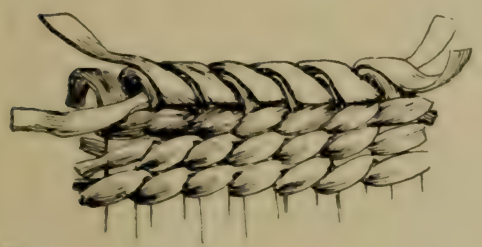
twined weaving in North America; one in Oregon and northern California, and another along the Aleutian Islands. The material employed by the Tlingit in constructing these baskets is ob-

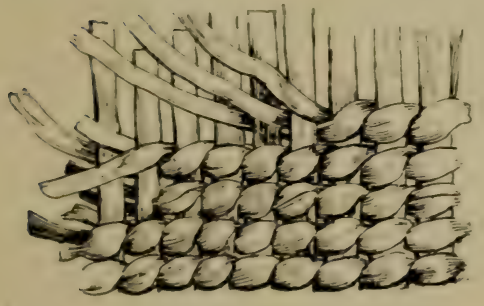

Details of Tlingit Basketry: Top, Two-strand Twining; Bottom, Three-strand Twining. tained from the smaller roots of the Sitka spruce. As soon as the roots have been gathered the bark is removed by carefully roasting them and pulling them through the opening between the two parts of a split stick. The roots are then divided into the outer portions, smooth and shiny, for the woof; and the inner layers for the warp; the hearts being discarded. These roots are gathered in the spring or summer and seasoned until winter which is the proper time for basket-making. Three kinds of twining are employed: plain two-strand twining; three-strand twining when strength is desired at the turn of the basket where the walls begin; and two-strand twining over pairs of warp strands, which in the succeeding rows are regrouped giving a diagonal effect. 
The ornamentation is produced by over-laying the woof with the stems of grass or of the maiden-hair fern. The grass material is either bleached and used white or dyed. A black dye is secured by employing the mud of sulpher springs, or by the use of hemlock, as mentioned below for use in Chilkat blankets. Yellow dye, made from tree moss, is also employed, as well as red from an alderwood vessel in which urine has been allowed to stand. A purple is produced by the use of huckleberries. The designs are nearly all geometrical, of the

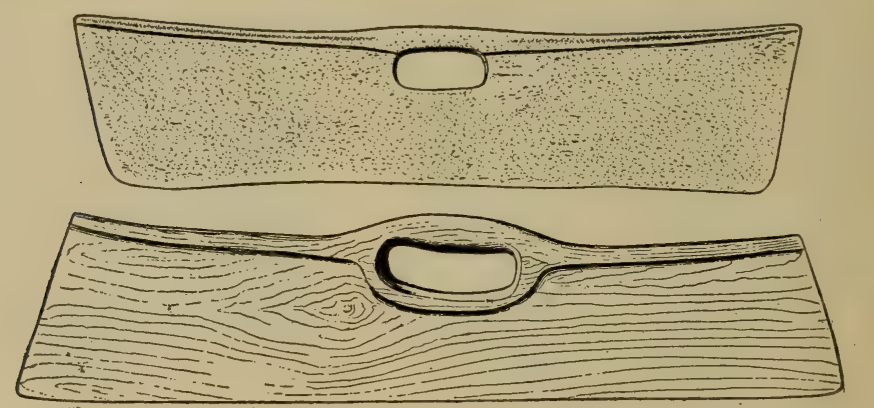

Implements for Shredding Cedar Bark. Upper One of Bone of Whale, Lower, of Wood. Kwakiutl.

sort which seem naturally to develop in textiles made with small stitches. Esthetically, they are among the most pleasing of North American baskets. The technical execution is excellent, the colors harmonize, and spacing is nicely arranged. Formerly these baskets were made for use in the household; for cooking, holding water, and storing food. They vary in size and form according to these requirements.

Cedar Bark Blankets. The Kwakiutl weave blankets and capes of the bark of the yellow cedar. The inner bark is taken from the tree in July and soaked for ten 
days by weighting it down in still, shallow, salt water. It is then beaten across the grain by an implement, in shape and appearance like the tapa beaters of Polynesia, made from the bone of a whale. For weaving, a frame is erected consisting of two stakes set up vertically at the required distance from each other to the top of which a horizontal bar, provided with a groove on its lower edge, is tied. A strip of cedar bark is then fastened to the two stakes and attached just under the horizontal bar. The warp of soft yellow cedar bark is draped over this line which is then pressed into the groove in the horizontal bar and bound tightly in place. The warp fibres are separated into small bundles each of which

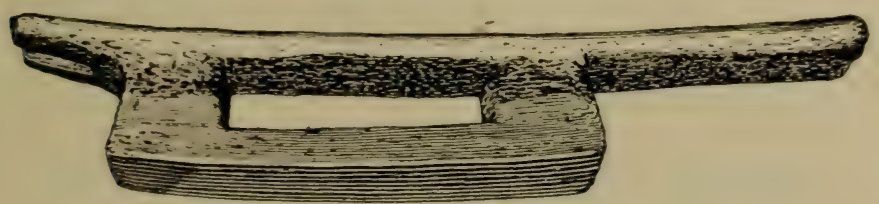

Beater for Cedar Bark. Kwakiutl.

becomes a warp strand. The woof consist of two strands of yarn which are twined across horizontally. The blankets and capes are given the desired shapes by having the tops of the posts incline toward each other, and, by making the warp strands in the middle longer than at the two edges. Yarn of mountain goat wool is used to give a border to these fabrics which in earlier days were also bound with strips of sea-otter fur.

Chilkat Blankets. The Chilkat of the north carried the weaving of the wool of the mountain goat to a very high development. These goats, being wild animals, not domestic ones, are killed, three being required to give sufficient wool for one blanket. The skins are soaked until the wool and hair loosen and can be easily 
pulled off. The hair is discarded and the wool spun between the palm of the hand and the thigh. Twostrand yarn is made for the woof. The warp is prepared by enclosing a two-strand twine of yellow or red cedar bark in a coating of goat wool. Three colors are employed in dyeing yarn for the woof. Black is produced with hemlock bark, and yellow with the tree moss, Evernia vulpina. Decoctions are made of these in urine and the wool boiled in them for some hours and

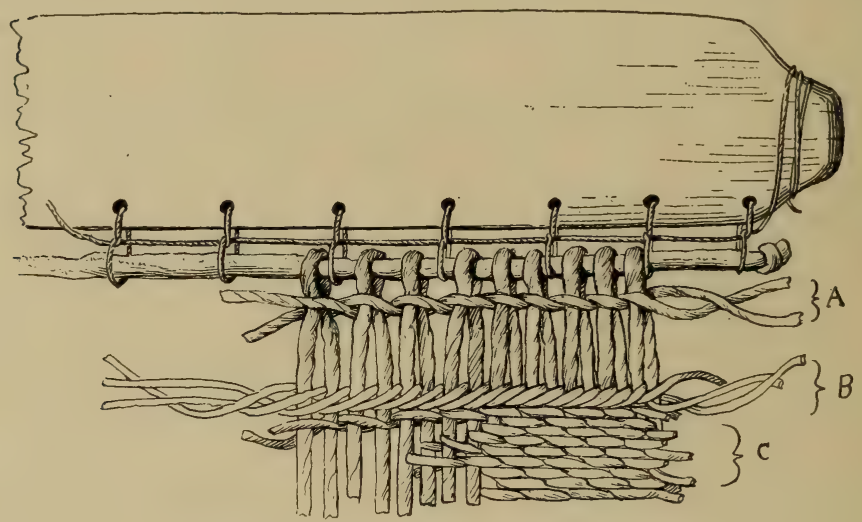

Detail of Suspending a Chilkat Blanket.

allowed to steep much longer. A green blue is produced by allowing copper to corrode in urine and boiling wool in the resulting liquid.

The loom is similar to that used for weaving cedar bark blankets described above. The posts, however, are placed in heavy wooden blocks instead of in the ground. The warp strands are cut in several lengths and then sorted and arranged to give the finished blanket the desired drape and curve at the bottom. The long warp strands of a newly commenced blanket are gathered in bundles and put into bags to confine 
them out of the way and also to keep them clean. Simple two-strand weaving is first employed and then three-strand weaving. In the body of the blanket twostrand weaving is so employed as to produce a diagonal effect. This is accomplished by including two warp strands between each twist and the crossing of the woof strands, and the next time pairing the warp strands differently. The woof strand, which has color, does not go entirely across the web but only so far as is necessary

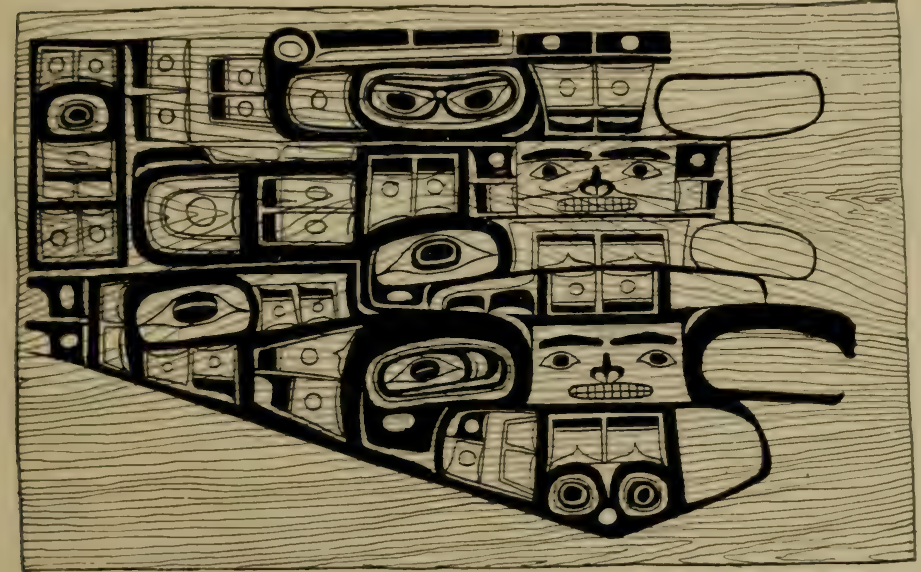

Pattern Board from which Women Weave Chilkat Blankets.

to produce the desired pattern. These designs are the usual conventionalized and semi-religious ones of the region. Since the women are not supposed to be familiar with them they are drawn on a board by some man. The blankets being nearly always bilaterally symmetrical, it is considered sufficient to make the drawings of the pattern include the middle and one side of the board. While these blankets are manufactured only by the Tlingit, at least at the present time, they 
are possessed as objects of wealth by all the coast tribes and are worn on ceremonial occasions.

Salish Blankets. The Salish peoples of the south, particularly on the lower Fraser River, made blankets of a type quite different from those of the Tlingit. In addition to the wool of the mountain goat they had a supply derived from white woolly dogs bred for the purpose. The wool was taken from the dried skins of the animals into which diatomaceous earth was rubbed to absorb the grease and make the fibres adhere more
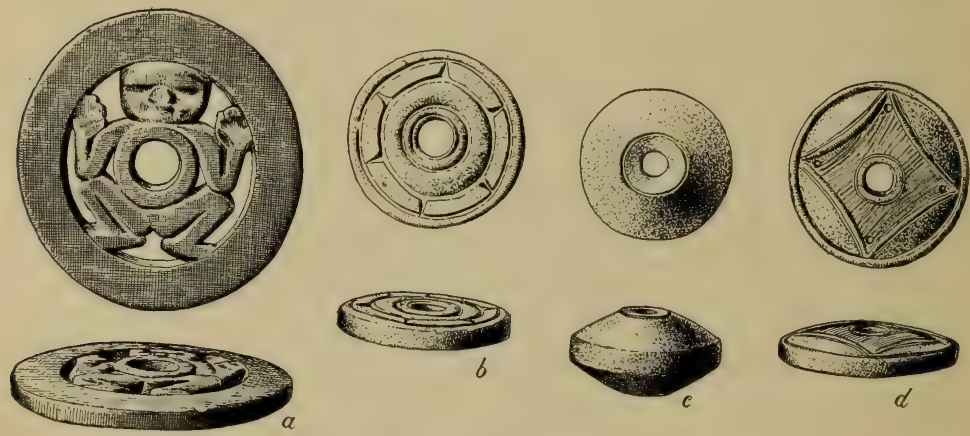

Spindle Whorls.

readily in the spinning which was done between the palm of the hand and the thigh. The spun threads were twisted into two-strand yarn by the aid of a spindle having a large decorated whirl of maplewood. To secure the desired tension, the threads were drawn over a beam or other handy object. With the wool feathers were also combined in spinning. The loom consisted of two up-rights into which two horizontal rollers were fitted. By the use of up-rights of varying heights, any size of web desired could be made. The rollers were wedged apart to give the needed tension to the warp. 
The warp threads were not run spirally around the two rollers but were passed around a tightly drawn cord or a stick and then looped back so that when the web was finished and the cord or stick withdrawn, the fabric would separate into a single piece without cutting. The woman when wearing sat before the loom with a ball of woof which she passed between the warp strand compacting the fabric with the aid of a comb. As the work progressed she drew the warp around the rollers after loosening the wedges which held them in place. The weaving was usually done by grouping the warp strands in pairs producing a diagonal appearance. Occasionally ornamentation was attempted by the use of color, black or brown, introduced as stripes into the warp. The diagonal treatment then produced narrow bands broken with alternate white and colored lines having an upward and downward slope.

\section{Food Getting.}

Whaling. The food of the people of the Northwest Coast is chiefly drawn from the sea. Again distinction may be made between the various portions of the area; the Nootka, of the southern section, having one outstanding achievement in this regard. They and their Quileute neighbors to the south pursue and kill whales, while the northern tribes are content with those which become stranded or are thrown up on the beach dead. It is usually the California gray whale which is taken by the Nootka. The chief harpooner is a man of distinction. who inherits the position, and must submit to many restrictions regarding his food and social behavior. In particular, at the proper season he withdraws to a certain "house" consisting of posts and poles without being enclosed or covered with planks. In this are many wooden figures of men and the skulls of his predecessors. 
Here he keeps his vigils and engages in prayer for success. The equipment for whaling consists of canoes capable of accommodating eight men, and of being taken well outside the sheltered inlets. The harpoons have a head, with a broad triangular blade of metal or shell, barbs made of pieces of antler, lines of thirty fathoms made of twisted whale sinew, floats of seal skin attached to this line, and a shaft of yew wood ten feet long, tapering from the middle toward each end. The outer end of this shaft is inserted in the harpoon head from which it is withdrawn as soon as the whale is struck.

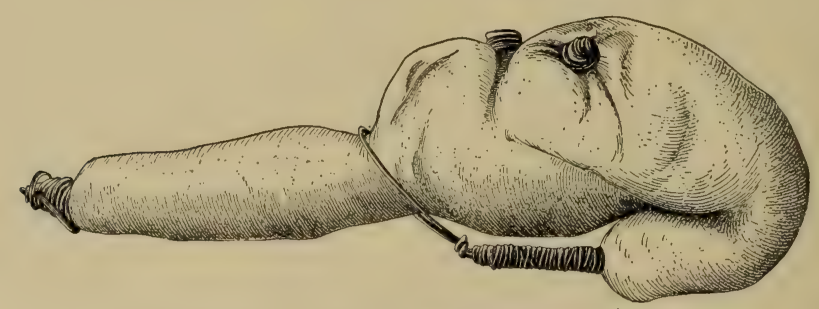

Float Made of Seal's Bladder. Kwakiutl.

The leader strikes at the head of the whale, and, as soon as he has done so, the crews of the other canoes are permitted to place as many harpoons as they can in the body. The movements of the whale are impeded by the many attached seal-skin floats, and he is readily dispatched with lances. The floats, sometimes forty to fifty in number, prevent the sinking of the dead whale which is towed to a beach at or near the village by means of ropes of twisted cedar branches and spruce roots. The whale chief, who throws the first harpoon, is entitled to a piece of blubber from the back between the head and the dorsal fin. This is decorated with feathers and supported by two stakes and a cross-piece until it is convenient to have a feast. The remainder of the whale 


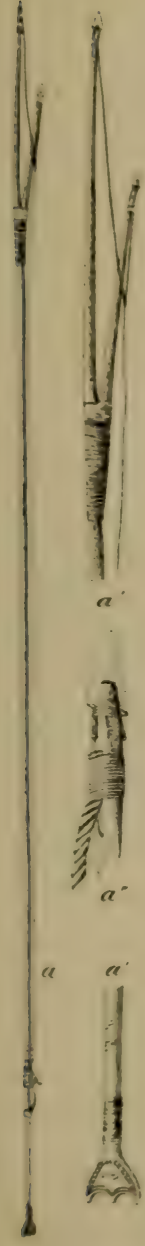

Harpoon for Salmon:

$\mathrm{a}^{\prime \prime}$ Shows

Detached

Head.

Kwakiutl.

is cut up and distributed, the blubber being issued in pieces about two feet square. Practically the entire animal is consumed or used in some way. The black skin is eaten, the sinews are used for ropes, and the digestive organs employed as containers for oil. The Nootka, as well as the other tribes who do not pursue whales, gladly make use of any animal which becomes stranded, or is found alive or dead on the shore. The Nootka take sea-lions in some such manner as described above for whaling. The man who harpoons them inherits the duty and holds a position of honor second to the chief whaler.

Hunting Porpoises. Porpoises are taken with a harpoon. The Kwakiutl use a special canoe which at first is made and is afterward kept as smooth as possible, never being dragged on the ground or allowed to grate on the shore. It is greased with tallow and scented with spruce boughs. The crew consists of a steersman and a harpooner who directs the operations, communicating with the steersman by means of signs. Great care is taken that no noise is made in paddling. The harpoon is two-pronged, with detachable barbed heads, fastened to a long line. A float is attached to the line, midway of the harpoon shaft. When a porpoise has been approached within a striking distance, a harpoon is thrown, and the canoe backed to avoid the wounded animal, which dives and comes up again near the same spot. The canoe is then brought close to the animal which is given a thrust through the body with a har- 
poon handle. Usually several canoe crews engaged in such a hunt encircle the victim.

Sealing. Seals are hunted in much the same manner as are porpoises. Care must be taken after harpooning them that the seal be not permitted to swim through kelp or seaweed and tangle the line which will be broken or pulled loose, if he is permitted to do so. The hunters keep driving him under water with the harpoon pole which is now detached from

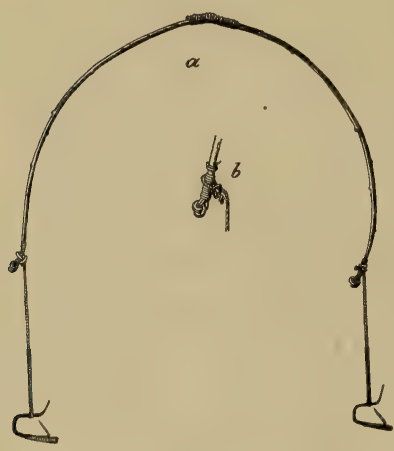

Halibut Hooks Set in Pairs. Kwakiutl. the points until the seal is nearly or quite drowned. A blow with a club finishes him if that is necessary. The seal hunters know where the seals customarily sleep. When they take to the water, the harpooner thrusts into the phosphorescence under the water and secures the seal before he has time to get far away. Seal meat is highly prized and much used in the feasts of the aristocracy.

Many varieties of fish are furnished by the ocean and its inlets. Chief among these are the halibut, cod, salmon, and olachen. The particular water conditions seem to determine which of these fish in each locality holds the first place as food.

Halibut Fishing. In certain regions the halibut is of special importance. There are excellent banks off the coast of Washington, in Queen Charlotte Sound, and in Dixon's Entrance, north of the Queen Charlotte Islands. The Makah and the Haida, therefore, make great use of halibut. The method of taking these fish is everywhere the same. Large hooks are used, those of the Nootka 
and Kwakiutl being made by bending a fir or hemlock stick as described above. Further north a V-shaped hook is made, and ornamented by carving. A barb of sharp bone or antler is provided on which a piece of squid is placed as bait. The hook is attached to a line made of kelp stem, about one-quarter of an inch in diameter, and very strong when wet. The other end of the line is attached to a float; and a sinker placed below rests on the bottom, steadying the hook and holding it in a vertical position. The Kwakiutl are accustomed to set these hooks in pairs so that only one sinker and one float are required for the two hooks. When the huge fish with its upright mouth takes the bait, the outer curves or prongs of the hook pass outside of its mouth and serve as a lever to drive the barb deep into its flesh. In the accounts of the earlier voyages, great praise is given to this device which the white seamen themselves adopted with profit.

The fish are cleaned by the women on the shore, who cut off the heads and tails for separate treatment. The skin is also taken off and dried separately from the flesh which is thinly sliced for drying. The heads and tails are cooked by boiling and steaming, and the dried skin is toasted over the fire, while the dried white flesh is dipped in oil and eaten without cooking.

Cod Fishing. Cod and kelp fish are also taken with a line anchored in a horizontal position near the bottom, to which are attached a number of baited hooks. Siome of the Kwakiutl fasten the sinkers in such a way that they become detached before the line is pulled up, saving the exertion of drawing them to the surface.

Salmon. Salmon for many of the tribes furnish a large part of the food supply. Formerly they were taken by a number of methods. Trolling was practiced with a straight hook provided with a sharp barb placed at an 


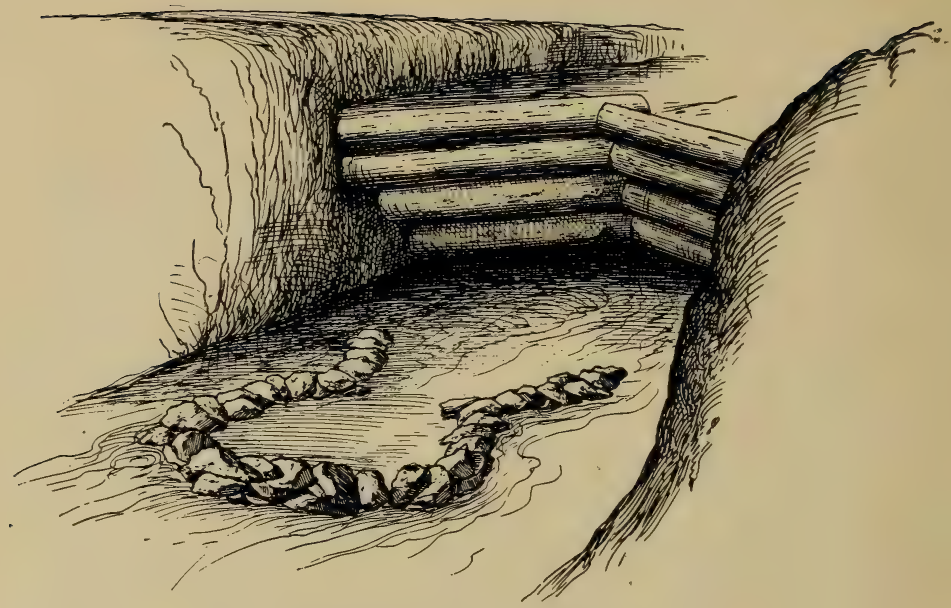

Dam and Fish Trap. Kwakiutl.

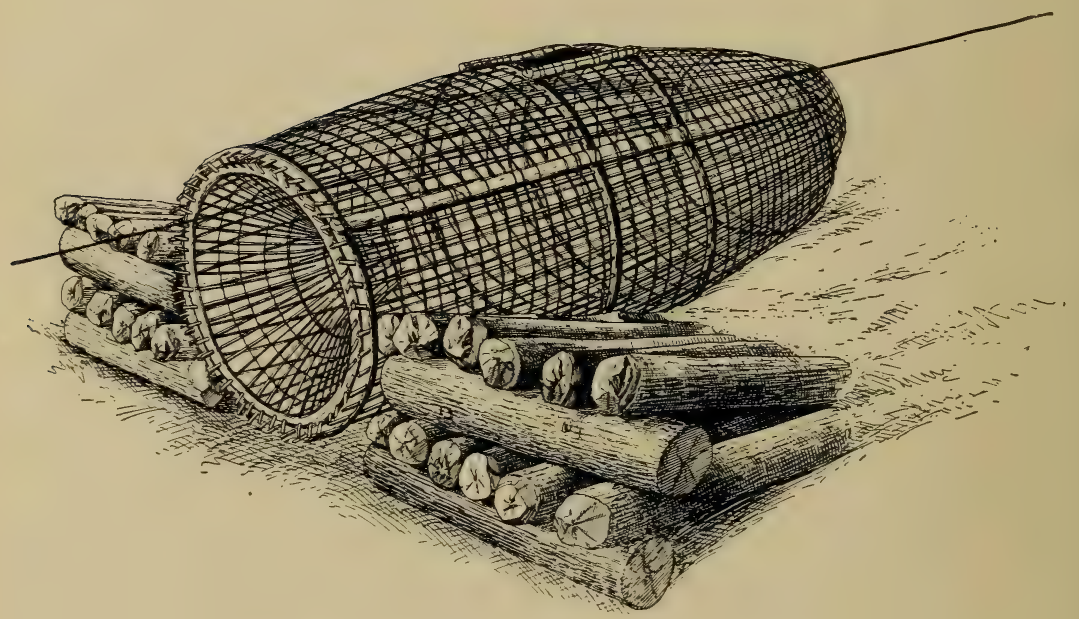

Dam and Fish Basket, for Salmon. Kwakiutl. 
acute angle. The baited hook trailed on the end of a line having the other end attached to the hand with which the fisherman paddled. The motion imparted in this manner to the hook simulated the movement of a live fish and attracted the salmon.

Where the condition of the water permitted,"a twopronged spear similar to the one employed in harpoon-
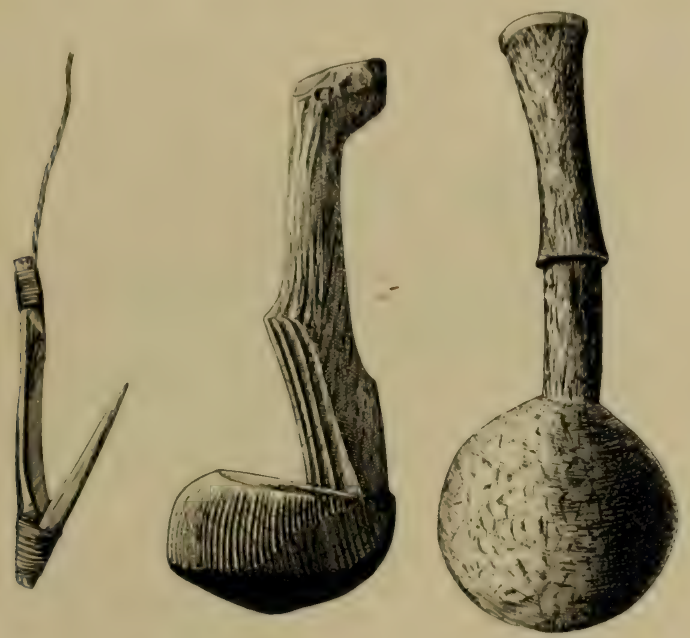

Trolling Hook for Salmon. Clubs for Killing Halibut. Kwakiutl.

ing porpoises was employed. Long nets were formerly used by the Salish, who lived near Victoria. Nettles furnished the fibres which were twisted into twine, and tied to form the nets. When the salmon arrived, the chief who owned a fishing place invited his relatives to join him for the season. The men were divided into two groups, who during the season lived with their families on either side of the salmon drying racks. The chief's quarters were at the end of these racks opposite the 
water. From these two groups were chosen the crews for the canoes employed in fishing. Two anchors of large stones were placed at a distance from each other equal to the length of the net. Buoys were attached to the anchors, and the canoes were moored to them during the fishing. The net was stretched between the canoes

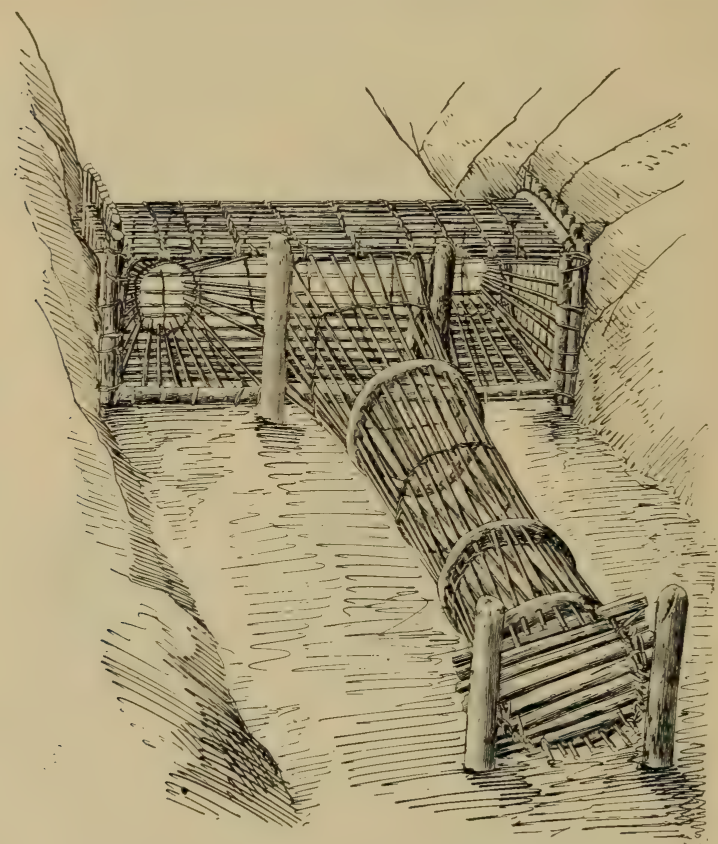

Salmon Trap for Narrow Streams. Kwakiutl.

until it was full of fish, when one of the canoes was brought toward the other, the net being pulled in as the canoes approached. Nets were used by the other tribes also, especially in the rivers, where they were stretched between two canoes by means of which they were drawn down with the current of the river or against the flow 
of the tide. These were either gill nets, in which the fish were caught when they tried to pass through; or they were provided with trailing pockets, into which the salmon passed.

Weirs. The most common method of taking the salmon requires some sort of weir across or at the sides of a stream, associated with which are fish baskets for collecting the fish; or an advantageous place for spearing them. Because of the variations in the size, depth, and swiftness of the streams, there are many forms of these weirs and traps, adapted to the particular localities

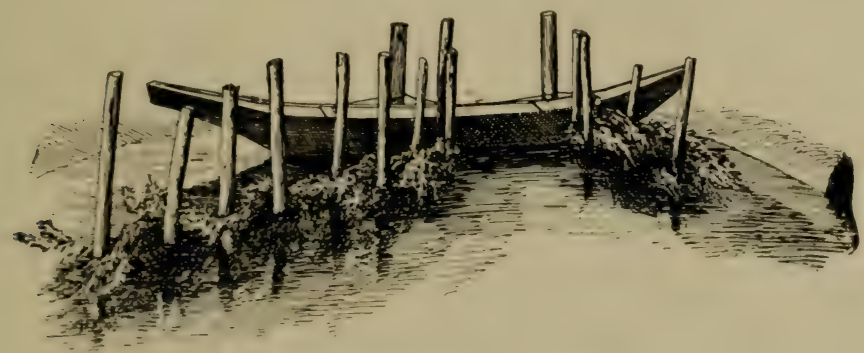

Weir for Olachen Fishing. Kwakiutl.

where they are used. The character of some of these will be readily seen from the illustrations.

Gaff Hook. In shallow rivers, such as the Nimkish in the Kwakiutl territory, and the Chilkat River of the Tlingit, dog salmon are easily secured by means of a hook attached to a long pole. The hook is drawn along the bottom toward the canoe in which the fisherman stands. This is done at night, unless the river is sufficiently roily, as is the case with the Chilkat River, so that the salmon do not see the fisherman. The fish themselves are in such numbers that it does not matter that the fishermen cannot see them. Along the rivers 
are suitable places for fishing from a platform extending from the bank over a pool or eddy. The fisherman uses either a net or a gaff hook on a pole. Such favorable fishing sites are highly prized possessions.

The women receive the salmon at the shore and prepare them for curing. The heads, tails, and fins are removed, and the fish split from the back down each

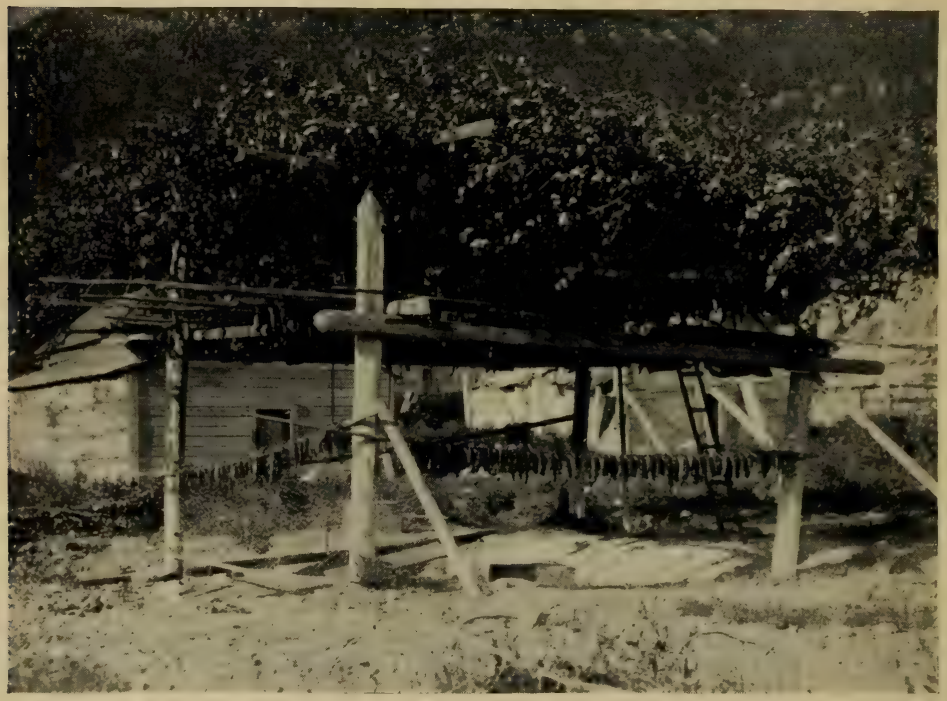

Salmon Drying. Chileat River, Alaska.

side of the backbone to which some of the flesh adheres, making three parts for drying. The heads and tails are boiled or steamed, and eaten fresh, while the sliced bodies and the roe are hung on poles to dry in the smoke of the fires.

Olachen. There is still another fish of great importance in the life of the northwestern people, the olachen, Thaleichthys pacificus. These fish are rather small, nine 
to twelve inches long, but they arrive at the mouths of certain rivers in great multitudes. The Nass River, in the Tsimshian country, is the most noted fishery for olachen. The first arrivals are in the middle of March, and they continue to come for about six weeks. As the fish come up to the mouth of the river, they are pursued by seals, sea-lions, and whales; and while the fish are in the river, great flocks of seagulls appear every day and feed upon them until night.

The fish are taken in nets, which early in the season must be put through holes cut in the ice. Piles are driven deep into the stream bed by means of stone pile drivers. Sliding on these posts are rings to which the net is attached. The lower ones are pushed to the bottom of the river with a pole when the net is open for use. The nets are long, bag-shaped, with a wide mouth stretched open upstream. The combined outrushing tide and current of the river keeps the small end downstream while it fills with fish which are removed through an opening in it. During the period when the ice is running out of the river fishing is difficult, for the nets are likely to be carried away; and canoe navigation in the running ice is hazardous. After the ice is gone, the nets must be newly opened at every tide.

The oil from the fish used to be tried out by putting hot rocks in large wooden vessels, or canoes, keeping the water boiling until the oil from the fish gathered on the top, where it was recovered after it cooled. The fish after being boiled were pressed, to force out the remaining oil. Formerly the women did this by squeezing the still hot fish against their naked breasts. The accumulations resulting from this process were not allowed to be wiped off until the season was over. Nowadays, the rendering is done in home-made furnaces of sheet metal under which fires can be maintained; and presses with 


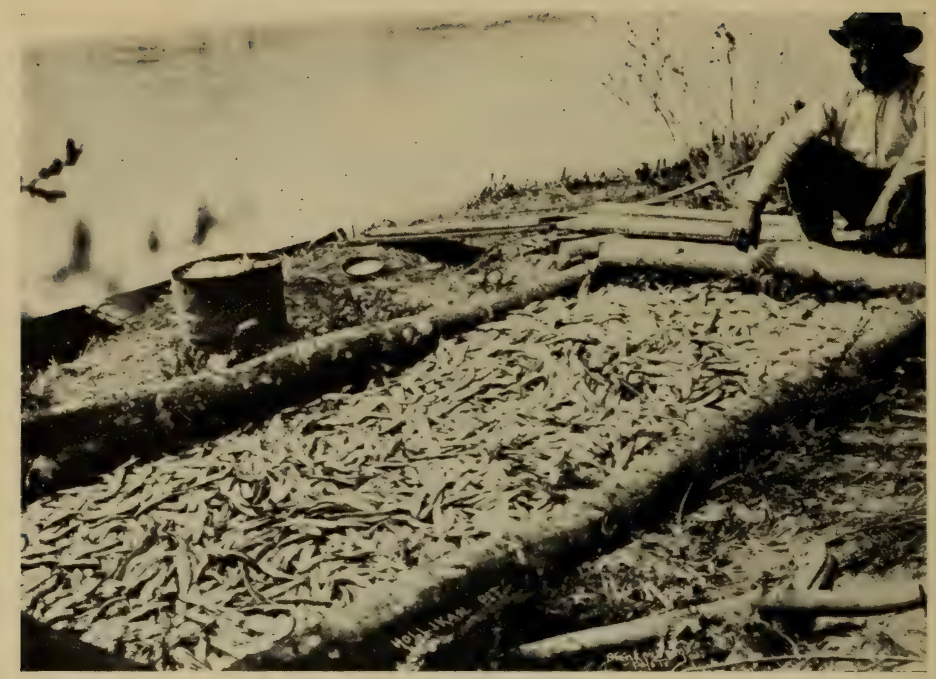

Olachen, or "Candlefish" in Storage.

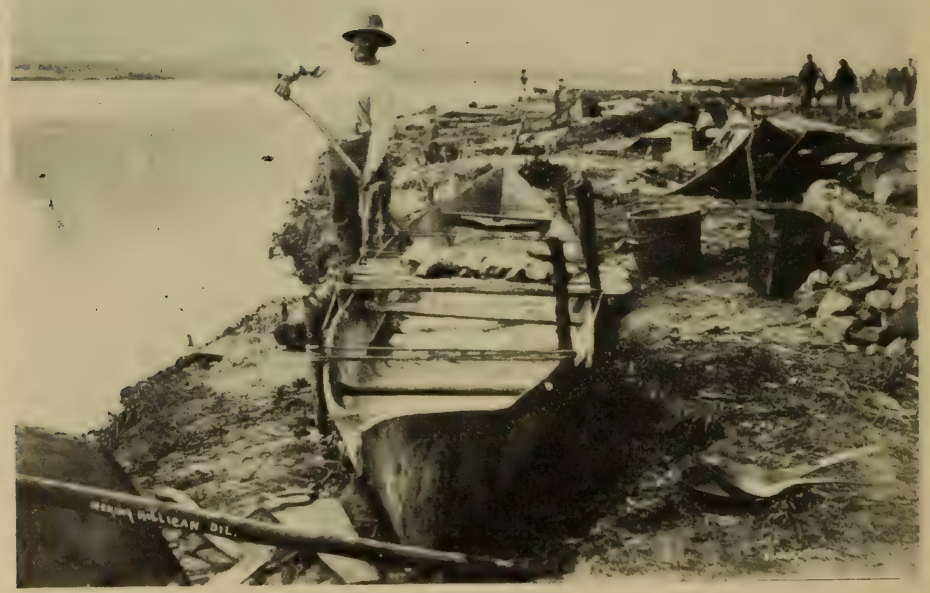

Rendering Olachen Oil in a Canoe by Means of Hot Stones. 
levers are provided for extracting the oil from the cooked fish. It is the custom to allow the fish to decay somewhat before submitting them to this process since the oil
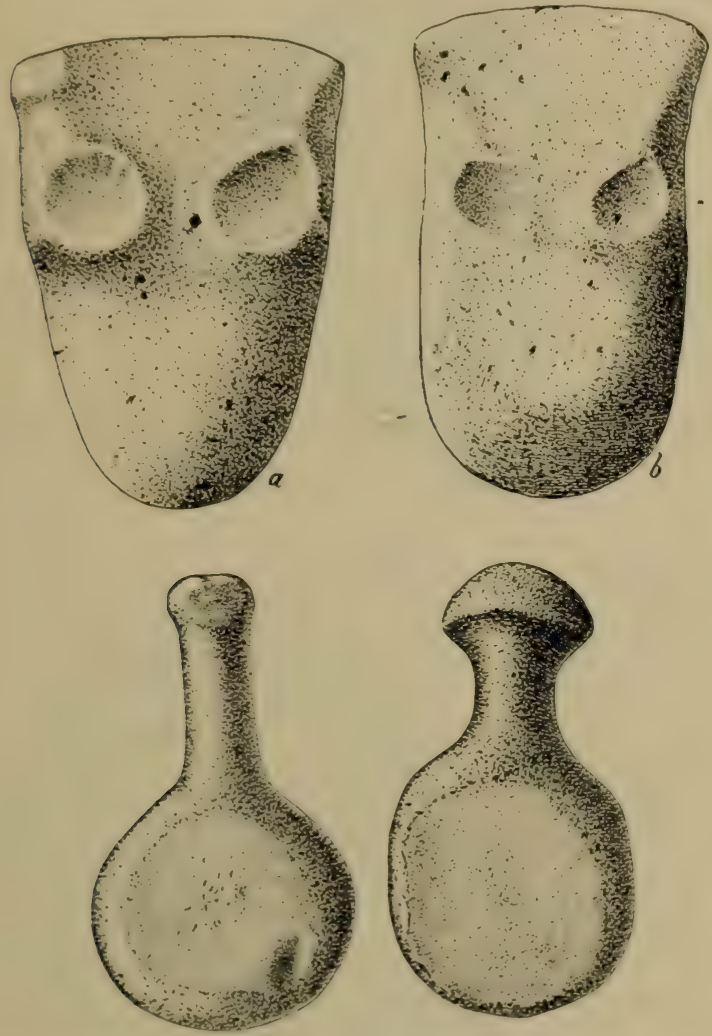

Pile Drivers: a and b, Bella Coola; Lower Pair, Quinault.

is more easily separated, and the Indians are not prejudiced against the odor or taste of slightly putrid fish oil.

The olachen oil is highly prized; dried salmon, halibut, and other kinds of food being dipped into it. 


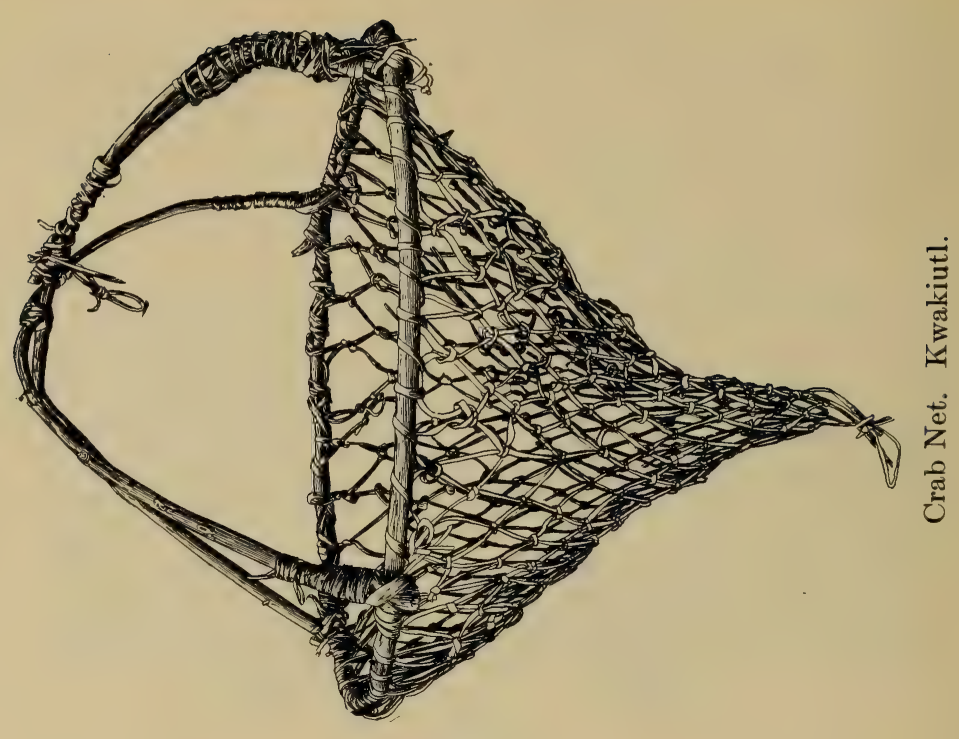

N

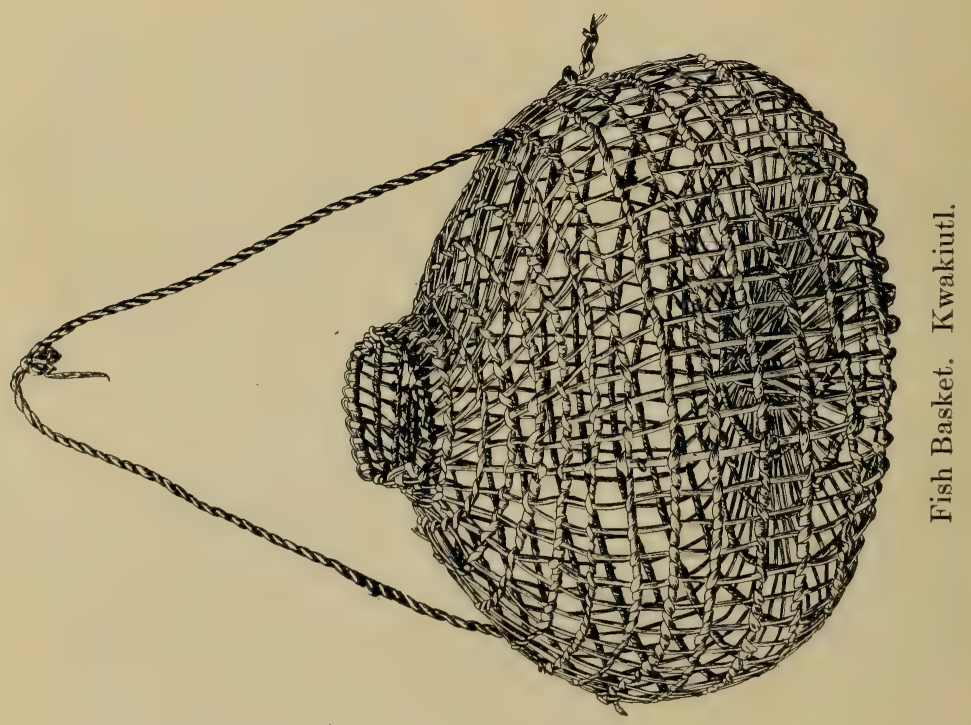


It supplied the necessary hydrocarbons, otherwise lacking, because starches are scarce in their diet. Very extensive trade in olachen oil was formerly carried on. Indians from a distance came to the favorable fishing places, and bought temporary rights to fish and render the oil. Long trails, known as grease trails, led into the interior, where trade was carried on with the Athaspascan-speaking tribes. The oil was also traded by canoes among the Northwest Coast people to the south and north. It does not deteriorate with time and may, therefore, be stored for a year or two. This is desirable for the great runs of olachen do not occur every year.

Herring Rake. Kwakiutl.

Herring. The spawn of herring is collected for food, usually by anchoring quantities of cedar or hemlock brush in the spawning places. When the brush is withdrawn it is covered with a mass of eggs. The Tlingit and Tsimshian gather the seaweed on which the herring have spawned. The herring themselves are secured with a rake which consists of a stick with a row of nails which have taken the place of the sharp pieces of bone, formerly used. The fisherman sits in the stern of the canoe, while his wife paddles in the bow driving the canoe astern. The rake is swung like a paddle, the fish being impaled on the points of the rake, and shaken off into the canoe. Olachen are also taken in this manner. In early spring, herring driven by their enemies. come to the coast in numbers so great that they cannot find room in the shallow water, and force each other either ashore, or into the air above the water's surface. 
Shellfish. Beside these major products of the sea certain minor ones are of considerable importance, such as shellfish. The Haida class these together as low tide foods, and taboo them under certain circumstances. There are two important species of clams. The more common one is of ordinary size and fairly abundant. It is the woman's duty to dig them, which in former times she accomplished with a digging stick and a large shell. In transporting them she protects herself from the salt water, by placing a mat on her back under the carrying basket. For immediate use these clams are roasted above a fire, or steam-cooked in a box. When larger quantities are being made ready for future use, the

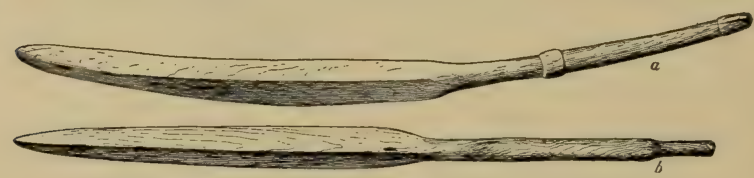

Digging Sticks. Kwakiutl.

cooking is done by steaming under a covering of seaweeds and mats. The clams are then removed from the shells, and strung on sticks, or a strand of bark. These are exposed for some time to the heat of a fire, and then placed in smoke until they are thoroughly cured.

The very much larger horse clam is also used for food. The shells of these are 8 or 10 inches in length. It is with some difficulty that they are secured, as the clams are capable of withdrawing from the surface with considerable speed. These are cooked by steaming; and are strung on three sticks, because of their size. They are then exposed to the action of fire and smoke as are the smaller clams. Cockles, mussels, and many, other forms of sea life contribute to the food supply which 'is's so 
varied that famine was practically unknown among the tribes living directly on the coast.

Vegetable Food. The vegetable diet of the Indians on the Northwest Coast was quite varied, but not particularly abundant. They did not have the aid of agriculture as did the Indians east of the Rocky Mountains in the United States, nor did they have acorns in abundance as was the case in California. From the sea they took eelgrass and seaweed. They made use of fern and bracken roots, and the roots of clover. They had a fair variety of wild fruits including elderberries, huckleberries, salmon berries, currants, gooseberries, rose hips, salal berries, and crab-apples. The roots were cooked

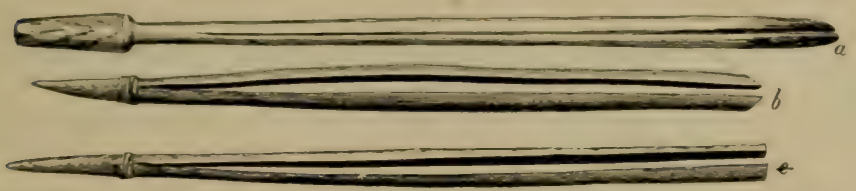

Tongs: Lower Two are Sharpened for Thrusting into the Ground When Used for Roasting. Kwakiutl.

by steaming in underground ovens or were roasted on the coals and eaten with oil. The seaweed was allowed to decay a little before being dried and stored for winter use. The dried weed was chopped up with an adze and chewed before being boiled and served in oil. The berries were usually cooked, dried, and put away in cakes. These were soaked in water, broken up, and kneaded until soft, covered with oil, and eaten with a spoon. Huckleberries were mixed while boiling with salmon spawn and packed away in wooden boxes sealed with olachen fat. The wild crab-apples served with oil were a favorite dish. Starches, except in the south, were poorly represented, found chiefly in the form of 

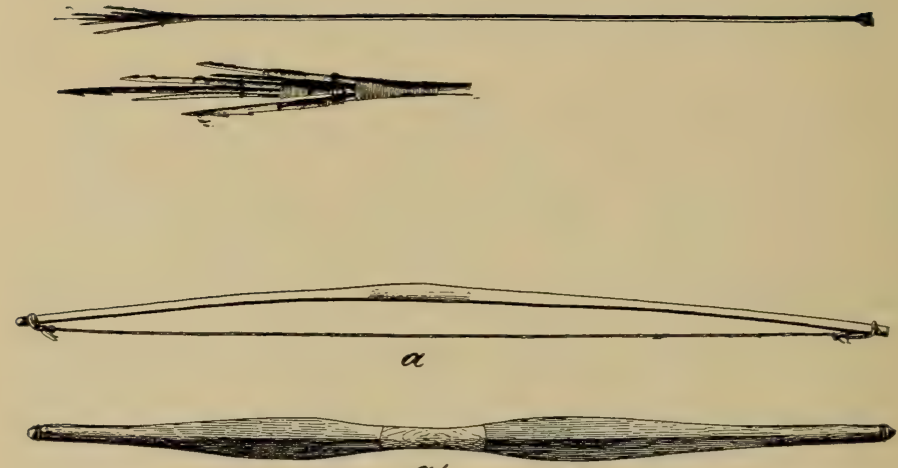
a
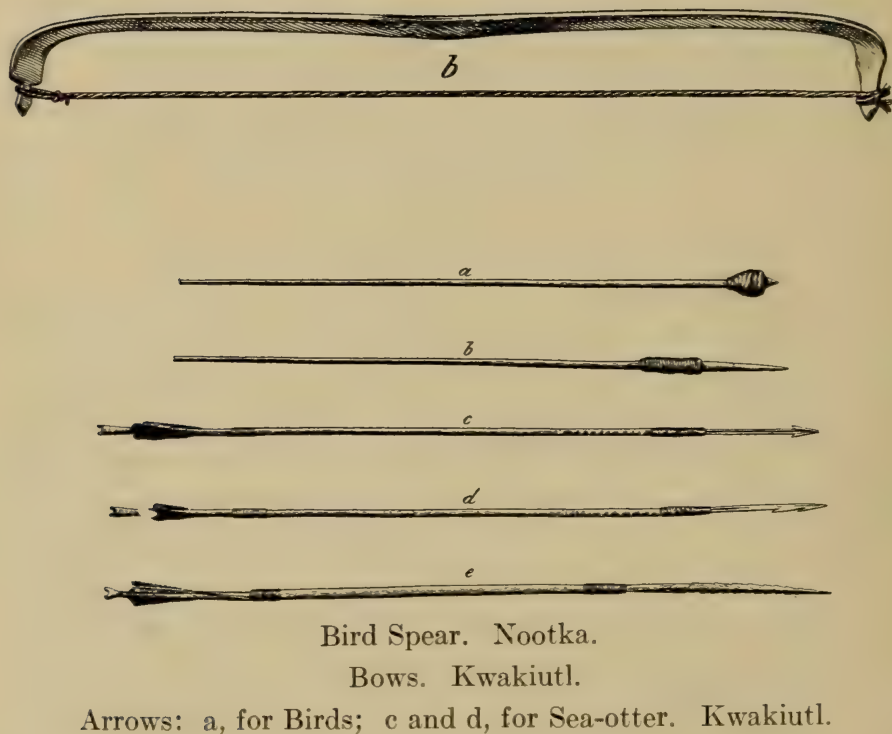
lily bulbs. In southern British Columbia and in Washington the camas is plentiful. It is cooked in quantities in underground ovens and provides excellent and palat able food. Wild seeds and grains so much used in California and the Great Basin were not used on the Northwest Coast. In the spring quantities of the inner bark, cambrium layer, of the hemlock are removed and stored for winter use. To secure a supply with little labor the trees are climbed by the northern tribes.

The clover roots mentioned above are secured from "clover gardens" situated on low ground where a wild clover grows abundantly. These gardens are family property which cannot be sold or given away, but descend in the family by inheritance. The clover roots are dug in the fall after the leaves of the trees fall. Pebbles are removed and roots unsuitable for food are sometimes replanted, but otherwise the growth is unassisted by the owner.

Raising Tobacco. The people of this region were referred to above as non-agricultural. As was the case in California and certain sections of the Great Plains, tobacco was cultivated. The tobacco (Nicotiana attenuata) was grown in small gardens near the villages. It seems not to have been smoked, however, in preEuropean times, but chewed with lime. The dried leaves and stems were reduced to a powder in small stone mortars. Small portions of the powder were placed in the mouth to which was added with a stick quick-lime obtained by burning clam shells. It is quite remarkable that the habit of smoking so nearly universal in aboriginal America should not have obtained on the Northwest Coast.

The culture of potatoes was introduced in the period of the early voyages by explorers and traders, and quickly spread wherever conditions were favorable. 

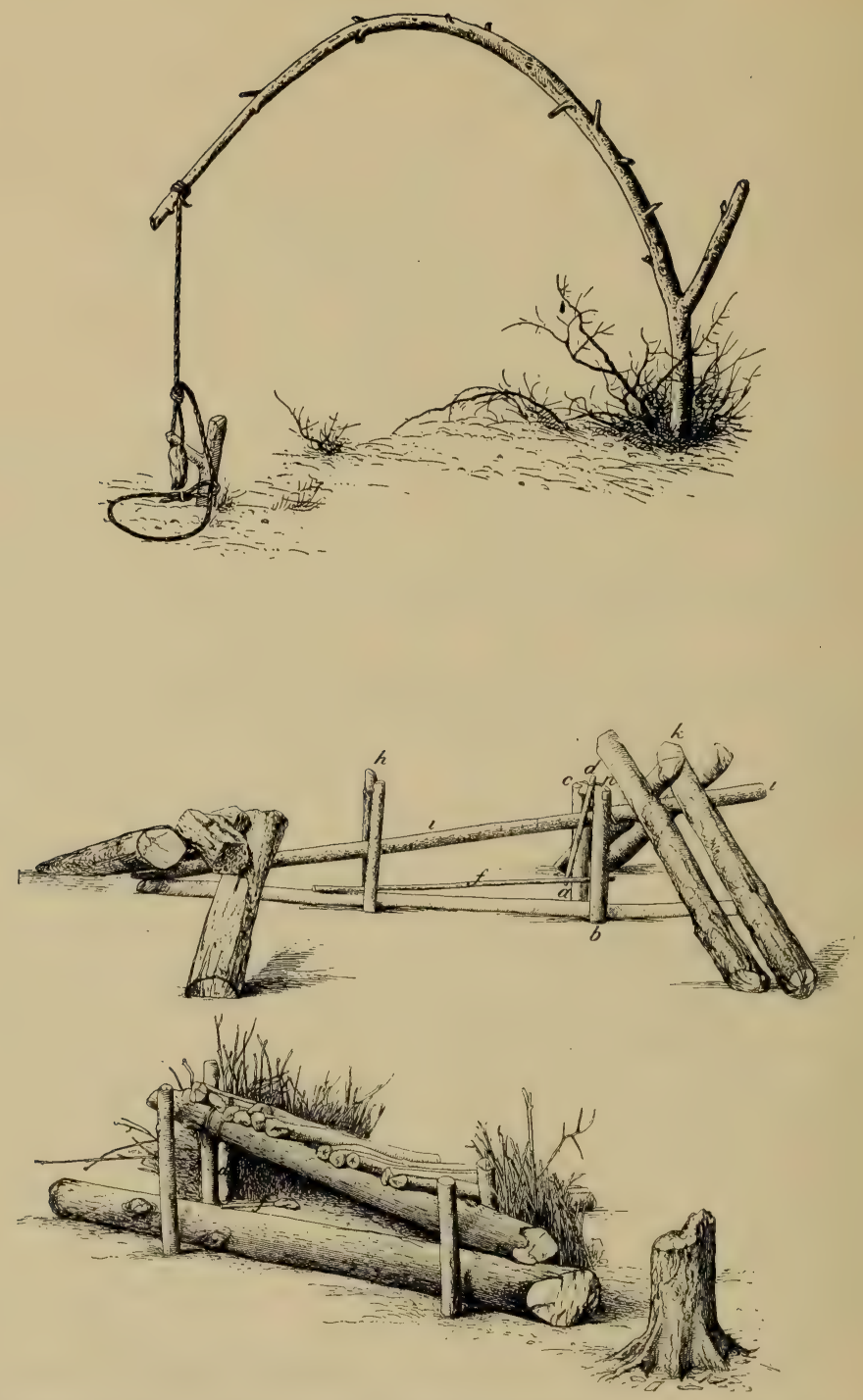

Spring Trap: Used for Bear, Deer, and Smaller Animals. Kwakiutl. Deadfalls. Kwakiutl. 
Land Animals. One of the most surprising facts in regard to the food supply of the Northwest Coast is the small share occupied by the hunting of land animals. Deer are taken by snares or shot with bow and arrow, but mainly for their skins. In the south among the Kwakiutl venison is never eaten. The Nootka sometimes use the flesh of the deer, but if they do so they are not allowed to eat salmon until some months have elapsed. Bears killed in deadfalls are given a ceremonial welcome and feast. The eating of their flesh is attended by similar taboo against salmon.

Mountain goats were much hunted by the tribes of the mainland. They did not occur on the islands. Nooses were set in the trails where there was a sheer wall above and below so that the trail must be used. The goats were also run with dogs and when cornered or brought to bay were taken by dropping a noose over their heads. The tales mention shooting them with arrows, but for the sake of the wool the shedding of blood was avoided. The wool was much prized for the making of blankets. The flesh was eaten fresh or cured with smoke and sun, and stored away in large quantities for future use. There seem to have been no taboos similar to those which prevented the eating of deer flesh by the Kwakiutl.

\section{Dress and Decoration.}

Barefooted. One of the striking features of the Northwest Coast, distinguishing it from the remainder of North America, is the almost total lack of footwear. In Mexico, Arizona, and southern California, sandals are used, protecting the feet, not against the cold, but the hard surface of the ground. East of the Rocky Mountains and west of them also, nearly to the coast, moccasins of some sort are worn. Those in the east are made with soft soles, but through the Plains region with 


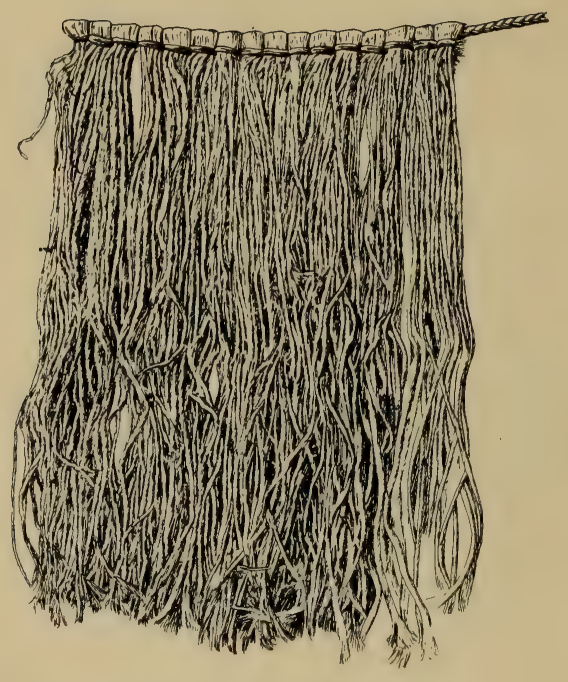

Woman's Apron. Kwakiutl.

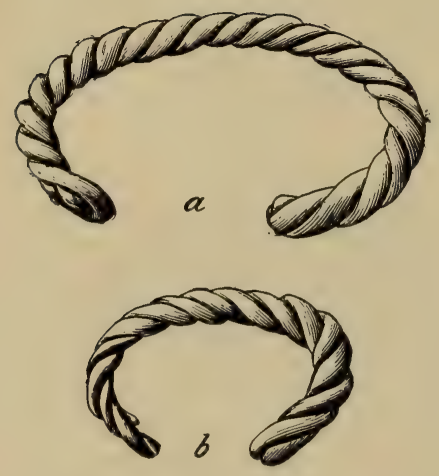

Ornaments: a, Anklet; b, Bracelet.

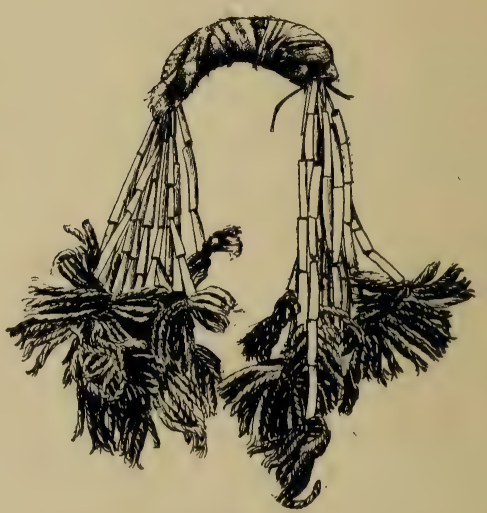

Hair Ornament of Dentalia Shells. Kwakiutl. 
hard soles, better able to withstand the dry, hard trails. The Northwest Coast people, except in the far north and in the interior, go summer and winter with bare legs and feet. They are not accustomed to land travel and, therefore, need less protection for their feet than do the Indians living inland. The cold months are also wet months, and untanned leather soon becomes watersoaked and of doubtful value as foot covering.

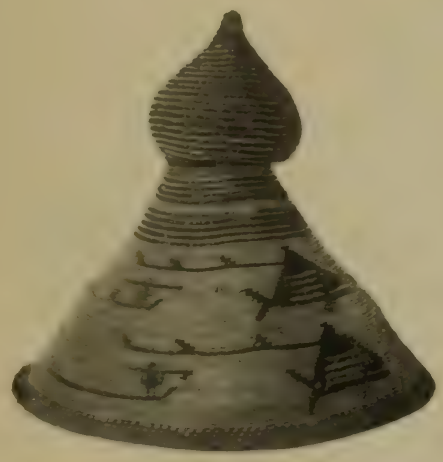

Hat on which Whale Hunting is Depicted. Nootka.

Men's Clothing. Also along the coast the men had no feeling of shame, such as the Plains Indians clearly have, in regard to being uncovered. A Plains man appears anywhere in breechcloth and moccasins, but never without the former. The men of the coast lacked this article of dress, and were accustomed to go about in summer entirely devoid of clothing. For ceremonial occasions and in the cold weather of winter, they wore a robe of skins or woven fibre. This was rectangular and was wrapped around the body under the left arm and over the right shoulder hanging to the knees. When Europeans first visited the coast, many of these robes were made of seaotter skin, the buying of which from the backs of the people inaugurated the fur trade of that coast.

Waterproof mats, cut like a poncho with a hole in the center for the head, were worn by both men and women in wet weather.

The beard was eradicted, except by some of the older men; the hair was worn long, loose or bunched on top of the head. Slaves were compelled to wear their hair 
short. Hats were worn by the men when in their canoes at sea. On dress occasions especially, the body and face were covered with oil over which red ochre, mica, and sparkling sand were applied. On all religious occasions, white down was strewed over the hair. Down was a symbol of peace and goodwill the use of which is often mentioned in the early accounts. The men were very fond of ear and nose pendants, using for the purpose twigs of cedar, feathers, pieces of wood and bone, and, when they could be secured, metal objects of all descriptions.

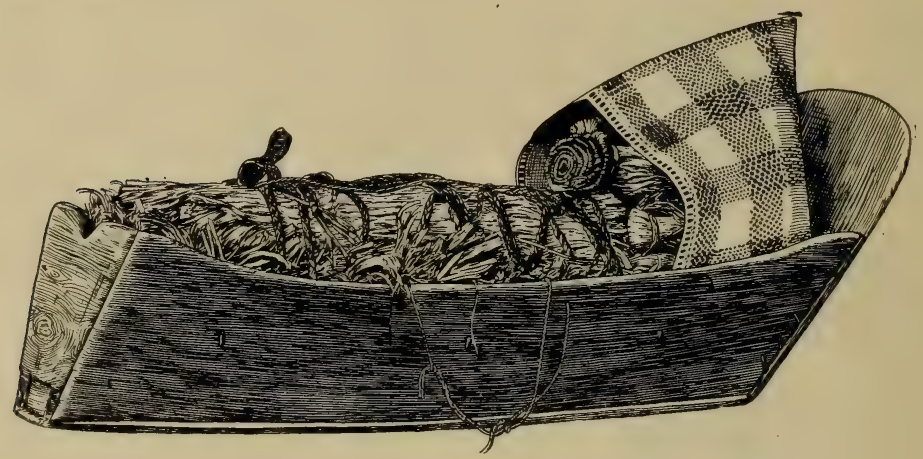

Cradle with Cedar Bark Bedding. Kwakiutl.

Women's Dress. The women had aprons of shredded bark tied around the waist and falling to the knees. Except on rare ceremonial occasions, this garment was not laid aside in public. Ordinarily, the women wore also a garment made of cedar bark which covered her from her shoulders, where it was fastened about her neck, to her ankles. A girdle was worn with this, confining it to her waist. She also wore tight bands about her ankles, and also bracelets, nose and ear rings. In the north the Tsimshian, Haida and Tlingit women had their lower lips slit and a piece of wood inserted. This 


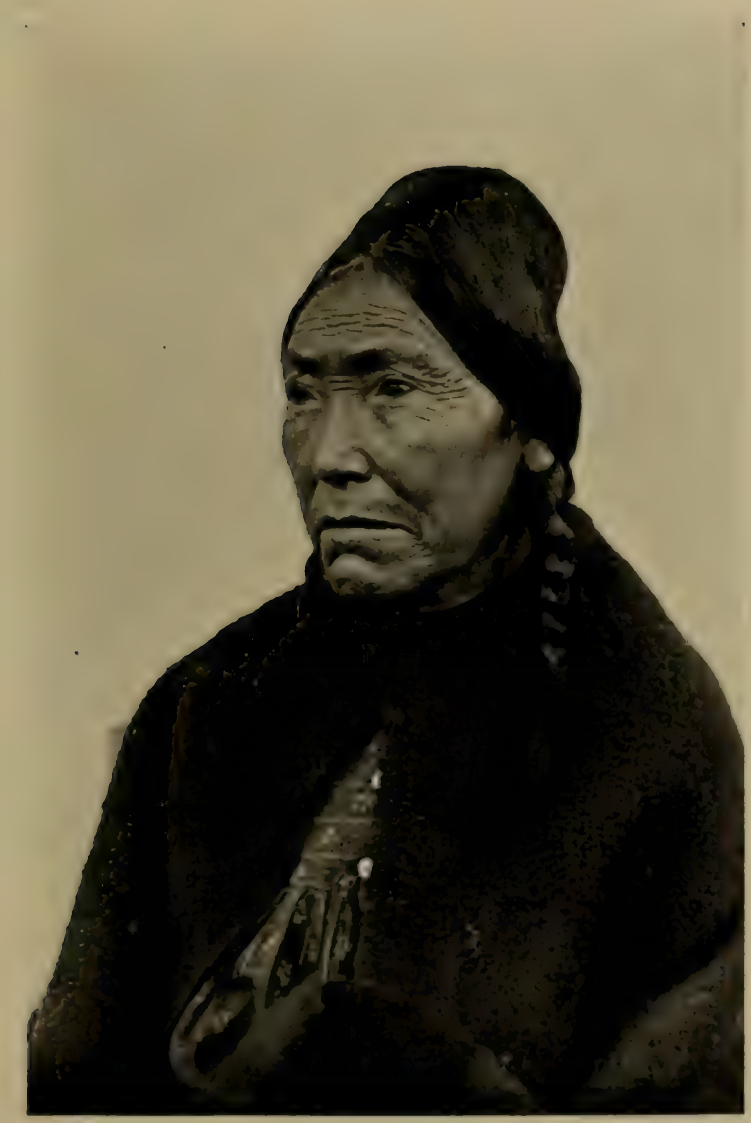

Kwakiutl Woman with Deformed Head. Sugarloaf Type. 
opening was increased in size according to her age and rank. Ultimately the labret of grooved wood might measure three by four inches. This held her lip in a horizontal position as long as she wore it; but when it was out the lip fell down on her chin.

Tattooing. Among the Haida, tattooing was generally practiced on both sexes. This was done, as is usual in America, by introducing carbon in the form of soot under the skin, resulting in a blue color. The tattooing was chiefly applied to the front of the legs and back of the arms, and less frequently to the chest. The designs represented inherited crests and were done in the symmetrical conventional style used in painting.

Deformed Heads. There were two types of head deformation practiced on the Pacific Coast. In Washington and northward among the related Salish of British Columbia, the forehead was flattened so that the head sloped back from the eyes to a summit at the back of the occiput. Since this treatment was not permitted for the slaves, such a head indicated a freeman. Just north of the area where head flattening was practised, another style prevailed among the Kwakiutl. The top of the head was bound around so as to decrease its diameter and elongate it upward and backward, producing the sugarloaf type.
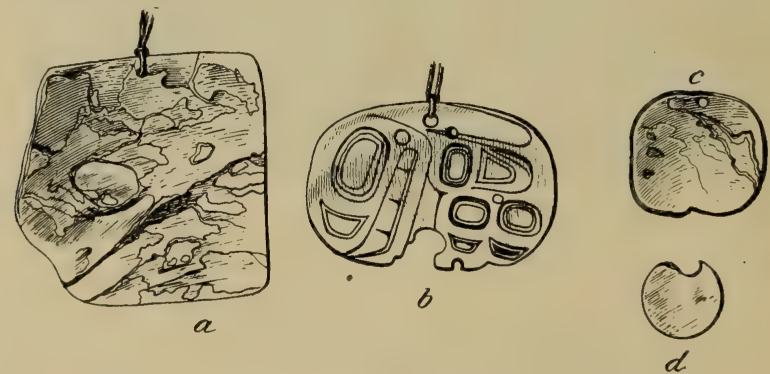

Nose Ornaments of Abalone Shell. Kwakiutl. 


\section{Chapter III.}

\section{SOCIAL AND POLITICAL ORGANIZATION.}

\section{Social Distinctions.}

The Indians of the Northwest Coast are strikingly different from the other natives of North America in three particulars which affect their social life. Briefly these are: the custom of keeping slaves; the high regard in which those are held who, having accumulated wealth, impoverish themselves by distributing it ; and the existence of an aristocracy consisting of those men and their immediate families who have inherited certain property, duties, and powers.

Slacery. Perhaps all the tribes of North America were accustomed to take captives in war. Among the people of the Plains the lot of these captives was generally an easy one. The women and girls were married into the tribe of their captors and their children took their places as equals in the community. The captive boys were usually adopted, and became companions of the sons of the family. In contrast, the tribes on the Pacific Coast kept such captives in slavery, allowing them to mate only with each other, and continuing their descendants in slavery perpetually. Physically, they were not subjected to particular hardships, since they ordinarily lived in the house of the master, and were well fed and clothed. Socially and politically, they had no standing, and were clasised as chattels. There was no one to resent their ill-treatment by their owners, or to avenge their death. Slave trading was not particularly developed, but the giving away of slaves was commonly practised, especially in connection with marriage. In the south, when a man was showing his disregard of property, or was trying to shame his opponent, he killed some of his slaves in the same spirit 
in which he broke up his canoes. The Kwakiutl have definite accounts of the killing of slaves to provide food for the members of the Cannibal Society; and among the Tlingit slaves were killed and buried under the house posts, when a new house was being erected.

Social Rank. It appears that there were certain groups and families who occupied a fixed position of inferiority. Some of these were the poor relations of others who were in better circumstances. In general, they were without inherited possession, such as opportunities for fishing, and for the gathering of vegetable food. They were, therefore, dependent on the more fortunate for opportunities to secure a living; and the acquiring of a surplus was out of the question.

Above these, and below the chiefs and their relatives, were the general mass, who differed, however, among themselves in social standing according to their family connections, and their possession. It was in this middle class that a man might greatly advance himself in social esteem. The criterion on the Pacific Coast was wealth. Among the Plains tribes it was warlike deeds; and the majority of men lived their entire lives in preparation for the execution or in the recital of martial exploits. In much the same spirit, the men of the Pacific Coast devoted themselves to elevating, first themselves, and then their heirs, by the accumulation of wealth.

Feasts. There are two related uses for this accumulated wealth. Practically every social event requires the giving of a feast, necessitating a proper house, and an ample supply of food. Also every such event requires the distribution of property, some of it in payment for services rendered, but much of it being bestowed on the guests of the occasion, according to their rank. The events requiring feasts are the naming of a child; the puberty of girls, and at that time the piercing 
of the ears, and nose, and the lower lip for the labret; the tattooing of both sexes; the burial of a relative; the building of a house; and the assumption of a predecessor's position and rank. The relative importance of the events varies according to the tribe. The Nootka place the puberty ceremony first; while the Tlingit and Haida make most of the ceremony attending the final placing of the remains of a deceased individual. Whenever one of these events takes place, the person who gives the ceremony assumes a new name, and displays by carvings, paintings, or more generally by dramatic representation, one or more of his inherited honors.

A man's renown is increased according to the frequency of the celebrations and the lavishness with which they are carried out. In order to give them at all, he must have inherited or acquired certain names and honors which he can publicly assume or display. The inherited ones come from his father's or mother's line, according to the tribe. Among the Nootka they come from either father or mother; with the Kwakiutl certain of them descend always from the father to the eldest child; among the Bella Coola they are willed, but usually in a fixed way; while in the northern tribes the more important ones pass from the uncle to his sister's son. Names and honors or crests among the Kwakiutl particularly may be secured by marriage. The fatherin-law bestows these upon his son-in-law, who passes them to his son. A man greedy for honors strives to marry well and often. It is not necessary in every case to actually take the woman in order to acquire the honors. In fact, if a daughter is lacking, a man may go through the form of marriage with a man's foot in order to perpetuate names and honors.

Not only are a certain number of inherited names or honors accuired through marriage necessary in order 
that these socially elevating ceremonies may be held; but the opportunities of acquiring wealth must exist. Chiefly, hunting and fishing grounds must be possessed. Generally, also, slaves and dependent relatives are required to assist in the accumulation of property. There is also much that may be done by skill and application. Canoes are excellent forms of property; and skill and labor alone will produce them. Successful hunting results in furs and skins, in earlier times, directly used for distribution, and in more recent times, readily exchanged for woolen blankets.

A certain element then comes by fortune, that is birth, and another by personal ability and activity. The inherited names are of little value unless the second element is added. They are only potential honors until they are assumed with lavish feasting and a distribution of wealth. But when the second element is added a man may greatly elevate his position during his life, and may bring about advancement for his descendants. This all soon fades and must be repeated in successive generations. By including neighboring tribes in ceremonies of this sort one's fame may be extended beyond the tribe. When a position has been acquired, it receives constant public recognition, since a guest's name is proclaimed as he enters a house, and a seat is assigned to him according to his rank.

Inherited Duties. There are many inherited public duties which do not bring the recipient especial renown. Among these, especially for the Kwakiutl, may be enumerated: public accountants of property, they are able to tell the amount of property out on loan at any time; tally keepers, who count and keep tally of blankets and other property when publicly transferred; and singers, who improvise and teach songs to those initiated in certain societies. Among the Bella Coola 
one man inherits the duty of enforcing the taboos and regulations in regard to the river. There are also many specific duties in regard to feasts, and the taking or preparation of the first fish or fruits of the season.

Chiefs. At the top of the social pyramid are the chiefs and those so close to them that they have reflected glory. In principle, the chief differs only in degree from the lesser individuals mentioned above. Like them he inherits a named house, with the right to decorate it with certain carvings and paintings; a number of feast dishes with names for them, and names for his canoes; certain traditional names for himself and the members of his family; family origin myths which are publicly shown in dramatic action; and other dignities. Besides, he inherits the duty of controlling the social unit of which he is the head.

Septs. On the Northwest Coast there are everywhere groups of considerable size who consider themselves related, at least to the extent of being descended from the same first ancestors. These extended families or septs are distinguished by names which serve as do our surnames in holding together the members of them. Theoretically, all chiefs are heads of such extended families only, but the chiefs differ in rank so that the head of the family of the highest rank in the sept, is chief of the sept. And the chief of the sept which stands the highest in the village, is chief of the village. Furthermore, the head of a leading village holds certain prestige in geographical sections. Among the Tsimshian particularly, there is a highest man in each of the four major social divisions or clans, and his position is, in a measure, a governmental one.

Just as among the common people there are varying but definite gradations of rank, so the chiefs are definitely graded. Among the Kwakiutl this grading of 
the chiefs is mainly, or perhaps entirely, on the theory of primogeniture. The oldest son is the head of the house; and the oldest son in the line of oldest sons in the sept, and village, and group holds the headship in each. That this is the real origin of the order of rank, it is not necessary to believe, but the Kwakiutl are accustomed to so interpret social distinctions. In this estimate of worth and standing the mother as well as the father is considered; therefore, a chief strives to marry as high as he can and thereby increase the position of his descendants. If he marries below himself he decreases the position of his family, and such a blot is remembered from generation to generation. In reality, this may be but the native way of explaining that certain families are less highly thought of than others.

Rivalry of Chiefs. While it is probable that the relative order in which the chiefs stand remains nearly the same from generation to generation, constant attempts are made by them to elevate themselves at the expense of their rivals. In this rivalry, methods similar to those employed by the common people to secure their advancement are resorted to. In connection with the same events in family life; birth, puberty, marriage, and death, the chiefs distribute property and give feasts, and carry them out on a still greater scale. Besides these general ceremonies, the chiefs seek opportunities for outdoing their rivals and putting them to shame. One form among the Kwakiutl is the giving of an oil feast during which olachen oil is served with other food, and great quantities of the precious fluid are thrown upon the fire, or allowed to flow on it from above. The flames leap up and often set the roof of the house on fire. The guest, who is the rival, must retain his seat by the fire, keeping his composure until the host gives the order to abate the flames, and to put out the fire which 
is burning the house above. However, if the guest believes that he has not been outdone; that at some time he himself has given a greater feast, he may refuse to accept the proferred spoon of oil and go to his house to bring a "copper" which he breaks and gives to his host, and thus "puts out the fire." The host not to be outdone

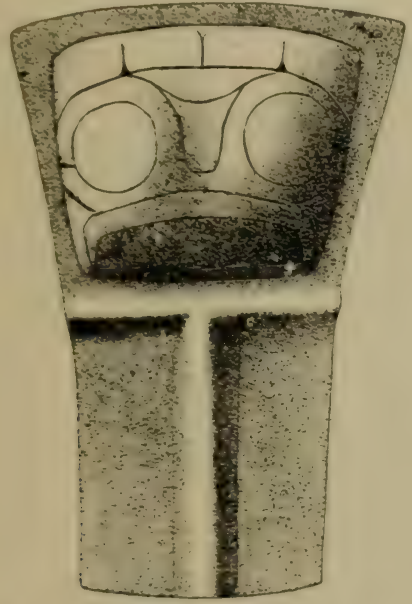

A Copper: Design, Horned Owl. must, in his absence, attach a copper to each of the four house posts. If beaten, the guest is "shamed," and must soon give a greater feast to recover his damaged position.

Another form of rivalry consists in breaking up coppers. One chief breaks a copper of well-known value and gives the pieces to his rival who must break a copper of equal or greater value and give in return the parts of both, or lose in prestige. A still more extreme act is to break a copper and throw the parts into the sea. Canoes may also be sunk and slaves killed. The coppers are shield-shaped with a rib running across the middle and from the center to one end. They are of native manufacture, the older ones being made of metal found in a free state near Copper River. Each has a name and a well-known history and its value depends on this history and the amount for which it has been sold.

This fighting with property generally takes place between chiefs who are traditional rivals. They may be chiefs of septs or of villages, or the leaders of more re- 


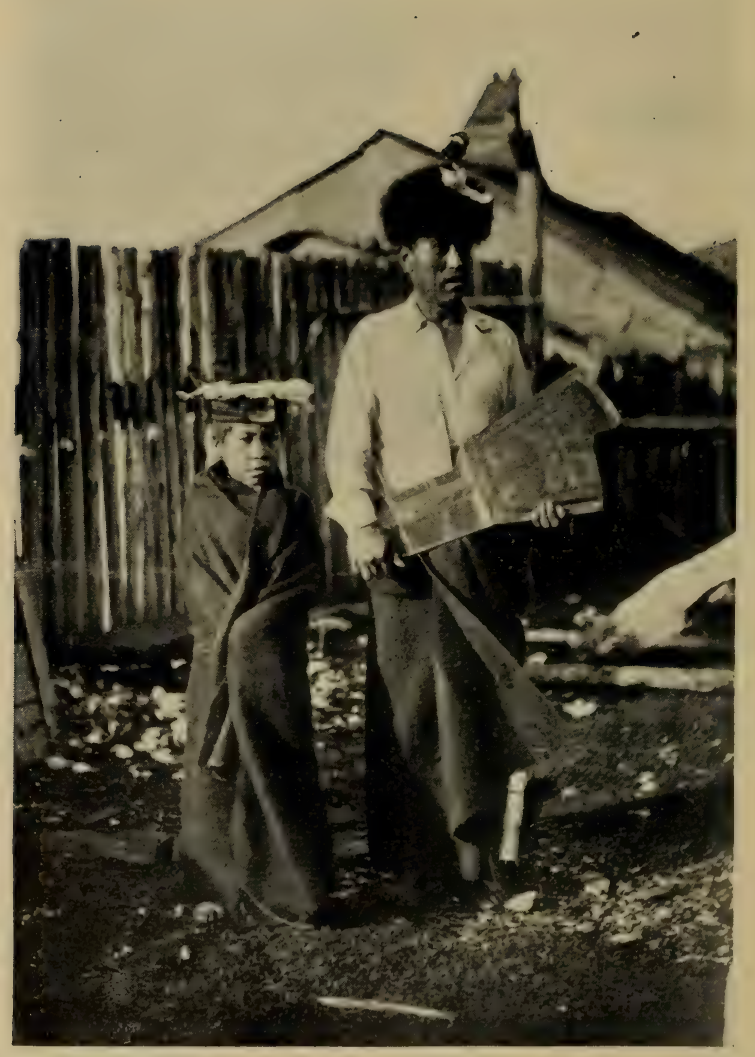

A Chief with his Broken Copper. Kwakiutl. 
mote groups. In all of these cases the chief acts for the members of his group who contribute very largely to the property used in such rivalry. It is certain also that for some of the peoples of the Northwest Coast the chief has a symbolic relation to his group, so that there is an emotional transfer to him of the power and prestige of the group. If he succeeds in raising his rank, he carries up the group with him. If he suffers insult, the group is correspondingly put to shame. The chiefs and their families are given a consideration similar to that formerly accorded royal families in Europe.

Linguistic and Geographical Groups. It was mentioned above that the winter villages are the largest political groups, and that the various villages have no formal political bonds between them. This does not prevent certain natural groupings according to language and contiguity. While a common language is not necessarily a bond of sympathy, it usually is one; and difference in language inevitably establishes a barrier. Ethnologists are inclined, however, to over-emphasize the linguistic barriers; for it can be clearly shown on the Northwest Coast that practically all elements of culture have become distributed geographically, with but little linguistic correlation. However, a common language can be easily made a rallying point for bringing about political cohesions. Beginning with the south the linguistic groups are: the Salish, the Nootka, the Kwakiutl; and on the west, the Haida and the Tlingit; on the east, the Kwakiutl-speaking Heiltsuk, the Salish Bella Coola, and the Tsimshian. A tendency to group according to topographical features is also evident. The dense forests and mountains of Vancouver Island separated the Kwakiutl into west coast and east coast people. If we accept the migration of the Haida to Prince of Wales Islands as recent, the Haida were 
isolated from their neighbors on all sides by wide straits; but among themselves they were divided into west coast and east coast, in their natural affiliations. Among the Tsimshian the grouping is more striking, since we have native names for the groups, and a strong feeling of political unity and differences. On the upper Skeena were the Gitksan, on the lower Skeena the Tsimshian proper, and on the Nass, the Niska.

Exogamous Divisions. Beside these natural linguistic and geographical groupings, there is another which appears to Europeans as artificial and strange. This is a grouping which controls marriage and descent. Such marriage-controlling and social divisions are, however, fairly common, occurring in Africa and Australia, and in America among the Iroquois and the southwestern Indians. There are two essential points to be observed, first that descent is recorded on only one side, the father's (paternal), or the mother's (maternal); and second, that all the members of one's own group are counted as relatives, and none of them can be considered as a mate in marriage.

The Haida until recently lived in many villages which were grouped according to location as west coast, and east coast, as well as south and north. Notwithstanding this geographical grouping, and quite regardless of it, all the Haida are divided into two parts; one called Ravens and the other Eagles. This division runs right through the tribe, because it runs also through every family. If the husband is a Raven his wife and children are Eagles. If he is an Eagle his wife and children are Ravens. Since, as has been said above, such social grouping is a well-recognized and widely distributed phenomenon, there is no reason to look for an origin of such groups in geographical distribution, or migration. The two essentials of such groups have been 
mentioned above; namely, descent in one line only, and an imputed relationship preventing marriage. In addition there may be religious, social, and political distinctions as well. Among the Haida the rank, names, ceremonial duties and properties, fishing rights, and house of a man must remain in his own clan. Since his children belong to the opposite clan, he chooses for his heir a nephew, his sister's son; and in order that the nephew shall become familiar with the duties and properties he is to inherit, he comes to live with his uncle as soon as he is old enough to leave his mother. In case of violent quarrels between the two clans a man's wife and sons adhere to their own clan and align themselves with his enemies, to whom they may even be expected to betray him.

The ceremonial connection of the clans among the Haida is with burial and the accompanying rites. The preparation of the body and its burial is done by the father's family who are members of the opposite clan, which is recompensed by a potlatch. There are no direct political functions of the clan since these pertain rather to the various "families" or septs. Since every sept belongs to one or the other of the clans, and all the members of a sept are members of the same clan, it is true that members of the same sept may not marry.

The Tlingit are also divided into two exogamous groups called Raven and Wolf. Some of the more northerly Tlingit call the Wolf clan Eagle. There is also a small third group which can intermarry with either the Raven or the Wolf clans. The Tsimshian proper have four clans instead of two; they are called: Eagle, Wolf, Raven, and Killerwhale. Each of these clans has a recognized head and, to a certain extent, he exerts political power. The Gitksan have three clans, Eagle, Wolf, and Fireweed. Among all these northern 
peoples descent is in the mother's line and persons always marry into some other clan.

The Bella Bella have four divisions in the north and five in the south, but these are not marriage regulating, merely local and social groups. They are equated, however, with the corresponding clans of their northern neighbors.

In the south, the Salish count descent, as we do, in both the father's and the mother's line, and inherit from both. Usually a man sought a wife in some other village and brought her to his own village to live. A man's son was his usual heir, but a man also inherited honors and property from his mother's people, as well as from his father.

Among the Kwakiutl it is thought that a method originally similar to the Salish has been influenced from the north. The names and positions of the heads of various septs and families are inherited by the oldest son or daughter and their descendants. There are, however, many names carrying social and ceremonial positions, which are transmitted by a man through his sonin-law to his daughter's child. A child other than the first born may belong to his father's or his mother's sept (numaym) according to the parents' wishes. Whether a child is assigned to his father's or his mother's numaym usually depends upon the relative rank of the father and mother, and the privileges at their disposal. It is a common practice, also, for a dying person to bestow his position by an expressed wish which is followed, if it be not too repugnant to the social customs. In certain of the noble Kwakiutl families an attempt is made to keep the privilege within the family by close intermarriage, such as half brothers and sisters, or the marriage of a man with his younger brother's daughter. 
The Bella Coola who are geographically in the region of clans and maternal descent have no clans; and, in order to strengthen the family power and prestige, are much given to intermarriage. Marriage between cousins or the children of cousins is not approved, but a union between the grandchildren of cousins is looked upon as ideal. It may be added that even among the northern tribes, where clans exist, the noble families intermarry generation after generation, but always on the father's side. It follows that the clan system in this region does not necessarily prevent inbreeding, it only diverts it from the maternal to the paternal line.

\section{Pubertȳ.}

The girls of the Northwest Coast at the time of puberty are, for a period, secluded, restricted as to their diet and movements, and must observe special taboos. There is considerable variation in detail as to these observances even in the same tribe. These practices, or similar ones, are nearly world wide among primitive people; and in America they are of particular importance, especially on the Pacific Coast, and quite beyond the special groups under discussion. The Indians of the upper Fraser River and southward far into California pay unusual attention to these observances.

There is a general agreement among the Northwest Coast tribes in placing the girl behind a screen; in requiring her to abstain from all food and drink for some days, and from certain foods for one or several years; and in guarding hunting, fishing, and gambling equipment, as well as fish and fish streams from her. The reasons assigned for these practices are of two sorts. The first is that the girl herself will be influenced by conformity, or lack of conformity with these regulations. Whatever happens to her at this time will affect her 


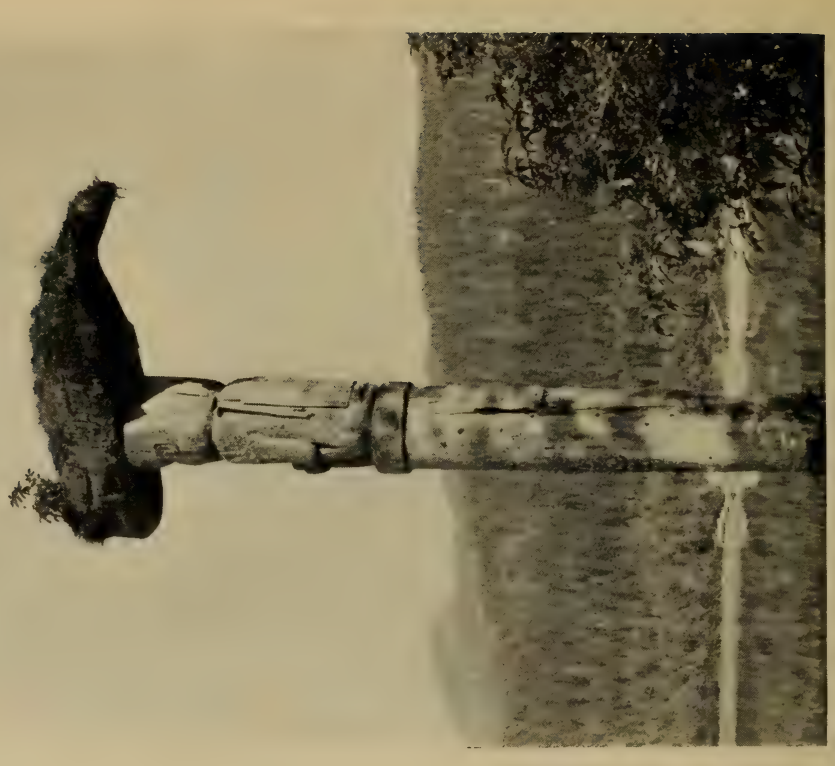

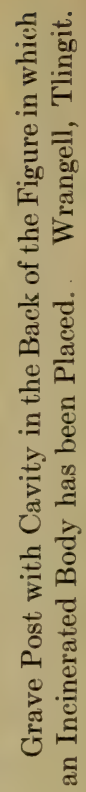

$\stackrel{\infty}{\infty}$

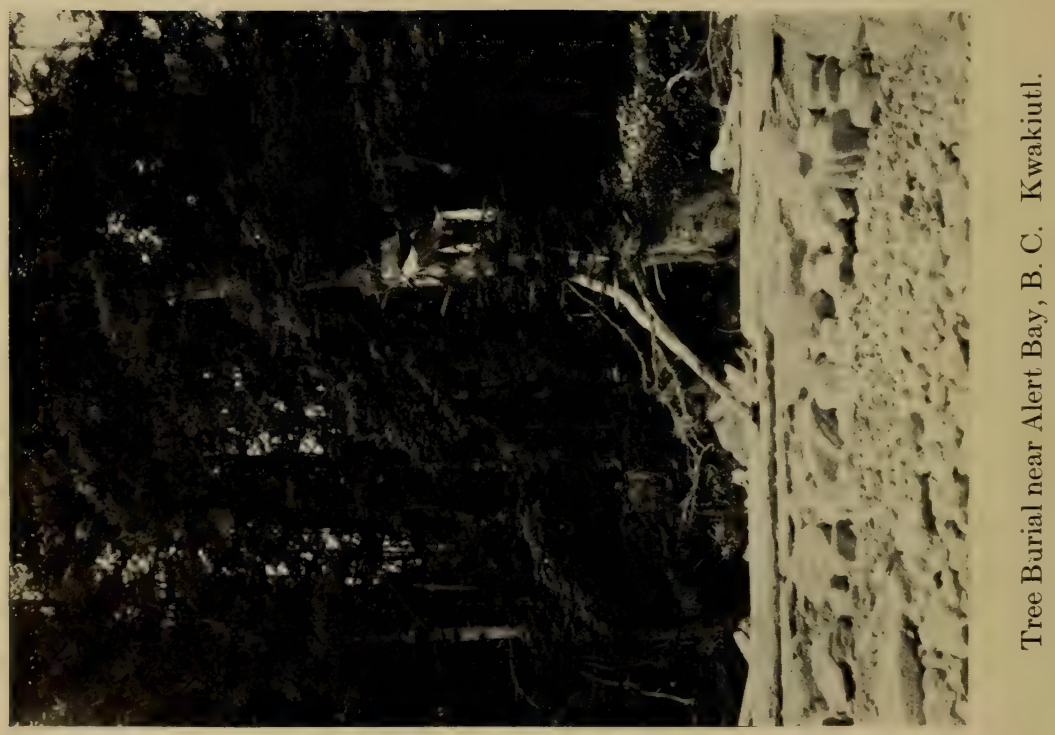


throughout her life. The second group of reasons relates to the effect of her actions on other persons and on things. A hunter, meeting her, would lose his luck. Salmon would fail to run if she saw them, or if she crossed the stream. Should she look at a running dog it would be stopped by her glance. In part, these reasons may be conceived of as inventions to frighten the girl into obedience. Behind some of them, no doubt, lies the belief that the girl during this time is endowed with great supernatural or magic power. It has been mentioned above that among the Nootka the coming of age of a daughter is an occasion for-giving a potlatch of special grandeur.

\section{Burial Customs.}

Tree Burial. The Nootka and the southern Kwakiutl formerly resorted chiefly to tree burial. The bodies were folded and placed in large-sized boxes which were taken into tall timber and placed high up in a large tree. Care was taken to select a tree inaccessible because it leaned out over a chasm or the water, and also to cut away all the limbs below the body so that climbing the tree thereafter would be difficult. The place resorted to was some distance from the village, often on an island. Bodies were also placed in caves, provided suitable ones were available. Among the Nootka the burial caves belonged to the more important families. The Kwakiutl viewed burial in the earth with considerable horror when contact with Europeans first brought the custom to their notice but they have now adopted the practice.

Canoe Burial. The Salish tribes of Washington often used canoes as receptacles for the dead and their belongings. These were elevated on logs or placed in trees to get them above the reach of animals. 


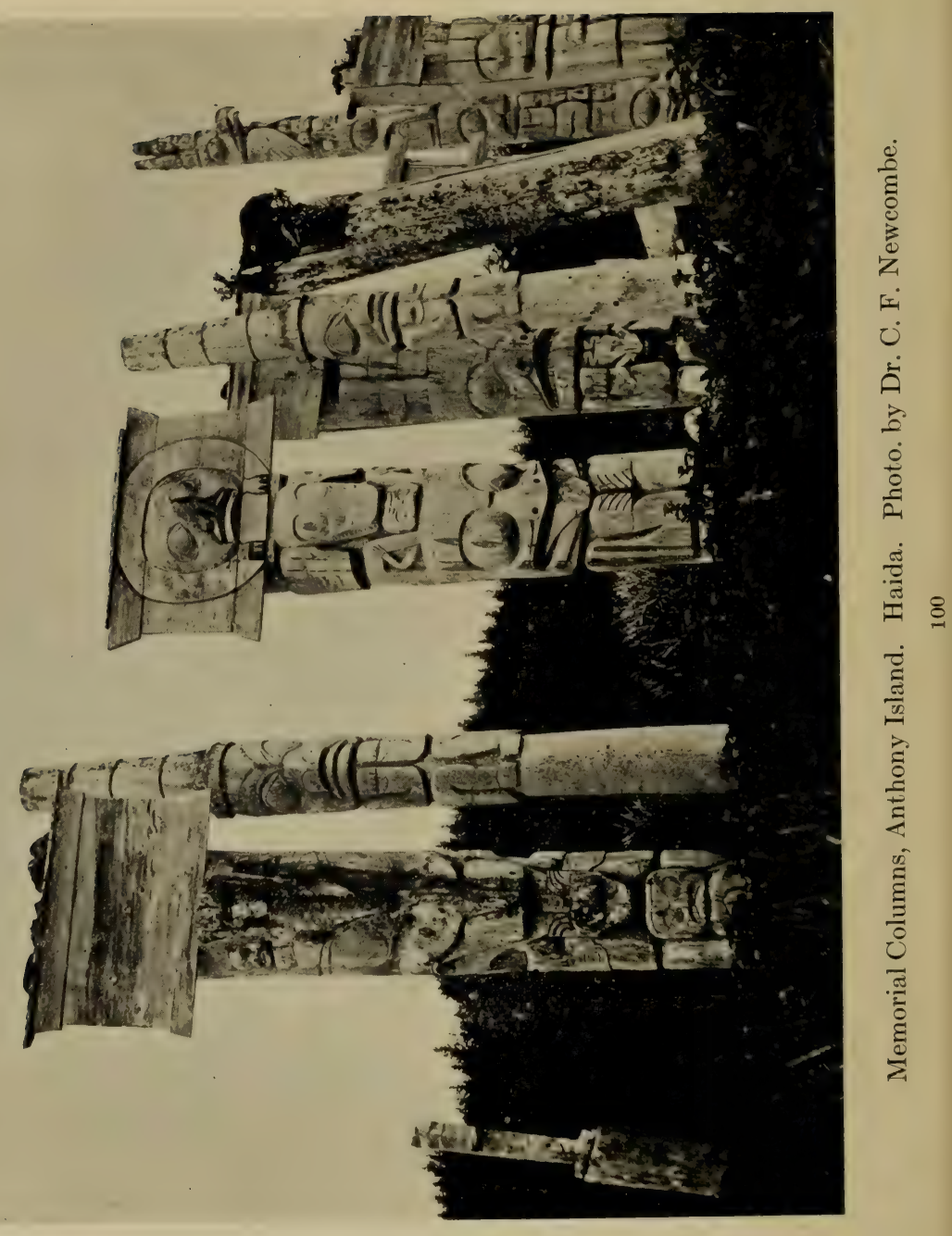


Cremation. The Tsimshian burned the dead except for the heart which was removed and buried. With shamans, however, the internal organs were buried, and the body placed in a grave house above ground. The Haida and Tlingit also burned all but the shamans whom they placed in grave houses in some isolated place. The bones, after the cremation, were gathered up and placed in elevated boxes or in monuments.

The intimate personal belongings of the deceased were burned, or, in more recent times, placed near the grave.

Memorial Columns. It was the practice of all of the tribes to erect a monument near the burial place of the more prominent dead. Usually this consisted of a wooden carving representing the principle crest of the deceased. Recently similar carvings made in stone have been substituted for wooden ones. The burial among the northern tribes is always carried out by the family of the father, persons who are not of the same clan as the deceased. Among the Tlingit and Haida, those who bury a man would of necessity be members of his wife's clan. The Kwakiutl must have people who are not related to them cut the hair of the mourners. The performance of such duties involves payment, which is accomplished in public and with a feast; that is to say, it is potlatch occasion. Among the Tlingit it is the main occasion for giving a potlatch, and takes place when the remains are placed in their final resting place, and the burial monument is erected. Because the work is done by the opposite clan, they are the recipients of the distributed property.

\section{Marriage.}

Selection of Mates. The choice of a mate is subject to varying restrictions, according to the tribal customs, and the social standing of the individuals concerned. 
Among all the tribes, it is almost indispensable that marriage should be between equals in rank. While this is the ideal, some accommodation to the supply and demand of mates must be permitted; especially where the number in the tribe is small. In the south, among the Nootka and Salish, near relatives were avoided, whether on the father's or the mother's side. There was a tendency, moreover, among the mainland Salish to marry outside the village. In the north, the Haida and Tlingit are divided into two matrilineal groups which were exogamous; therefore, a man always marries into his father's group and never into his mother's. The Tsimshian, being divided into four groups, are not compelled to marry into the father's clan, since there are two others which are available.

The Kwakiutl of Vancouver Island and the neighboring mainland reckon descent usually in the father's sept, and marry into some other. There is, however, a counter tendency, especially in the higher families, to intermarry in order to keep the crests and privileges within the sept.

The Bella Coola, in the middle region, do not have matrilineal clans, and there are no exogamous regulations. On the other hand, certain families are accustomed to intermarry in order to concentrate social possessions and social position, rather than suffer their dispersion by marriage with outsiders. Since rights and honors, in addition to those inherited, are mainly obtainable through marriage, a father eager to improve the position of his descendants will marry his daughter, even before she reaches puberty, to several men in succession. The honors so accumulated go to his grandchildren regardless of which particular man is their parent. Marriage between cousins or children of cousins is not allowed, but the most favorite marriage is be- 
tween grandchildren of cousins. Certain related families continue intermarrying for generations.

While, as has been said above, the northern tribes must always avoid the mother's group there is no such regulation in regard the father's relatives. The conventional marriage for a Tsimshian youth is with his mother's younger brother's daughter. The rule that equals should mate, greatly reduces the choice of the few high families so that constant intermarriage on the father's side becomes necessary. It was formerly the custom for the head chiefs of two of the more important Tsimshian tribes to marry each other's sister, generation after generation. So complicated are the various social conditions among the Tlingit, that for a member of the higher aristocracy, the choice of a mate is sometimes reduced to two or three individuals.

Equality in age is not so much considered. Among the northern tribes, where the sister's son succeeds his uncle, inheriting property and privileges from him, he is expected to marry his uncle's widow. When he becomes older, however, there is an opportunity to secure a bride much younger than himself. Such inequalities of age are looked upon with favor.

Marriage Customs. There is considerable uniformity in the method of carrying out marriages. The custom seems to have been general for the bridegroom's relatives to approach the bride's family, in a formal way, with presents or promises of presents. A certain degree of hesitation is ordinarily shown by the bride's family, which may take the form, as it does with the Salish in the south, of keeping the bridegroom waiting and fasting for some days. The Nootka and Kwakiutl have certain ordeals peculiar to the particular family, which must be successfully passed by the groom, or by his representatives. One form is to compel the bridegroom 
to pass by a very hot fire. There is often also some bickering over the value of the presents offered; not of a mercenary character, however, but to accentuate the high standing of the parties concerned. The acceptance of the presents by the bride's family is followed by return presents of equal or greater value. These by the Salish are delivered within a few days to the village of the bridegroom where the bride is taken to reside.

In the case of the Kwakiutl, the bride's father announces at the time of the wedding that he will give his son-in-law certain property and honors. These are usually not delivered until a child is born to the couple, and often, not until the child is old enough to be initiated into the ceremonies. The amount given by the bride's father is sometimes five times that received from the bridegroom, varying according to the number and sex of the children. The Kwakiutl consider that this payment dissolves the marriage. The wife, if the first one, ordinarily continues to live with her husband, but with a greater degree of independence, since she is free to return to her home if she wishes. If her husband is ambitious for honors and able to pay for them, he makes presents again to his father-in-law, renewing his marriage. In due time he receives in return more than he has given in property, and additional names and honors. In all these cases the transfer of property takes place at a public gathering where the witnesses are feasted. The property received is distributed to the husband's sept within a day or two. The son-in-law benefits, not in property, but only in the new and higher honors which he has received. These, however, in all ordinary cases he transfers to his son, or his daughter's husband, in the same manner he himself received them. 
The Haida mother often makes an engagement for her son or daughter while they are still quite small and gives it ralidity by a present of blankets. The family of the boy takes the initiative among the Masset, and the family of the girl among the Skidegate. When the ceremony takes place, the speeches made by the boy's relatives praise the girl and her family, while her own spokesmen belittle her and her abilities. This procedure is the reverse of that among the Nootka, where each party bestows praises on his own.

\section{Games.}

The Northwest Coast people are quite addicted to gambling. The most popular game is the well-known and widely distributed one of guessing by the expression of the opponent's face where a marked stick is concealed. The objects necessary are a number of sets of sticks about ${ }^{3}$ of an inch in diameter and 5 inches long. The sticks of the same set are painted with the same pattern except the "ace" which is unmarked. Each set has a bag and a larger one holds the various sets of the owner. There is a piece of skin on which the sets of sticks are laid out, a mat on which the playing is done, and a second piece of hide on which the sticks are displayed while the guess is being made. The opponents sit facing each other. The first player selects one of his sets of sticks, wraps them in cedar bark, and divides them into two bundles which he places before himself. His opponent then guesses, by a study of the player's expression, in which bundle the "ace" is concealed. If he guesses correctly, he takes the play, but if not, the former player continues. When one side has reached a count of seven, four bundles are made instead of two, and the player wins the final point only if the guesser misses it after three trials. such odds greatly prolong 
the game. This game varies as to the objects used, but the main point that of guessing from the opponent's expression and reactions is the same.

There are in addition, dice games, shooting at a mark, and a form of quoits. The stones used in the latter game are frequently found near the village sites. The Northwest Coast people, in common with those all over the world, have string figures or cat's cradles.

\section{W ARFARE.}

While many of the winter villages were located with a view to comfortable living rather than defense, certain other sites were chosen with an evident desire for security from attack. Ordinarily, a point of land was occupied so that the only approach was by a narrow passage-way which could be cut off by means of ditches and stockades. In most instances these forts could be reduced by a few days' siege, but the Indians were not accustomed to long continued and tenacious fighting.

Armor. There were two sorts of armor used. One kind was of heavy skin, made of double thickness and worn like a shirt. Some were long, reaching nearly to the knees, and others only to the hips. They were generally sleeveless, but some specimens have a sleeve for the left arm, the right arm being free for use. One of Captain Cook's men amazed the Nootka by shooting a musket ball through one of these skin shirts folded six times.

The second kind was composed of sticks, either flat or round, placed vertically and held securely by stout cord twined around horizontally. It was worn like a waistcoat, tied in place with leather strings on the right side.

In addition, there were wooden pieces for the neck and face reaching up under the eyes, and above this, a 
helmet. Such armor gave very excellent protection from weapons of that period.

IVeapons. For offense, bows and arrows were sometimes employed. Short spears were also used, both for thrusting and throwing. The Tlingit had knives, twoedged with a carved handle of wood or bone, or twoedged and pointed at either end with a hand grip considerably to one side of the middle. Formerly, they were made of bone, and probably also of native copper. These knives were customarily worn suspended from the neck, or thrust into the belt. Clubs were also employed some of which were of the bones of whales, and others of wood, long and heavy enough to crush a skull. Most curious of all are the pickaxe-like weapons, men-

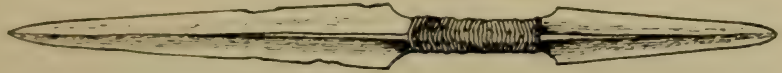

Double Ended and Double Bladed Knife, Made of Bone of Whale. Tlingit.

tioned by Captain Cook, a specimen of which from the Tlingit is in the Museum collections. Mention may also be made of a peculiar shaped stone club generally referred to as a slave killer.

Motives for Fighting. The occasions for fighting were chiefly two: revenge, and the securing of slaves. The feeling for a just balance, life for a life, injury for an injury, was strongly developed and was active between families, villages, and larger groups. In several respects the Indians' views of such matters are quite unlike our own. In recent times we have come to feel that retaliation for death or injury should fall upon the guilty individuals, while the Indians are as well satisfied if they take revenge on any member of the same group, or a person living in the same region from which the injury 
came. An example of this is seen in a recorded account of the Kwakiutl. A canoe with its passengers, one a chief, failed to return from Victoria. Evidence pointed to indulgences in liquor and the resulting inability to properly navigate the boat. A war party went to the vicinity of Victoria and killed the first party of Indians found in that region while they were sleeping. The

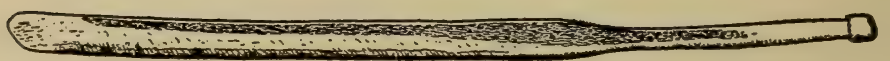

War Club Made of Whale's Rib. Tlingit.

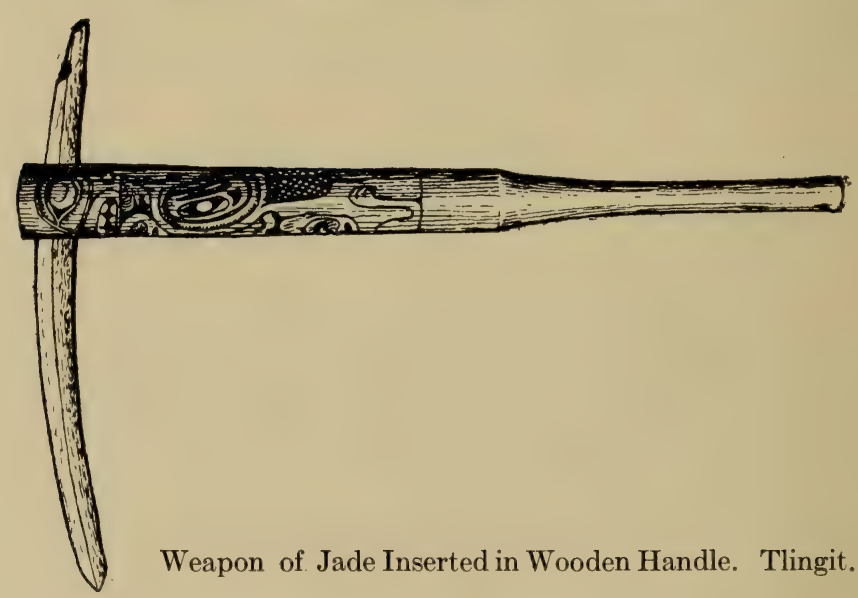

motive is rather clearly shown to be the satisfaction afforded the living relatives and some assumed benefits thought to accrue to the souls of those who have met a violent death.

As might be expected, where rank is so important as on the Pacific Coast, a life for a life is not always satisfactory. The Tlingit, when a man had been killed in a village, are said to have conferred as to the man's 
worth and then to have chosen from the offending group a man of equal value. This man was publicly called upon to come forth and be killed. The man actually guilty, being of too little worth to satisfy justice, entirely escaped, or settled matters with the family of the man killed in his stead.

Methods Employed. From the accounts available the usual method of waging war was as follows: The proposal for a war expedition was made in a public assembly by some man of influence. It was then determined whether other groups should be invited to coöperate with them, and a time was set for the expedition to leave. The warriors and their wives underwent purification; in the south, at least, this consisted of frequent bathing followed by scrubbing with boughs, fasting, and continence. The canoes were raised up, scorched, and freshly rubbed on the oustide. Certain religious and magical acts were performed to secure good luck. The wives were required to follow established rules of conduct in order to bring good fortune to the party. Travel was always by canoe, the crews of which were organized, each having a man provided with kindlings for setting fire to houses, one with ropes for securing slaves, and watchers to remain with the canoes. Due care was exercised that information should not reach the enemy. The arrival was timed for the evening, and the attack for the morning about dawn, that the victims might be caught asleep. In the dusk of the evening of arrival, a small canoe was sent to do scouting. The exact number and position of the houses were noted and the attack planned accordingly, each canoe crew being asisigned to a definite house. If revenge were the motive, men and women would be killed, but if the expedition were for the purpose of securing slaves unnecessary slaughter was aroided especially of women. 
Trophies. As trophies, the whole head was usually cut off. Later the Tlingit, at least, skinned off the scalp, which included the ears as well as the hair. After a dance over them, the heads were placed on poles and the scalps were sometimes fastened to the tops of caps which were worn in ceremonies.

War deeds gave a man an honorable position and entitled him to a newly bestowed name among the Nootka. Such honors were not generally transmitted by gift or inheritance, as was the case with rank in general. In most cases, peace might be made by paying sufficient property to bring about a balance of the estimated value of those killed on either side. 


\section{Chapter IV.}

\section{RELIGION.}

In dealing with so difficult a subject as religion it is well to take up various aspects of the subject in detail. One profitable division of the subject is into the beliefs concerning the universe on one hand, and on the other, the specific acts and general conduct which seem to have religious motives. The elaborate ceremonies of the Northwest Coast, which at first might be thought of as mainly religious in character, prove on analysis to be largely dramatic, with the social and artistic features fully as prominent as the religious ones.

Religious Beliefs. Religious beliefs are concerned with the present, the past, and the future. Those regarding the past and the origin of the world are largely speculative, and are generally formulated in myths which do not necessarily have much connéction with human conduct. Those dealing with the future are also speculative; and relate particularly to the persistence of personality after death. The conception of the supernatural world as constituted at the moment, however, is one of the greatest importance, since it very greatly influences daily life.

Supreme Being. There is no evidence that a belief in a supreme being is general, but among the Haida and the Bella Coola, it appears that such a definite conception does exist.

Haida Deities. The Haida refer to this being as the Power of the Shining Heavens. It seems that human beings have no direct personal relations with this being, who is conceived of as the source from which all the other minor supernatural beings derive their power. It is with these secondary deities that man deals. There are houses believed to be suspended from the sky, in one 
of which lives Wigit who keeps account of all human beings, and, who when a baby is to be born, reaches behind himself and pulls out a stick, the length of which regulates the duration of the child's life.

Of the supernatural beings on the earth, the Creekwomen are of great importance. Each stream is believed to have a female divinity whose abode is at the river's source. She controls the stream and all the fish in it. One of these, Djilagons by name, was also an important mythological character. Underneath the Queen Charlotte Islands which constitute the Haida world stands "the sacred one standing and moving." His infrequent movements produce the earthquakes. Thunderbird is responsible for lightning and thunder.

Besides these beings, which to our way of thinking are purely imaginary, the Haida consider that practically all fish, birds, and land and sea mammals are beings similar to ourselves, but possessed of varying degrees of supernatural power. All of them are capable of taking the human form; or better, they possess a human form, and assume their other forms when coming among men. Of all living things, the killerwhales are the greatest. They are believed to live in villages under the sea, usually near some point of land. These under-sea villages are definitely located and named. The killerwhale's body is the canoe in which he is accustomed to travel. There are also salmon people, herring people, and on land, grizzly bear people, land-otter people, etc. It is not always clear whether the supernatural land-otter people, for instance, are distinct from the mere animal or not. Probably there is much confusion in the native mind on this subject. It is important, however, to keep in mind that the Indian attitude toward animals is extremely different from our own. Under the influence of Christianity, we have come to look upon animals as 
soulless beings, strictly mortal, and governed by instinct rather than by intelligence as human beings are supposed to be. The people of the Northwest Coast believe that animals have souls which are immortal and which usually become reinearnated. They are considered practically our equals in general intelligence, and to surpass us in the particulars for which the animal in question is especially noted.

Among the Haida, these animals also are divided into two divisions: Ravens and Eagles. The killerwhales are differently marked so they can be distinguished: the Eagles having a white patch at the base of the dorsal fin. Many of the taboos and customs observed in hunting and fishing are adjustments to bring about social harmony between men and the "other peoples" used for food. One needs to realize that these are not, to the Indian's way of thinking, mythological beings, but real beings upon whose good will they are dependent.

Bella Coola Deities. The Bella Coola conception of the supernatural is somewhat similar, but rather more definitely systematized. There are five worlds, one above the other, ours being the middle one. On the highest, toward the east is the house of a woman, all powerful, but disinterested in worldly affairs. On the second world, the one directly above us, is the House of Myths. In it the principal deities live. The most important may be considered the supreme being, as far as the actual control of the world is concerned. He is appealed to in prayer by men. Often he is thought of as traveling in the sun, but he is by no means inseparable from it. He makes a soul for each of those about to be born: one of the minor gods fashions its face; and a goddess rocks it, and sends it below to be born. In a like manner all the animals are made and sent below for 
birth. In the house of myths also lives the mother of the flowers, who each spring gives birth to the plants in the order in which they appear on earth. Deaths are determined there as well as births. Minor deities are charged with the control of the secret ceremonials which are held in the winter time upon the earth.

Gods of the Kwakiutl. The Kwakiutl have the same notions as the Bella Coola about houses in which the supernatural ones live, but unlike the Bella Coola, the Kwakiutl make the mysterious, heavily forested inland region, rather than the upper world, the home of these supernatural beings. Most frequently mentioned is the house in the north where the cannibal spirit lives who gave the Kwakiutl their most prized ceremony, and who is believed to still initiate all the candidstes received into the Cannibal Society. Of more general religious significance is another house from which a different type of winter ceremony is derived. Incidentally, it appears that in this house the souls of all the plants, and perhaps the smaller animals also, dwell. Since one of the performances held in this house is that of giving birth, it is probably believed that from this house all generation of men, animals, and plants, takes place. Besides these two houses somewhere on land is one under the sea belonging to the killerwhales who are the greatest hunters of sea life. The Kwakiutl agree with the Haida in considering all animals as potentially human-like, and capable of assuming the appearance of men. The mountain goats, like the killerwhales, have a house in which they live, as men do. Even the one domesticated animal, the dog, may take human form.

It is clear that the deminating religious conception is that bodies of men, animals, and plants, are but the kouses, canoes, or shells in which souls dwell; and that these souls have a great range of action outside of the 
"habitations" in which they are ordinarily found. As an example of this, some of the stories about salmon are of interest, especially as salmon were most vitally connected with daily life.

Salmon People. A young prince was scolded by his mother for taking a certain dry salmon to give to his hungry slave. The prince was grieved and went down by the river. There a canoe came which he entered and was taken far out to sea. He arrived at a village where the carvings were of the spring salmon who lived there. The chief had been ill because the prince's mother had kept the dry salmon for two years, and that particular salmon was his body. The slave's eating it had in some measure made him better, and from gratitude he had sent for the prince. Whenever the prince was hungry he was instructed to club one of the children playing outside. The child immediately became a spring salmon. The prince was charged to be sure that all the bones left after his meal were put in the fire. If this is done to the bones of the salmon, they are alive again in their own country. Dry salmon must not be kept beyond the next running season, for otherwise they are not released by being eaten and the burning of their bones. This is the Tsimshian practice. The other tribes place the bones and entrails in the river. When once the prince overlooked an eye, a child complained that one of his eyes hurt. As soon as the prince found the missing eye and burned it, the child's eye was well again.

In spring the salmon chief, now fully recovered, sent scouts to the Skeena and Nass rivers to see if the cottonwood leaves were floating in the river. As soon as they were found, a journey was made to all the villages of the salmon people, and they were notified. Each variety of salmon had its own village from which the canoes set out in proper succession to go to the rivers 
where they appeared to the fishermen in their fish form. The chief of the spring salmon went to the shaman's net. After his names had been called over him he was cut open and was used in a feast from which all who were unclean were excluded. All his bones were put in the fire; and those who had eaten took a drink of fresh water. The prince was found in this chief salmon's stomach and rapidly grew to his former size. He instructed the people as to the things which must be observed in regard to salmon, and finally returned to live with the salmon people.

Such conceptions of an animal world, closely interrelated with human beings, furnish much of the religious life and emotional atmosphere of the Northwest Coast.

\section{Religious Practices.}

Ceremonial Cleanness. In response to the conceptions outlined in the last section, certain efforts are made to keep on good terms with the supernatural beings. Many of these observances may be grouped under cleanness. The supernatural ones are supposed to be very sensitive in regard to odors. In part, this may be an entirely natural and practical observation in so far as it concerns game animals. Physical cleanness is produced by frequent bathing. For certain occasions, the baths are in the sea, but the most beneficial are in fresh water lakes. After the bath, the body is scrubbed with hemlock branches, often until the blood runs. Such baths are taken night and morning for four days or in four different lakes four times each. A man who undertakes ceremonial duties must practise continence for days and sometimes weeks in advance. Women, unless 'well past middle age, are always of doubtful cleanness, and are sometimes excluded from ceremonies as a matter of precaution. Going without food and 
water is thought to contribute greatly to an acceptable condition and for the same purpose the stomach is emptied by emetics.

While these efforts to secure personal purity are sometimes so that game, viewed as supernatural, will not be offended and driven away, they also render the body an acceptable abode for any spirit that may wish to possess it. Once a spirit looking through a smokehole saw a Tlingit youth nearly dead from his fasts, but so clean as to be transparent like glass. In the Plains region, and elsewhere, similar means are pursued, but the Plains people consider that the supernatural ones take pity on the man's suffering, a concept not common on the Northwest Coast.

Offerings. Offerings of food, especially of fat, are made. For water beings, the offerings are dropped into the sea, but for most other beings the gifts are placed in the fire. These offerings are not of any considerable bulk or value and do not seem to be given with an idea of purchasing favors or goodwill. They are rather forms of social politeness.

Taboos. There are many taboos which must be observed for fear of evil results. Naturally, many of these have to do with salmon and fishing. Among the Tsimshian only mussel shells could be used for cutting salmon and among all the tribes metals were at first thought to be offensive. Mackenzie and others of the early travelers found it difficult to buy fresh salmon, the Indians fearing the fish would be cut with metal knives and cooked in metal dishes. Breaking of a taboo would "shame" the salmon and they would cease to run up the rivers.

The first salmon taken each year receives especial treatment. The Bella Coola put it on a mat with its head on a pillow and offer it a piece of cedar bark. 
Afterward, eagle down is strewed on it and it is carried to the house and roasted. The Kwakiutl pray to the first salmon caught each year and eat them immediately in a feast to which the men of the sept are invited.

The Nootka are accustomed to bring into the house a bear which has been killed, place it in a sitting position, put a hat on it, and sprinkle it with eagle down. It is offered food and invited to eat it. The Tlingit also carry the grizzly bear's head into the house and put red paint and eagle down on it.

\section{Shamanism.}

There are certain individuals among all peoples who are supposed to have unusual and supernatural powers. These are generally called shamans by ethnologists. Their extraordinary powers are believed by the Indians to come from the aid of supernatural beings who, at particular times, possess the shaman and speak through him. Among the Haida and Tlingit a powerful shaman has a considerable number of spirit helpers for each of which there is a special mask. When the influence of a particular being is felt, his mask is worn, and the shaman speaks the language the spirit is supposed to use. In the north the calling of the shaman is usually inherited, passing from the uncle to his nephew. The dying man tells his heir what spirits are to inspire him and gives him the necessary instructions. Afterward, the shaman increases his powers by obtaining additional spiritual assistants. The uninitiated, at least, believe that in all cases the shaman acquires his power through a visitation or seizure by a supernatural being. The man's soul is taken away and visits the abode of his helper and receives magical power and gifts. The body of the person may be lying in a trance in the meantime in his 
own house. In some instances, the spirits seek the man and he may become a shaman against his will.

Curing Methods. In the treatment of the sick, a shaman, after dancing with his rattle, is supposed to see the cause of the disorder. This may be some natural or

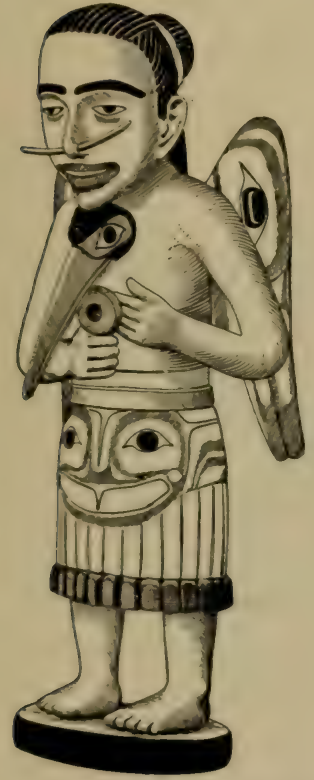

Model Representing a Shaman with Raven Symbols. Haida. supernatural object lodged in the body which becomes visible to the shaman. It may be that the patient has passed behind a shaman who has swallowed his soul. In that case the dancing shaman would be able to see the sick man's soul in the other shaman's stomach. The soul of the patient may have left his body and gone to the graveyard or away into the woods. The second step, the curing one, requires that the foreign object be removed from the body, or that the soul be restored, if it has wandered away. In the first case, sucking is resorted to and the object is produced from the shaman's mouth. In the second case, the shaman goes where the strayed soul is seen by him and catches it between his palms. He displays it and places it on the patient's head.

Other Duties. It is not only in the curing of the sick that a shaman serves the community. Some of them are able to foretell events and to see what is happening in distant parts. Every war party includes a shaman who by his supernatural knowledge warns of danger and points out favorable times and places for 
attacks. The shaman, by catching or destroying the souls of the enemy, makes the killing of their bodies an easy matter. A powerful shaman tells where a stranded whale is to be found, or he may be able to produce their stranding and to influence the run of fish.

Peculiar Dress. . His dress is peculiar, particularly in the matter of his hair, which is never cut or dressed in any way. He has a bone head-scratcher suspended from

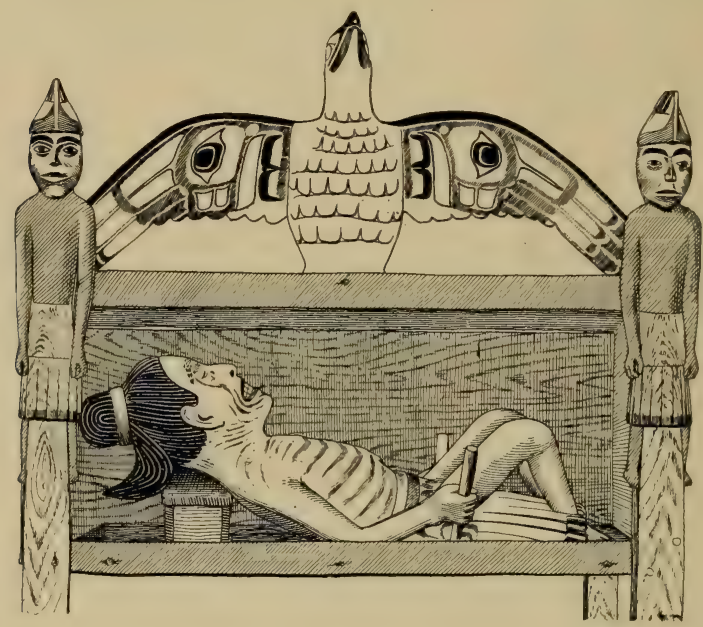

Model of a Shaman's Grave Box. Haida.

his neck and a tube through which he blows on his patients. He also wears a long bone through the septum of his nose. He displays his power on various occasions, particularly by walking through fire, and often enters into contests with rival shamans when their respective helpers engage in combat. There are both women and men shamans.

When a shaman dies, he is buried by the northern tribes, not burned, and supernatural power remains 
about his grave house which is at a distance from the village. His soul goes to a special abode, usually in the sky. Among the Tlingit, shamans rival the chiefs in the power exercised over the people.

\section{Winter Ceremonies.}

Throughout the Northwest Coast there are secret societies which in the winter give dramatic presentations of myths. To the uninitiated, the actors appear to be possessed by supernatural beings and to do very miraculous things. From their viewpoint, at least, these ceremonies are chiefly religious. Those who are engaged in the performances prepare the properties, rehearse with care, and endeavor to act so realistically as to deceive their audiences. From their viewpoint, these occasions are dramatic, or theatrical, and belong as much with art as religion. But since the acts presented are dramatizations of the acts of supernatural beings in the mythical period, or manifestations of present-day supernatural power, the religious element may be considered as predominating.

In their main features, these winter ceremonies are common to the Nootka, Kwakiutl, Bella Bella, and Bella Coola. The time of holding must be in the winter, beginning at a rather definite moment when supernatural beings and powers are thought to arrive and remain in the villages. The moment of their arrival is made known by the sound of whistles which, in theory at least, the uninitiated think is made by the spirits of the winter ceremony. These whistles are heard whenever, during the ceremony, possessed persons are about or are active. since feasting and distribution of property is constantly taking place, the social features are especially pronounced. The events are planned and controlled by 
those in authority especially as to the considerable provisions, both for food and gifts, which are necessary.

The ceremonial features are built up around the belief that one or more persons, usually young, are taken away to the homes of the supernatural beings who give them songs and instruction, and possess them, causing them to act in an insane manner. When they reappear they must be captured and restored to a normal condition. They are, however, subject to seizure in the future whenever the ceremony is held for others, or when anything suggests to them their supernatural experiences.

Kwakiutl Ceremonies. Full information concerning the secret societies is available only for the Kwakiutl. Each year that the ceremony is held it is initiated by an announcement made by some man that he wishes his son to assume membership in the society to which he holds a right. This privilege of membership is usually secured through marriage. A man's father-in-law at the time of the marriage promises to give him his place in a secret society. This membership, however, is generally held in trust for the children of the newly married couple. When a son is of proper age to take the place, his father asks that the promise be fulfilled. At this time also the father-in-law returns to his son-in-law the payment made at the time of the marriage with additional property, often four or five times the value he received for his daughter. The chiefs consult to make sure that the man and his relatives have sufficient wealth to carry through the ceremony properly. The whole tribe is convened and notice is given of the prospective ceremony. The winter dance pole is brought in and the man and his father-in-law announce the amount of property which is to be transferred. The people are directed to purify themselves during the succeeding 
four days by bathing in the sea in the early morning. After the bath, they rub themselves with hemlock branches. All relations between the sexes must cease. The reason given is that the spirits of the winter ceremonies are about to come to the village and that human odors are offensive to these spirits. As the assembly breaks up, the young man who is to take his place in the society disappears with a characteristic cry. The people are reminded that he has been taken by the cannibal spirit to his home in the north where he will be initiated by the supernatural people living there. $\mathrm{He}$ is expected back at the end of four days at which time the people are requested to reassemble.

Their Societies. The house of the winter ceremonies is cleared out and prepared for the celebrations. After the four days have passed, the people are called to come to this house by special messengers. It will be remembered that when the northwestern people come to a feast or formal assembly they are always seated according to rank by families, septs, clans, tribes, etc. During the winter ceremony they are differently grouped, according to the societies to which they belong. These societies fall into two main divisions; the more important being called the seal society is composed of all the dancing or drama-acting bodies. The various societies forming the seals are graded in importance, at their head being the hamatsa or cannibal society. The less important division also consists of graded societies bearing animal names in which the people are grouped according to sex and age. Between these two groups there is much rivalry and assumed enmity. Not only are the people differently grouped during the winter ceremony, but each individual has a different name by which he must be called during this period. This is, no doubt, a recognition of what is believed to be a changed 


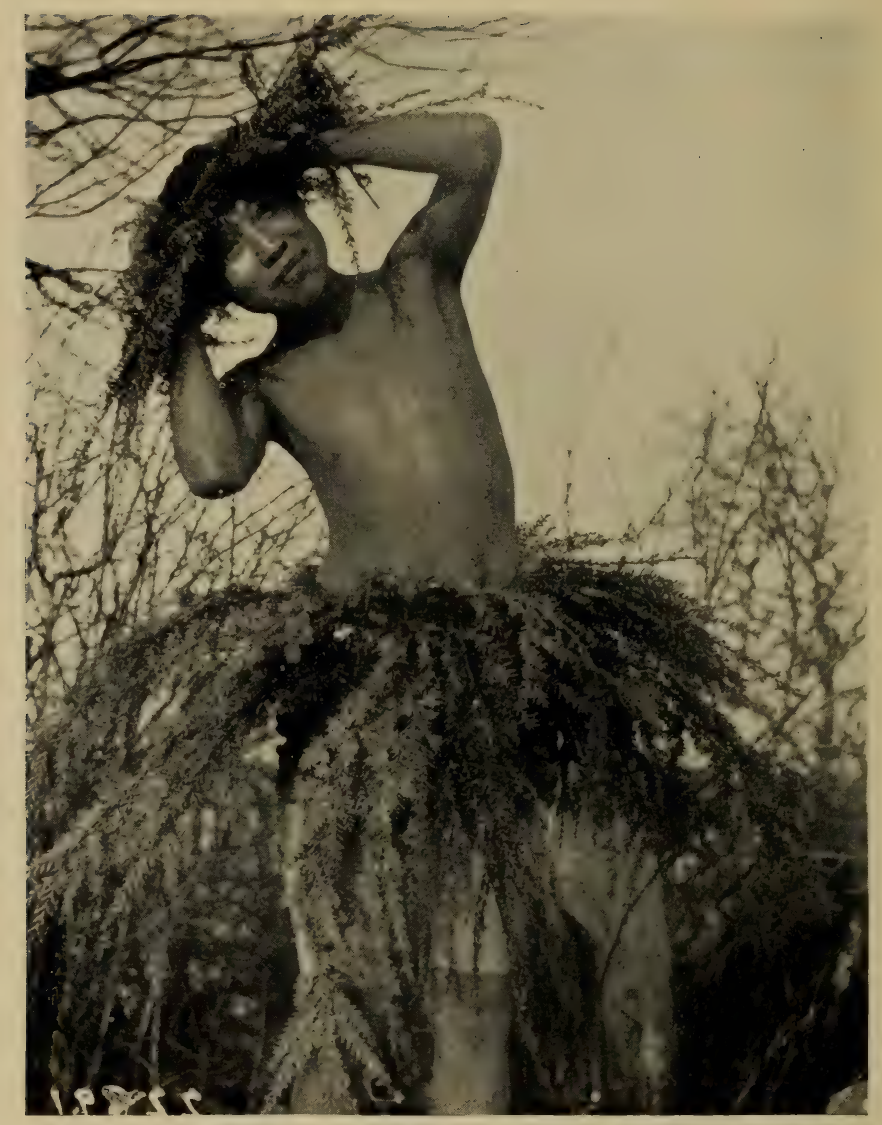

A Youth Showing the Hemlock Decoration of a Novitiate. Kwakiutl. 
or different personality. The various societies come to the house in groups and are assigned seats together. The seal society comes in last and is seated at the rear of the house with the cannibal society in the place of highest honor. The master of ceremonies circles the fire singing and swinging his rattle. The assembled people sing. each giving his own secret song.

Other men take the opportunity to have children initiated so that the ceremony is given as many times as there are novices, usually one for each tribe represented in the assembly.

There are feasts at night and during the next three days much singing and dancing. Meantime, the father-in-law turns over the promised property to his son-in-law, the father of the boy who is away with the supernatural ones being initiated by them. The third evening those who have been previously initiated are called to an assembling place in the woods where they are taught new songs by the singing masters who have composed them. The novice and his assistant, a kinswoman, are nearby in the woods listening, so that they will be able to dance to the songs when the ceremony is held.

Return of the Novice. The people of the village are formally called to the assembly house soon after dark. The messengers enter each house in the village and call the names of the inmates keeping the order of their society rank. When they have assembled, individuals come in one after the other and give one of the dances which they possess. Heralds are at the door who announce the dancers. There is much fun and goodnatured raillery. Occasionally messengers are sent out to listen if the novice is returning. Toward morning the ghost dancer appears and his song is sung. The older members of the hamatsa society suddenly enter the 


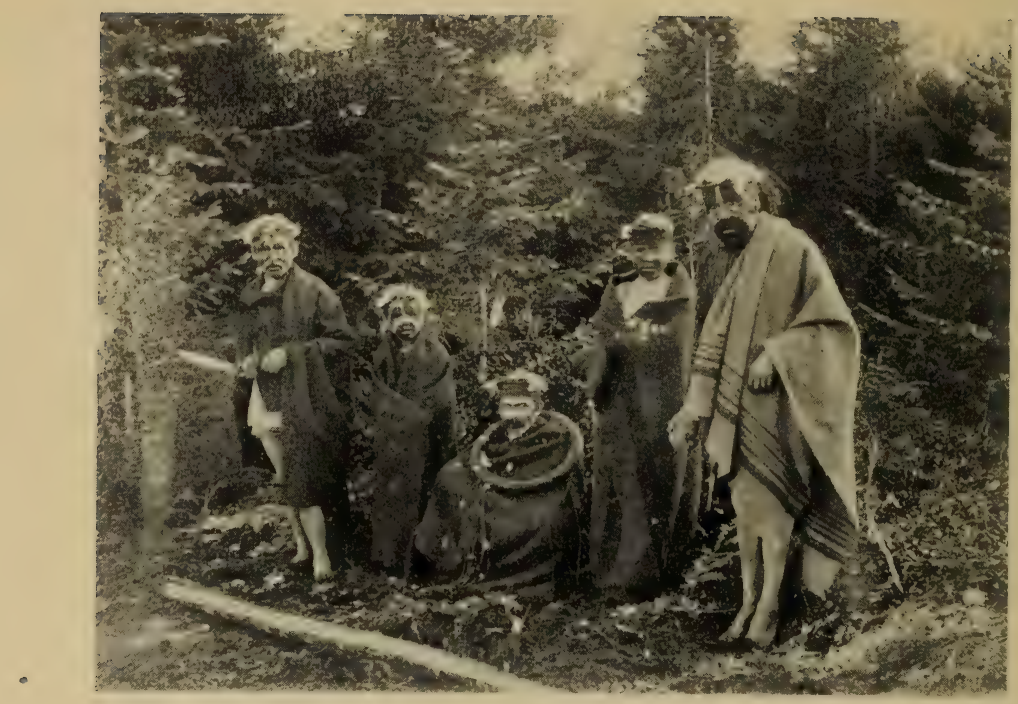

Fool Dancers of the Winter Ceremony. Kwakiutl.

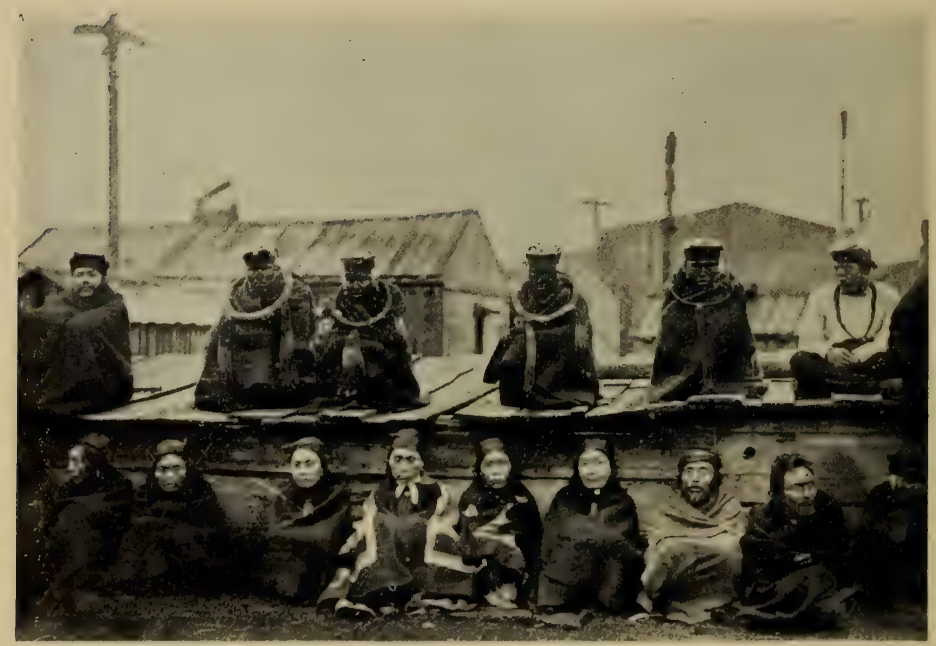

Cannibal Society of Winter Ceremony. Kwakiutl. 
house from both ends and through the roof above. They cry "Hap hap" and dance around the fire four times in a squatting position. The novice is supposed to hear their cries and to be attracted by them. He is heard on the roof, and after running around four times, he pushes a roof plank aside three times and the fourth time he jumps down. While some are trying to catch him he runs around the fire four times and disappears through a secret door in the rear of the house. He leaves behind the hemlock branches which were his clothing. He enters and disappears three times and then the assembly is dismissed.

After a short rest the people are assembled on the beach, where they take hands, forming a square, and try to surround the novice who appears, then disappears, to suddenly appear again at a distant and unexpected place. The fourth time he is caught through the device of putting in front of him a naked man; the novice rushes up to him and bites his arm. The kinswoman helper who has been in the woods with him during the four days now appears and dances into the house backward to lure the novice in. After much delay he enters and rushes about biting the arms of different people. He repeatedly flees to a room in the rear of the house which has been provided for him. After much singing and dancing he is restored to his senses.

Later, in private, a few of the leaders purify the newly initiated man and his female attendant. The property received from his father-in-law by the man giving the ceremony is publicly distributed. Payment has to be made to all persons bitten by the "cannibal." Incidentally, there are minor initiations and much supplementary feasting.

Ordinarily, there are initiations, similar to the one outlined above, given by other "tribes" resident in the 
village or temporarily there as guests. Each has its own ceremony, differing from the others in minor details. When given together there is much rivalry to see which group can give the most spectacular and mystifying performance.

Cannibalism. In theory, the cannibal novice while he has been absent has become accustomed to eating corpses. In the accounts of former ceremonies his woman attendant entices him into the assembly house by holding in front of him a corpse secured from the nearby village burial place. The candidate is said to have eaten the dried skin from the body and to have been joined in his feasting by the older members of the society. Often there would be contests to see which "tribe" had a cannibal society member that could outdo the others in corpse eating. There are also accounts of slaves being killed to supply fresh food for the cannibals. The biting and pretended eating of dogs caught up alive is the more common indication of frenzy shown by the northern tribes.

Magic Performances. During the ceremonies at night in the assembly house many wonders are performed. A common one is for a woman who has great supernatural power to invite someone to run her through with a spear, or to cut off her head. A shaman restores her and takes her underground in spite of all attempts to hold her. During one such exhibition a woman was struck by a paddle which seemed to cleave her shoulder well down to her breast. Blood was seen to flow in abundance. These are, of course, only sleightof-hand performances arranged in advance and executed with the aid of confederates. The head displayed as severed is a realistically carved one of wood. The blood which flows is enclosed in a bladder and is released by the blow. The spear supposed to be thrust 
through the body telescopes; and, by means of a string attached to the skin, it can be made to appear that the point of the spear raises the skin on the opposite side of the body. The corpse eating described above, no doubt, belongs also with these sleight-of-hand performances. Under the circumstances it is difficult to know how much of religious attitude and belief there is on the part of the initiated who plan and carry out the winter ceremonies. It is probable that they do believe that the candidate is in some degree possessed by the cannibal spirit and that those who appear in masks are temporarily acting as substitutes for the supernatural beings themselves. The deliberate deceptions are to impress the uninitiated by greatly exaggerating the display of supernatural power which may be sincerely believed to exist in less evident forms.

Supernatural Visitors. The chief religious significance may be the belief that during this period of the winter ceremony the invisible supernatural beings, at other times remote, are for the time being among men and in close social contact with them. This belief is clearly indicated for the Bella Coola who divide their year into two parts. During nine of their months the canoe of the salmon is in the Bella Coola country. As it departs, another canoe bringing the winter ceremony, arrives and remains four months. When it departs, the salmon canoe arrives again. The Bella Coola winter ceremony, in a general way, is similar to that of the Kwakiutl. It is believed by them to have been derived from their neighbors, the Bella Bella.

Haida Ceremonies. The Haida secret ceremonies are always combined with potlatches which are held when a new house and house posts are erected. Such affairs are only attempted when the salmon season is over, for then the people are assembled in the winter 
villages, have sufficient leisure, and food is plentiful for the feasts. The Haida myths place the supernatural houses where the original initiation took place under the sea. These locations are in the Tsimshian waters and, therefore, they claim that the ceremonies are Tsimshian in origin. There are several varieties of societies; fire throwers, dog eaters, etc., but in the main, the performances are similar to those described for the Kwakiutl. The mysterious whistles are used and called spirits; arms are bitten; the novice is killed and restored to life. The right to be initiated is inherited, or is bestowed by one who has inherited it. Sleight-of-hand and dramatic performances are also provided.

Tlingit. The Tlingit have such ceremonies only when a potlatch is held after the death of a prominent man, when his remains are entombed and the memorial is erected. The sept divisions of the opposite clan give the performances with much rivalry, often involving serious conflicts. Each sept owns a wand or standard which, if set up between groups about to fight, immediately inhibits the conflict.

\section{Potlatch.}

The word potlatch comes from the Chinook jargon and originally meant "to give." In its common use among the white people and the natives on the Northwest Coast it has taken on a very general meaning and is applied to any Indian festival at which there is feasting, or, in connection with which property is given away. Because of this loose and general meaning there necessarily exists a good deal of confusion as to what is meant by the term. From the Indians' viewpoint many different things are meant when he uses the Chinook word in speaking to white people, for it is the only word intel- 
ligible to them by means of which he can refer to a considerable number of ceremonies or festivals each having its own Indian name. When the white people employ the term they undoubtedly are thinking mainly of the disposal of property.

Although in the discussion of the various ceremonies the potlatch features have been described, it may be useful to attempt here a recapitulation of the main points. There are perhaps two main principles involved; first that all events of social or political interest must be publicly witnessed; and second that those who perform personal or social service must be publicly recompensed. There is a third more general social law that all guests on all occasions must be fed.

Potlatch Occasions. If we may judge from the more widely distributed aspects of the ceremonies of the various tribes along the coast, potlatching was primarily the accompaniment of certain crises in the life of an individual.

A child under a year old is referred to as having been born at such a place. When it is a year old a name is given it; and presents of a mat or paddle are made to the members of the sept. At ten or twelve a boy receives another name and there is a greater distribution of property. The girl at a somewhat more advanced age reaches maturity; and among the Nootka a very important feast with a lavish distribution of property takes place. At a less definite age the boy is initiated into the secret society to which he has an inherited or an acquired claim. This is also an event of great importance among the southern tribes. As has been described above, betrothal and marriage are also potlatching oceasions. Of still greater importance is the ceremony at which the feather-in-law makes return gifts, which usually takes place some years after the marriage. 
Among the northern tribes, Haida, Tlingit, and Tsimshian, the main potlatch occasion is when after the death of an important person the final burial rites are held, the remains are entombed, and a memorial to the dead is erected. The burial duties devolve upon the family of the father of the deceased, connected of course with the opposite, or at least a different clan. At the time of the ceremony those who attended to the burial are recompensed. At this time, moreover, there are exhibitions of dancing by the other members of the same clan and a distribution of property to them also.

The building of a house requires the hiring of various individuals who secure the timbers and assist in putting them in place and in the ornamentation of the house with carvings and paintings. Often when potlatching is mentioned the winter ceremonies are meant. They are the occasions of the initiations into the secret societies mentioned above. It is probable also that the selling of a copper and the giving of an oil feast would be referred to as a potlatch.

One prominent feature of all the events enumerated above is the assumption by the giver of the feast of a new name. This always means an advance in standing and rank and is perhaps the strongest motive lying behind the whole system of potlatching.

Wealth Necessary. Since all these occasions require the dispensing of hospitality, considerable supplies of food are necessary. These can be accumulated by unusual activities in fishing and food gathering on the part of the man and his family, or in recent years by the purchase of provisions from stores with money received from wages. The second requisite is a supply of presents for distribution. These formerly consisted of slaves, canoes, and clothing, especially skins. Recently, the gray Hudson Bay blankets have superseded nearly all 
the other forms of property. These blankets can, of course, also be accumulated through purchase from the stores as a result of thrift. Such blankets when given away are not ordinarily used for wearing purposes, but are hoarded as a sort of currency. The giving of a potlatch is not merely a personal matter although an individual is the principle figure in it. His family and relatives are also interested and are bound by tradition to assist in making it a success. They are drawn upon for blankets which may be returned to them later.

Distribution of Wealth. When property is publicly given out it falls into two categories. A certain part of the distribution is in payment for services rendered, or as compensation for injuries. This is a limited transaction and the obligation is cancelled. The greater amount of property is given to invited guests, to each according to his rank. Such gifts cannot be declined, and become binding obligations upon the recipient and his heirs, so that when he in turn gives a potlatch, he must give more than an equivalent to this man, or his heirs. In this second case, giving is really profitable loaning. Among the Kwakiutl such forced loaning is not confined to public occasions. If a man is planning to give a potlatch, he loans out his stock of blankets some months before the erent and collects them again with considerable interest.

Purpose of Potlatch. The main purpose of the potlatch may be assumed to be the impression made on the public mind. It is this which elevates the man and his family in the public estimation. The more widely the invitations are sent out, the more spectacular the display of property, and the more lavish the feasting, the greater and deeper is the emotional result and the longer it will endure. To increase this effect the property is publicly displayed on the beach and spread out. Is a 
permanent record, posts are erected at either end of the long piles of blankets. Often too, in recent years, inscriptions are placed over the man's door and added to his grave monument so that the event will not be forgotten.

\section{The Future World.}

The most characteristic belief in regard to the fate of souls after death is that it depends upon the kind of death by which they are freed.

The larger number, those who die of old age or disease, go toward the west and have to cross water barriers, usually rivers. There is some disagreement whether the world of dead is on the same level as this or below it. Life in that world is similar to this, but much less agreeable. To some degree the souls are dependent on their surviving relatives for food and clothing. The latter is chiefly supplied at the time of the funeral, but food is sent frequently by placing it in the fire. Singing after a death is an advantage to the traveling soul for it illuminates the trail, and, according to the Haida, permits the soul to enter its new abode with its head up. Those who die by drowning go to the underwater deities, the killerwhales. Offerings for them are put in fires near the seashore or thrown into the ocean. The souls of those killed in warfare go to a world above, by no means a paradise, but a fairly endurable place. Those who die unavenged have difficulty in climbing up.

Shaman's souls also go to a special place - according to the Haida, an island. Certain of the shaman's powers continue an association with the body which, it will be remembered, is given a different sort of burial from that accorded an ordinary person.

A second death is believed to be possible so that the soul passes from the first place of the dead to another, either below the first or farther to the west. Some of the 
souls, perhaps the majority, are reborn usually in the same family to which they belonged in the first instance.

The Bella Coola believe that at death three separate entities survive. One of these goes above to the House of Myths, a second goes to the world of the dead, the next below this one, and a third part manifests itself here in the hooting of the owl.

\section{Mythology and Folklore.}

The myths of a people are generally assumed to be a formulation of their belief in the supernatural origins of the world, and of mankind and his social institutions. In so far as they treat of the supernatural they may be viewed as religious in character. But besides giving an account of the creation of the world, of a flood, and other events of moment, there are usually found many narratives and incidents, trivial and ludicrous in character. To a certain extent the constitution of the universe does justify a degree of levity and humor in a full treatment of it, but many of these myths go far beyond a proportionate reflection of the cosmic incongruities. It is evident that the creative imagination of mankind has been at work and the gods and heroes are made to furnish amusement by their adventures and pranks. We are dealing then, in a large measure, with literature rather than with religion. In North America there are several of these godlike-clownlike characters. In the east we have Glooscap, and Manabus; in the Plains region "Old Man," greatly given to tricks; and in California, Coyote who secures the sun and fire for man and regulates all sort of matters, but who at other times displays the stupidity and baseness of his combined animal and human personalities.

Raven Myths. The chief character on the North Pacific Coast is Raven. The perople live close to the 
shore and ravens are always about, the most intimate and sociable of man's animal neighbors. It is noticeable that there is an attempt to sublimate the raven's personal characteristics by representing the mythical hero as simply wearing at times a raven's robe and assuming his form as a disguise. The Tlingit distinguish the hero as the Raven of the head of Nass River; a being distinct from the common bird. There can be no doubt, however, that the real bird has contributed much to the conception of the hero's personality and has suggested many of the grotesque incidents. This is particularly apparent in many episodes in which his voracious appetite is the main motive.

In the beginning, according to the Haida, Tlingit, and Tsimshian myths, the sea covered all the world except a flat rock on which $t$, supernatural ones lay crisscross. Raven alighted a ng these beings and then flew to the top of the sk. rough which he was able to pass. Having arrived in $t$. upper world he displaced the chief's infant grandson. Soon after, he was dropped while in his cradle and fell into the sea. A messenger invited him to a house under the water where he was given two cylindrical objects and directions for using them to make land. He bungled the matter somewhat, but the objects given him expanded to form first the Queen Charlotte Islands and then the mainland.

Among other adventures, Raven was befriended by Beavers who had a lake filled with fish and a salmon trap for catching them. Raven taking advantage of the absence of his hosts, rolled up the lake, fish, and fishtrap and carried them away in his armpit. By this means people secured the use of fish as food. After this, Raven fell in with Eagle and by trickery got away from him a basket of fresh water. As Eagle chased him, Raven spilled the water here and there making the fresh 
water lakes and streams, also necessary that there might be fish for food. Later he got olachen from the supernatural owner and keeper of them by pretending that his canoe was already smeared with olachen grease and spawn, and distributed them at the various places where the fish are plentiful. By changing himself into a conifer needle and floating on the drinking water he procured his birth as a child of the chief's daughter. He cried perpetually for daylight kept in a box by the chief until his grandfather ordered that it be given him to quiet him. Resuming his bird shape he flew through the smokehole with the box and later placed the stars, moon, and sun in the sky. He secured fire by appearing among the animals at the house of the guardian of fire in the form of a deer. He tied faggots to his tail and, when the opportunity ' Cered, set these on fire and ran out. By switching his tail against the trees he made them capable of suppor ing fire.

He tried to make an old woman who held the tide line believe he had already gathered sea urchins. He blinded her and made her promise to let the tides run out twice a day instead of at much longer intervals. This made the digging of clams and gathering of low-tide food possible.

At one time also he caused the waters to rise, making a flood, escaping himself by means of an arrow chain. He shot the first arrow into the sky and each succeeding one into the nock of the preceding one until he was able to climb up to the sky.

He gave the birds their various colors by painting them. His own blackness is due to his being caught in the smokehole of a house and being subjected to prolonged smoking.

Besides the beneficent deeds mentioned above, there are a great number of other exploits some of which seem 
intended to show what might be done with unlimited magical power. There are also many which are rather coarse, in which Raven satisfies his appetite for food or sexual gratification, making use of all sorts of tricks in order to accomplish his ends.

Family Traditions. Besides the myths commonly known to the entire community which treat of matters of general public concern, there are many myths and traditions connected with particular families and considered to be their private property. Many of these secured from the Kwakiutl have been published. They are intended to account for the high standing of the family, and its right to the use of houses, house furniture, certain personal names, and various ceremonial possessions. The narrative may be the bare outline of the movements of the early ancestors. The first one, a whale, travels in his whale canoe until he comes to a desirable place, where he disembarks and builds a house with certain peculiarities and having a certain name. The ancestor continues his journey, marrying the daughters of many chiefs and constantly obtaining new names and rights which become hereditary. The fortunes of the family are traced down to the present and justifies their claim to recognition. Another type of Kwakiutl story usually concerns a young man of early times who after many purifications comes to a house into which he is invited. The door is alive and opens and shuts. The house posts are also alive and talk, or in the house is a woman grown to the floor. Sometimes as a result of marriage, but at times without, the young man is given the house with its contents, the personal names of the owner, and his ceremonial masks, songs, and dances.

As an example of one of these myths which explains the history and possessions of a group, the following. 
abstract may be of interest. It concerns the Kwakiutl sept, Wiwomasgem.

A Thunder-bird named Too-large suggested to his wife that they go down to the world beneath them. They did so and came to the mouth of a river where a man named Only-one-on-the-beach was building a house unassisted. The Thunder-bird and his wife took off their masks, appeared in human form and took the names Head-winter-dancer and Head-winter-dancewoman. When Only-one-on-the-beach's house was finished, he assisted the visitors in the building of their house on a hill by a river. Here in a short time four sons were born to the couple. These boys grew up with magical rapidity and were established in houses of their own at some distance from each other. For the fourth son, Head-winter-dancer called down his own house from the upper world and presented it to his son with a number of masks and the names and dances belonging with them.

Head-winter-dancer had made himself a salmon weir with a trap to hold the salmon. One morning he found a mysterious salmon in the trap which after some treatment took its proper form of the two-headed serpent. Just at this time a fifth son was born. When the baby was washed, blood from the serpent was put on it and the parts so treated became stone until the boy, now twice the size of an ordinary man, was all stone, on the surface at least, except for his neck. His mother then recognized him as the offspring of Dzonoqwa, a supernatural being who had visited her during a fainting fit. The boy destined to be a warrior was named Stonebody.

This man, of double stature and largely composed of stone, could not travel in an ordinary canoe. His father then remembered that a self-propelling canoe 
named Paddleside-serpent-canoe had been promised him by Only-one-on-the-beach in payment for curing his sons of frogs which had infested their stomachs. This proved to be the proper means of transportation for Stone-body. First he was taken to the houses of his four brothers and introduced to them by his father. After that he set out to make war on the whole world to secure slaves, wealth, names, and dances for his brothers. The canoe transported him and his slaves at a word of command.

When he appeared in the offing before a village his shout killed or rendered insensible the men, except the chief of the village, who immediately bought off Stonebody with slaves, skins of animals, and names with their prerogatives. These Stone-body transferred to his brothers. Finally Stone-body went south to Comox, a Salish settlement near Cape Mudge. Here he secured the ceremony of the earthquake (Xwexwe). After his return, he went up a certain river, very dangerous because of its water monsters, to secure eagle down. At a certain place, he was attacked by two brothers of his elder brother's wife, sons of one of Stone-body's victims. They succeeded in destroying the Paddlesideserpent-canoe and in killing the crew and Stone-body himself. They had been told he was vulnerable in his neck, the only part not turned to stone. The heads taken as trophies were carried to the village of two brothers where they were discovered by their sister on one of her visits to her former home. When Stonebody's relatives came for revenge, they were all killed by the two brothers who had great supernatural power.

This story, many of the details having been omitted here, explains various names of the important people in this Kwakiutl sept, why they have houses with certain carved posts, and the ownership of the salmon rivers, 
and how they came to have the right to certain masks and dances. Several of the masks and other ceremonial objects in the Kwakiutl collection of the Museum are those mentioned in this narrative.

Taken altogether, there is a large and varied body of oral literature possessing very much local color and showing much growth and modification at the hands of the Northwest Coast peoples. Many of the basic conceptions, as well as a great number of definite incidents are, however, to be found among distant tribes. The Raven myths are known on the Asiatic coast as well as north and south in America. As in all other phases of culture, the myths and tales of the Northwest Coast tribes are strongly stamped with their peculiarities. 


\section{Chapter V.}

\section{ART.}

Textile Decoration. Since art exists mainly as the embellishment of objects of utility, its development in any one region is largely dependent upon the general industries practised there. On the Northwest Coast pottery is entirely lacking and clay, the material most readily modeled, is not employed in art. The household vessels are mostly made of wood; wood carving, there-

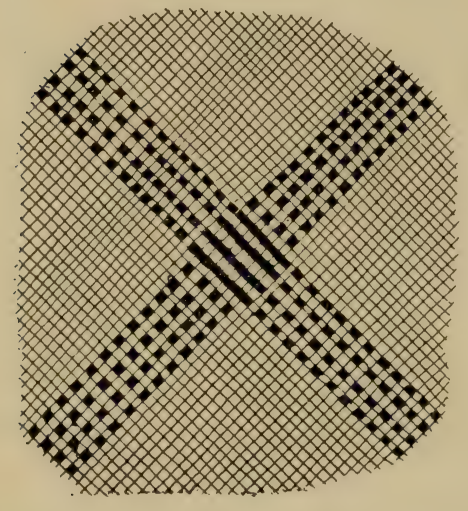

Checker Design on a Mat. Kwakiutl.

fore, is the most prominent art manifestation. In the south, among the Salish, and in the north, among the Tlingit, basketry is well developed, but in the main middle portion of the area, except for hats, the baskets made are chiefly crude and used for gathering and carrying clams and similar work for which decorated basketry is unsuitable. Mats, however, are common to the entire area, as has been said above. On them we find the simple, mathematical, decorative art to be expected in textiles, wherein the elements employed cross at right angles to each other. There are stripes of brown or black; solid or with alternating stitches of background and color. Squares and rectangles are also employed. The blankets of the Salish and some very old examples from the north have similar decorations. Also in the north there was formerly porcupine quill embroidery which 
quite naturally lends itself to the same sort of geometrical ornamentation.

We find then on the Pacific Coast, as one kind of art there, the same type which is common to the rest of North America. Nearly everywhere textiles are made by women, and as a result the decoration of them has been produced by women and is their art. Examples are seen in basketry in Califor-

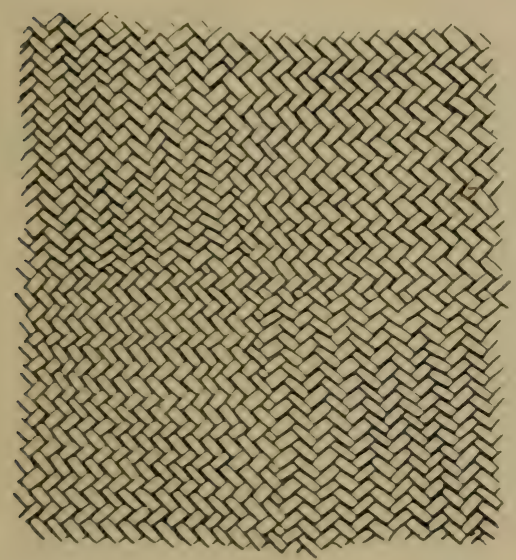

Deroration Produced by Varying Direction of Elements in Twilling. Kwakiutl. nia and the Southwest and in the porcupine and bead embroidery of the Plains. Wherever pottery exists north of Mexico, it is also the work of the women and textile designs are often transferred to it. On the Northwest Coast where there is no pottery and where clothing is scanty women's art contribution is rather limited.

Carving. The men, on the other hand, make the canoes, erect the houses, manufacture the implements employed in fishing and hunting, and provide the wooden dishes for household use. Man's art inclines more toward realism, for one reason, a negative one, because the necessities of textiles have not constrained him. His art on the Northwest Coast takes the form of carving in the round and in relief, and of painting. The materials used for carving are wood, bone, horn, and, more recently, slate. As has 
been mentioned above, he has been fortunate in the character of the wood available for his work. The cedars are soft, straight, and fine grained. Also the large alders supply wood very suitable for carving with primitive implements.

Woman's art, being decorative and representative, deals with contrasts of light and shade, with lines and masses, and is always guided, in part at least, by esthetic motives. The representative carvings and paintings of
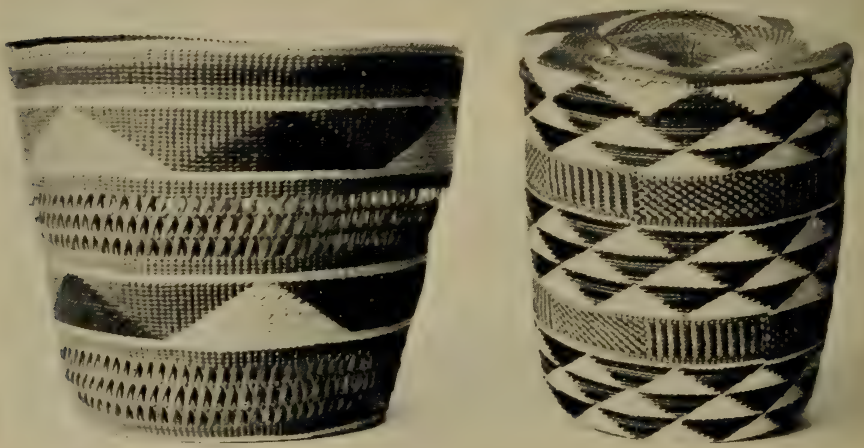

Baskets Illustrating Geometrical Designs. Tlingit.

the men, however, may not depend at all upon esthetic principles for their result. The emotions aroused in the beholders may be stirred by suggestion, through memory associations. Ordinarily, the more realistic the art object is, the stronger the emotional result. This would certainly be true of the rendering of a grizzly bear which might be so realistic as to produce fear. That the better carvers of the Northwest Coast are skillful enough to make accurate realistic representation, no one need doubt. Some of the grave monuments are executed in 


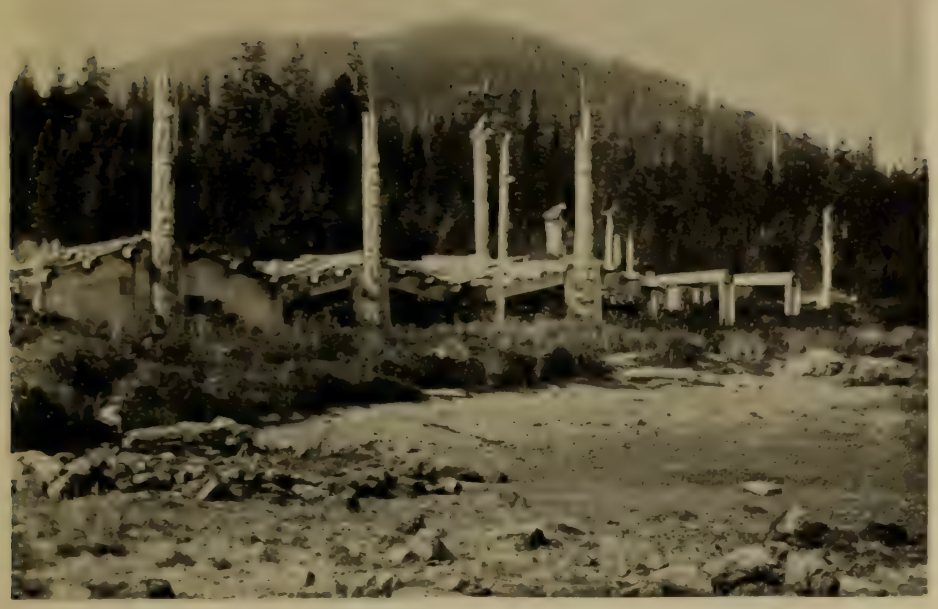

Haida Village of Tanu, Queen Charlotte Islands. Photo. by Dr. C. F. Newcombe.

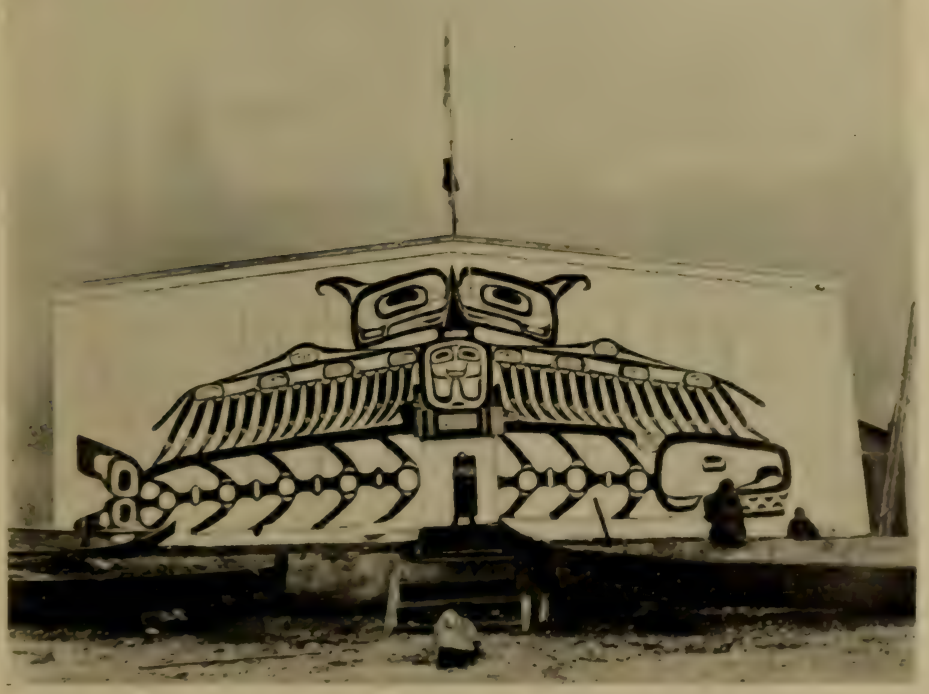

Painted House Front: Thunderhird C'arrying off a Whale. 'Alert. Bay. Kwakiutl. 
that spirit. There are also Tlingit masks which are, without doubt, portraits.

There are two reasons why realistic art is not common on the Pacific Coast. In a great many cases where the object carved is for a ceremonial use the animals represented are not the familiar ones of everyday life. They are either mythical beings belonging to the super-

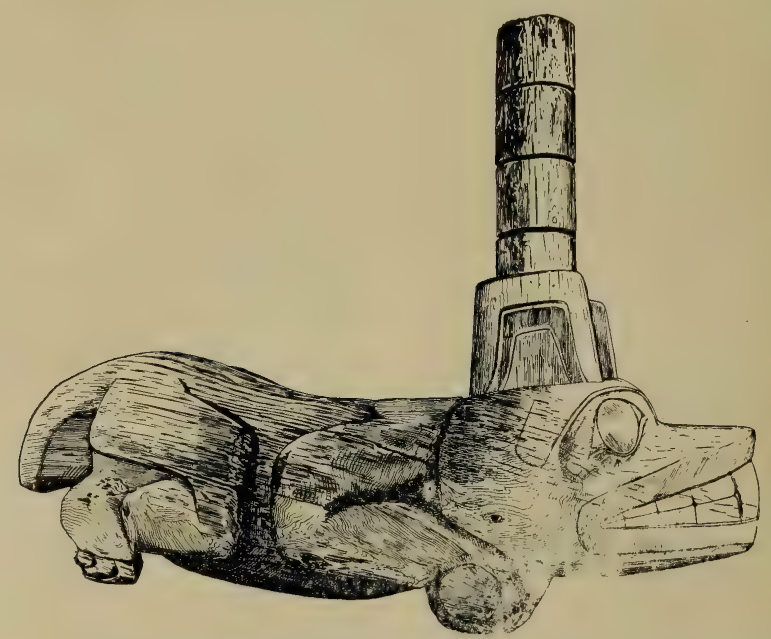

Support of a Grave Box to Represent a Beaver Wearing a Hat. Haida.

natural past or present, or they are the actual animals represented in their more nearly human form, which they are all thought to possess. In the second place, the totem poles in particular are intended to suggest a narrative or a combination of ideas. To do this the artist takes liberties with the sizes and relations of the animals in order to bring about the combination he desires.

Grotesque Art. It is the first motive mentioned above that is responsible for much of the grotesqueness 
of the art of the Northwest Coast. The Kwakiutl represent a mysterious "woman" of the woods and try to produce in her likeness the mystery and fear which the
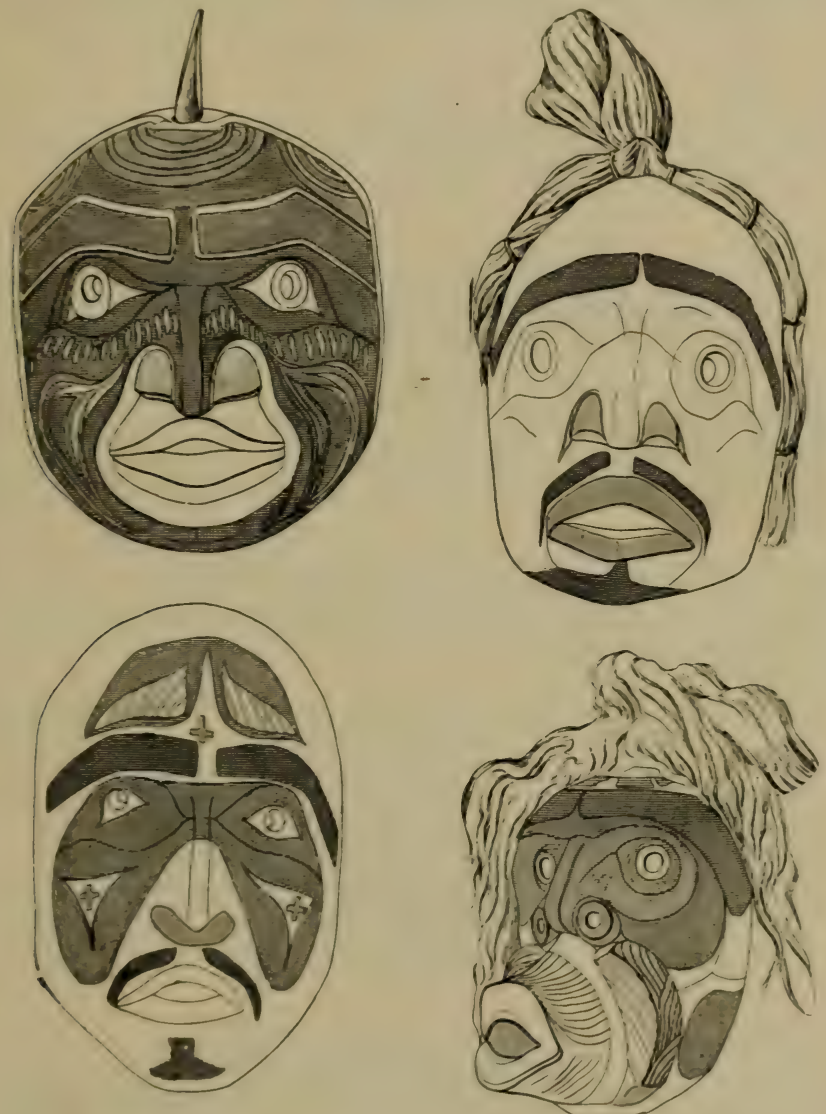

Masks Representing Supernatural Beings. Bella Coola.

belief in her inspires. The manymasks used in the ceremonies are intended to and do produce, especially in the children, feelings of horror and dread. The 
object of the ceremonies is to magnify the power of the initiated who are believed either to be aided by the monsters represented, or are to be able to withstand and control them. The double-headed snake is one of

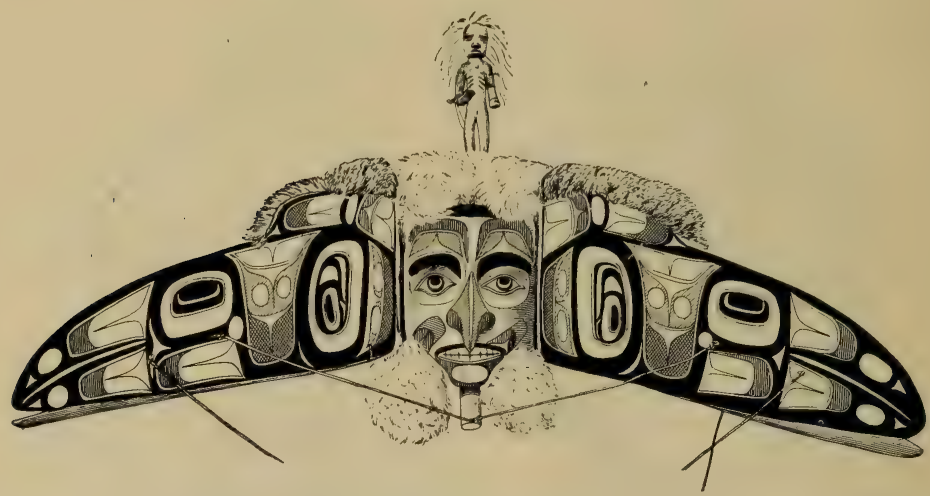

Double Mask: Closed, Raven as a Bird; Open, Raven as a Man. Haida.

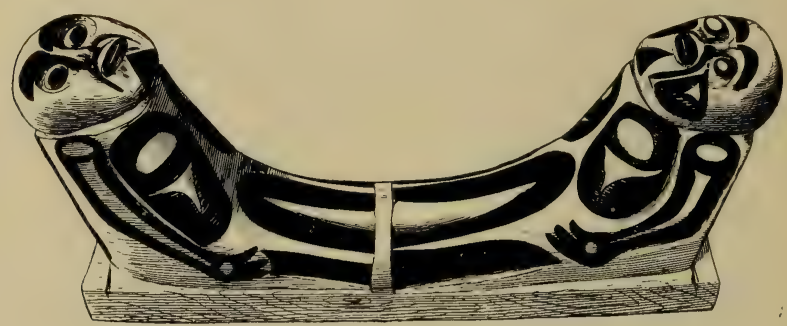

Harpoon Rest for Bow of Canoe. Kwakiutl.

the most powerful of the supernatural helpers of the Kwakiutl. The conception of its power is increased by making it a monster and giving it two heads. In general, the northwestern conception of supernatural power combines a considerable degree of horror and 


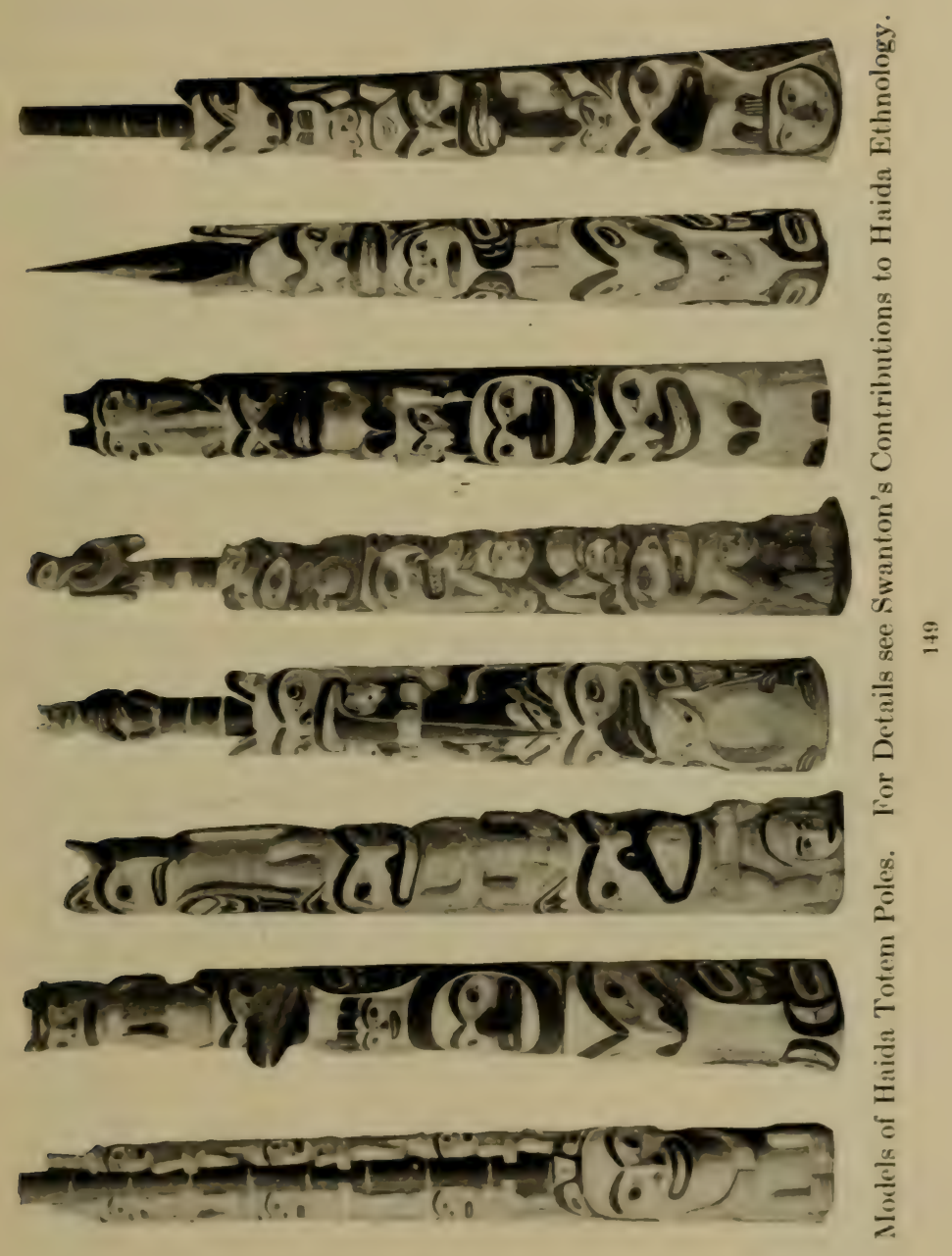


fear. A good example is the cannibal spirit represented as feeding on human corpses. The conception is no less repellent to Indians than to us, except that repetition and familiarity in time breaks down the reaction.
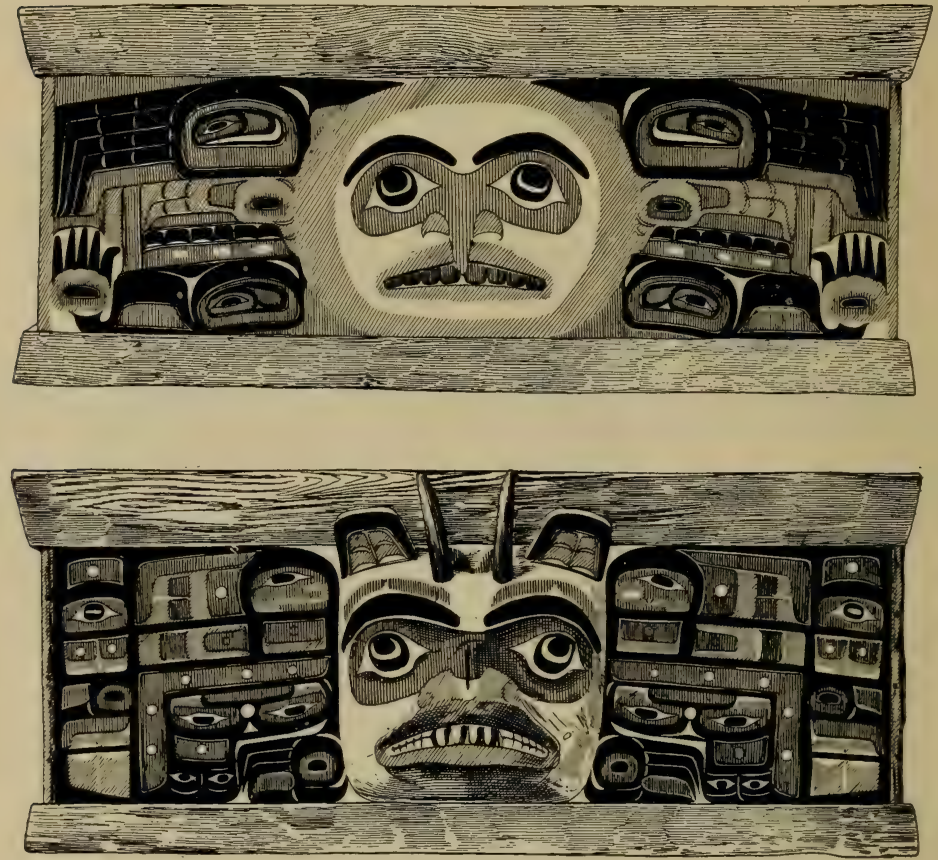

Front and Back of a Box: Moon as a Bird (above); Mountain Goat (below).

Totem Poles. Examples of connected narratives in Northwest Coast carvings are not very numerous, but they do occur on totem poles where some incident in an origin myth is sufficiently given to recall it unmistakably. More generally it is desired to represent the main crests belonging to the family. These may be 


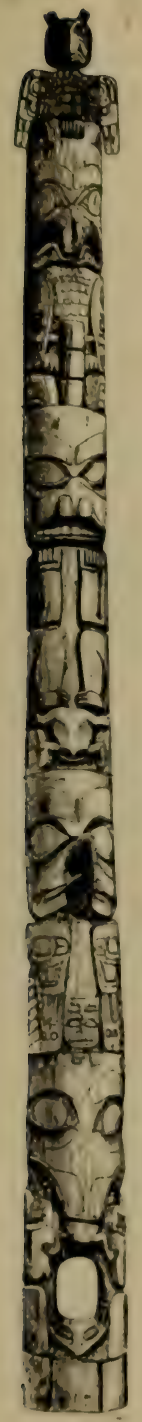

Totem Pole in the Museum. Haids. two, three, or four, belonging to the man and his wife, and occupy prominent positions at the top, bottom, and middle of the pole. They are joined and the remaining space occupied by the representation of stock objects such as frogs, etc. Upon these poles it is often desired to represent animals as the ancestors of the family and they are, therefore, shown with human faces and-are distinguished from each other with difficulty.

Conventionalizations. Carvings of this type approach picture writing and tend toward hieroglyphics, perhaps with an intention of not making the story too apparent.

Certain features of animals have been selected as symbols and with these in mind as keys the figures may usually be identified. Animals are distinguished from men by erect ears placed above the eyes surmounting the head. Of the animals, birds are to be recognized by their beaks, imposed often on an otherwise human face. Fish are indicated

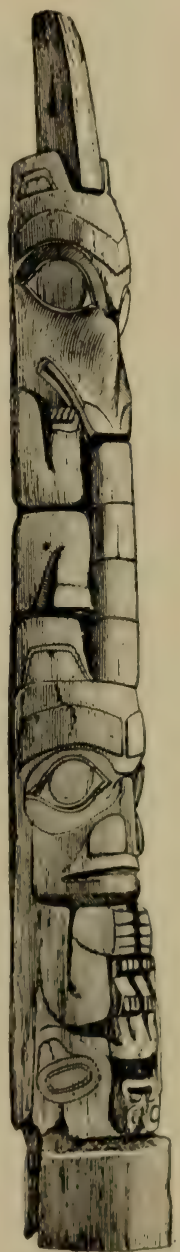

Memorial Column in the Museum. Haida. 
either by gills or fins. The three most common birds, raven, eagle, and hawk, may be distinguished by the shape of the beak; straight for the raven, curved for the eagle, and curved until the tip

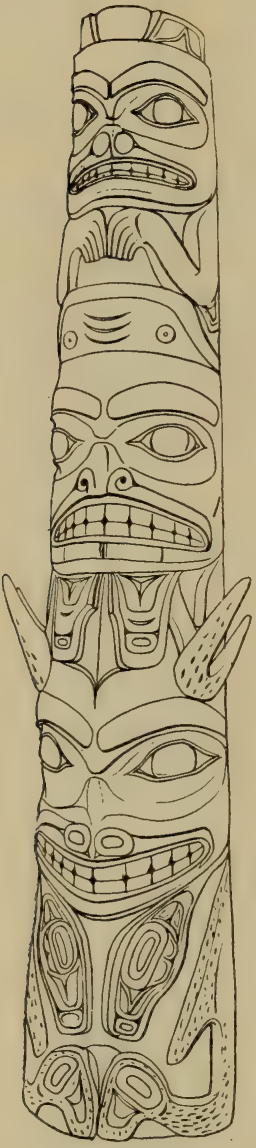

Totem Pole: from below upward; Sculpin, Dogfish, Sea Monster. Haida. rests on the mouth or chin for the hawk. Of the land mammals, the beaver is represented in full by large incisor teeth, a scaly flat tail, and a stick held to his mouth with his forepaws. The grizzly bear is indicated by a large mouth full of teeth, a protruding tongue, and large paws. The killerwhale, found many times and under a great variety of conditions, is symbolized by the dorsal fin and generally also by a blow hole. Of the fishes the shark can be recognized by a vaulted forehead on which are three crescents. The sculpin, in addition to gills, has two spines over its mouth.

Besides these natural animals, often shown in a human or supernatural phase, there are supernatural beings, or personified natural objects. The moon, for instance, is often shown with a circular face which resembles a hawk. The mythical thunderbird does not differ much from an eagle. If the bird is bearing off a whale, the first is certainly intended. A water monster may appear in a variety of forms and be mistaken for a bear or a beaver.

It appears that heraldic and mythological art can have its full effect 

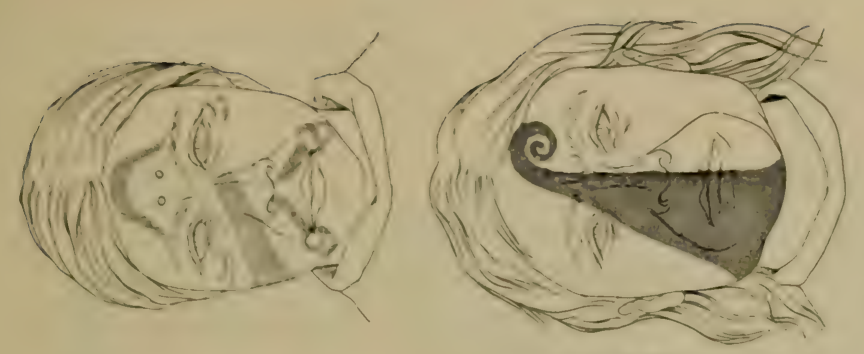

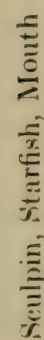
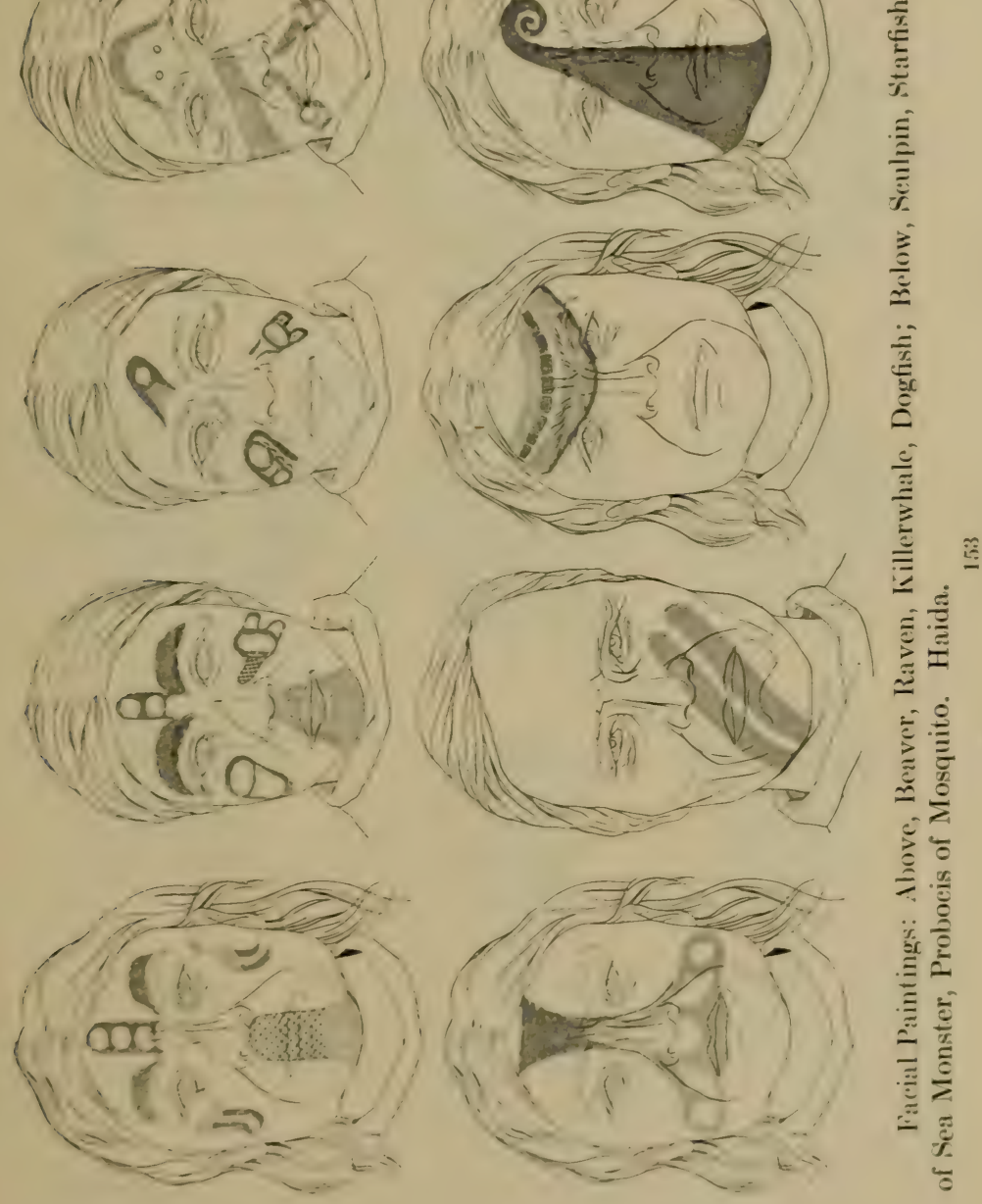

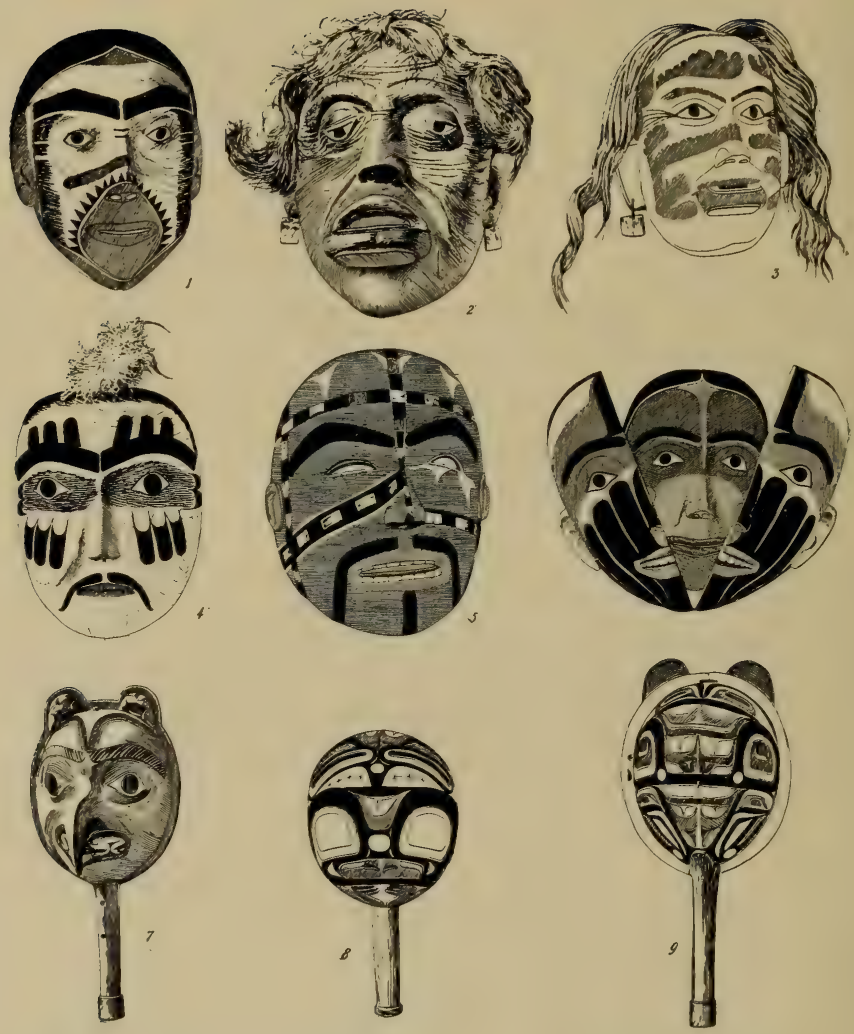

Masks and Rattles. Woman with Labret is Represented in 2. Haida. 
only when those who view it are entirely familiar with the stories and conceptions which lie behind it. Since in many cases these myths of family origin are not fully known except to the members of the family, they alone are capable of receiving their full emotional value. To some extent then the art is esoteric.

Carved Ornamentation. We may consider that the primary object of house posts, totem poles, and memorial

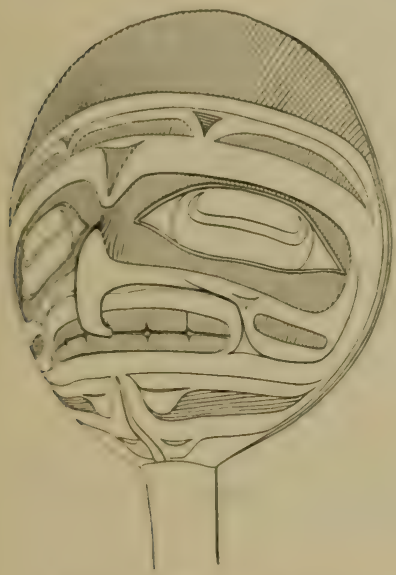

Rattle: Design a Hawk. Tlingit.

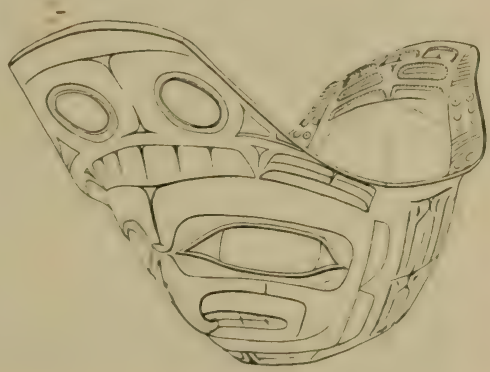

Dish of Mountain Sheep Horn Representing a Hawk. Tlingit.

columns is to present a graphic representation of varying and related concepts. If now we consider other objects such as dishes, spoons, clubs, etc., the carving becomes secondary and must supplement the article's use. Feast dishes possess names and are conceived as animate. They are carved in the form of men or animals with a bowl in the back or belly according to the posture chosen. Simaller oil dishes are often made to represent a seal, in which case a fairly realistic head or face is 
carved at one end and a tail at the other. On the two sides the flippers are also sometimes represented. The natural proportions of the animal, however, give way to the requirements of its use as a vessel. Bowls of mountain goat's horn are given very effective representative appearances by means of low relief carving. The handles of spoons are somewhat more difficult because of their tapering shape; but when once the habit of decorating has been established, and the principle of representation by parts has been adopted, many obstacles can be successfully overcome. It is generally conceded that

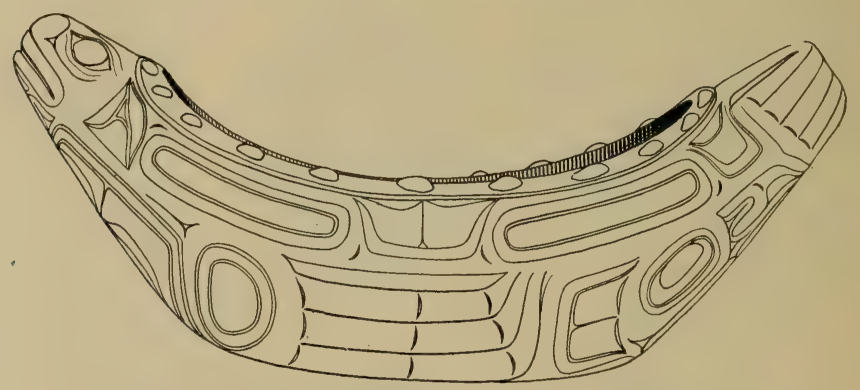

Grease Dish in Shape of a Seal. Tlingit.

the Northwest Coast peoples did not smoke tobacco until Europeans introduced the habit about 125 years ago. The Tlingit and Haida have within that time carried over the carving habit from the making of spoons and rattles to pipe-making, and have produced a marvelous variety of forms.

Rearrangements and Dissections. So far, man's art has been illustrated and discussed from his work in the round, or in carving in high relief. The square boxes made by folding a single straight board, as described above, also offer opportunities for decoration, but in low relief and usually with color added. As in the case of 
the dishes dug out of a single piece, it is feasible to carve on one end the front aspect of the animal, on the opposite end his rear parts, and on the sides, the sides of the animal's body. Still greater freedom is taken in this case with the relative size and relations of the body parts. The liberties taken in these respects seem to have moved along these lines of altered proportions and of an

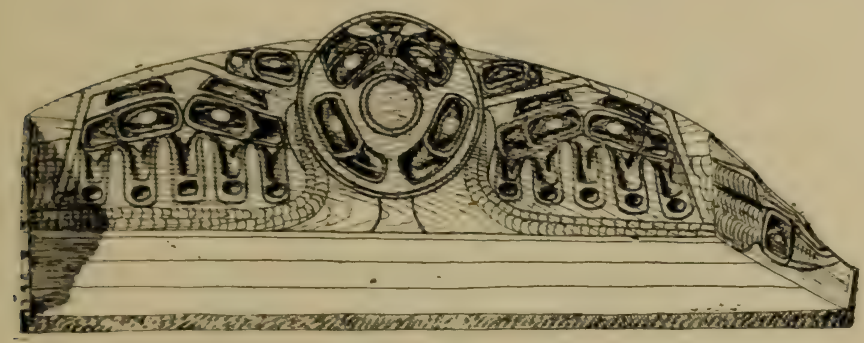

Settee with Family Emblems Carved on the Back. Kwakiutl.
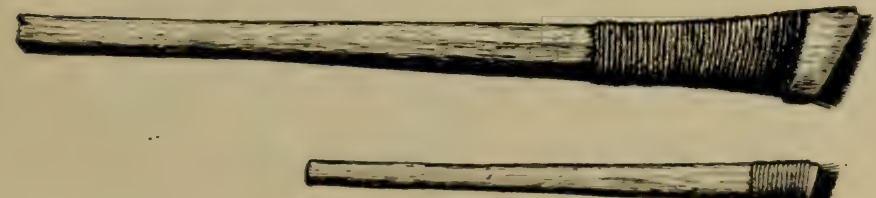

Paint Brushes. Kwakiutl.

analysis of anatomical parts amounting to actual dissection. Frequently an animal is shown as if it were split from the rear to the nose and spread out into two profiles joined in front only. Examples are seen in bracelets where the two parts of the longitudinally bisected animal encircles the wrist. Paintings on a plane surface are also treated in this manner, where no evident obstacle has been the compelling cause. In the 
bear split down the back and spread open as a painted decoration on a Tsimshian house front, it seems probable that the bilateral natural symmetry of the animal has been utilized by the artist to give a symmetrical treatment around the house entrance through the bear's navel.

Symmetry. We have been dealing with neither realistic,lnor plain symbolic art, but with a representative

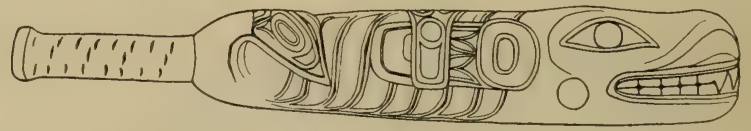

Club Representing a Killerwhale with Dorsal Fin Bent down. Tlingit.

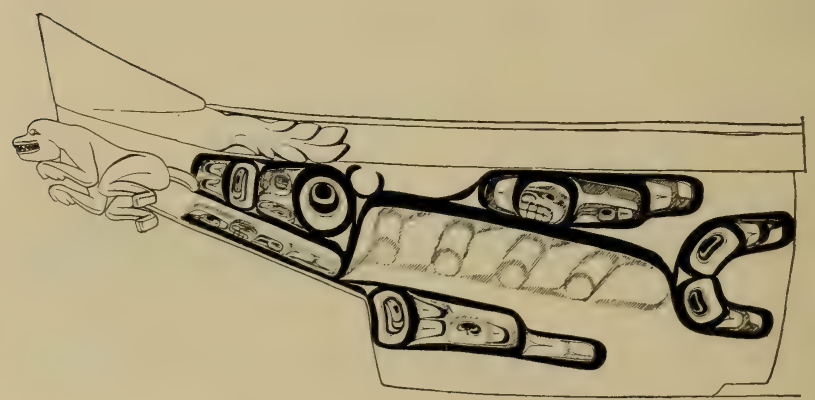

Bow of the Large Canoe in the Museum: Painting, a Killerwhale; Carving, Wolf.

art which relies for its effectiveness chiefly upon associative memory, as is the case with spoken or written words. In the preceding paragraph we came to an arrangement where the esthetic principles of composition and symmetry intrude. On this side there opens up a field of men's art where the medium is low relief carving and painting in which the elements of design employed are 


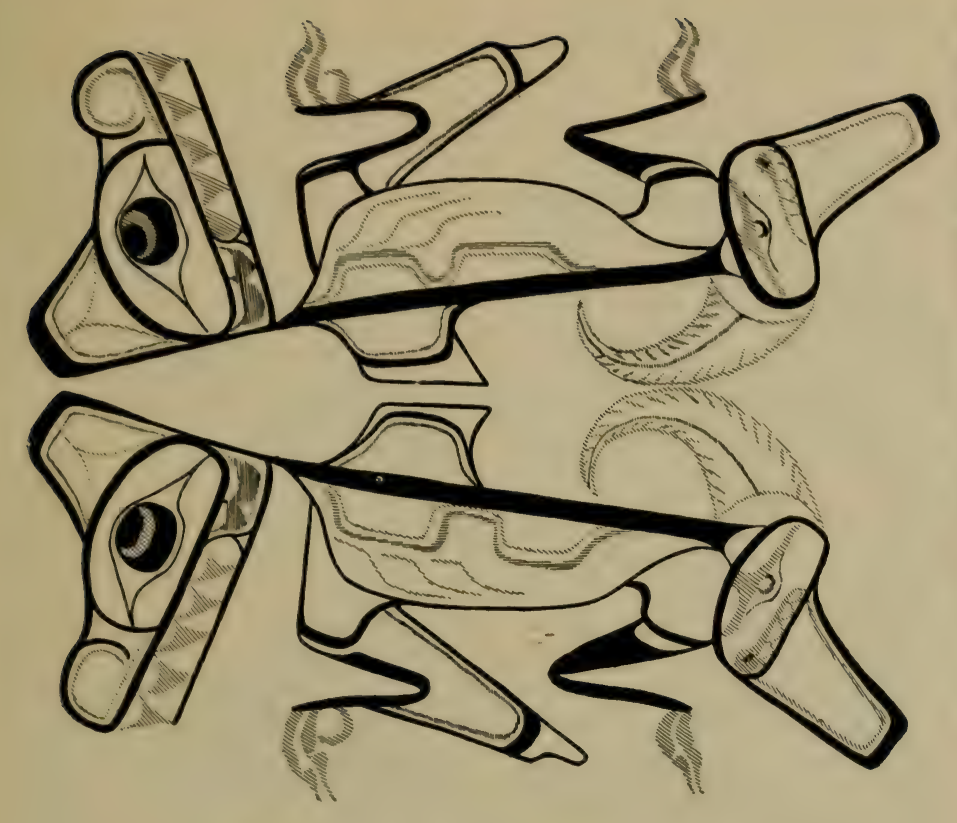

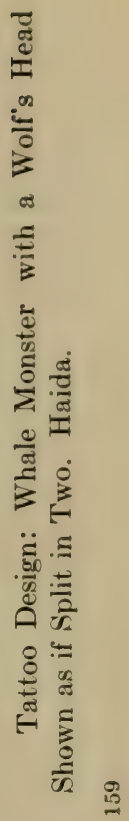

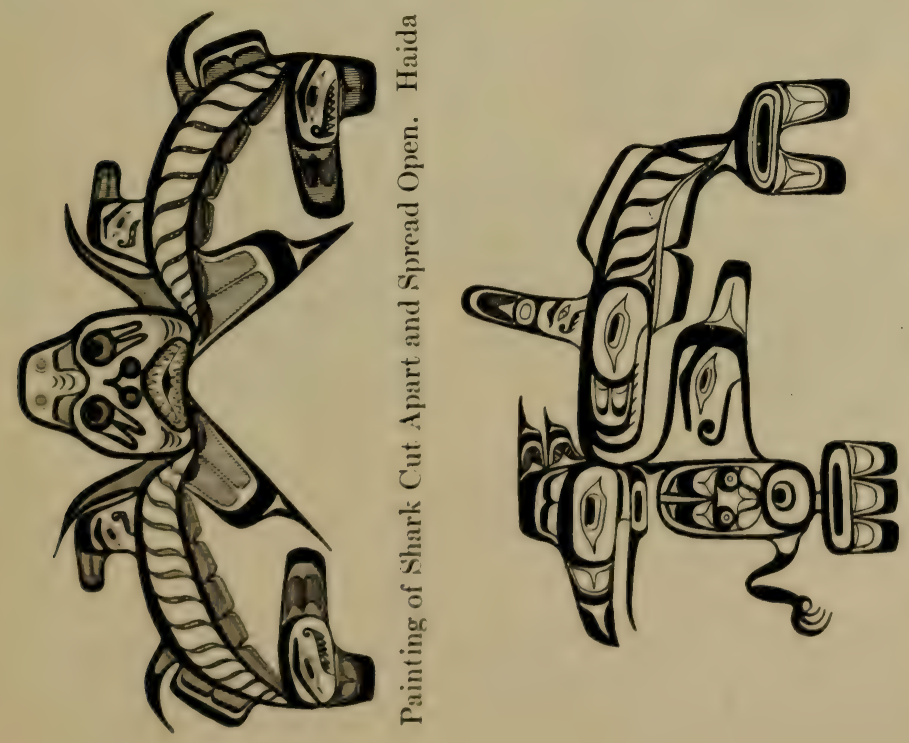

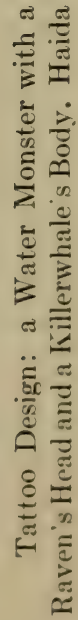


body parts treated with great freedom as to their arrangement. The composition is adapted to the shape of the surface available for decoration; the shape of body parts

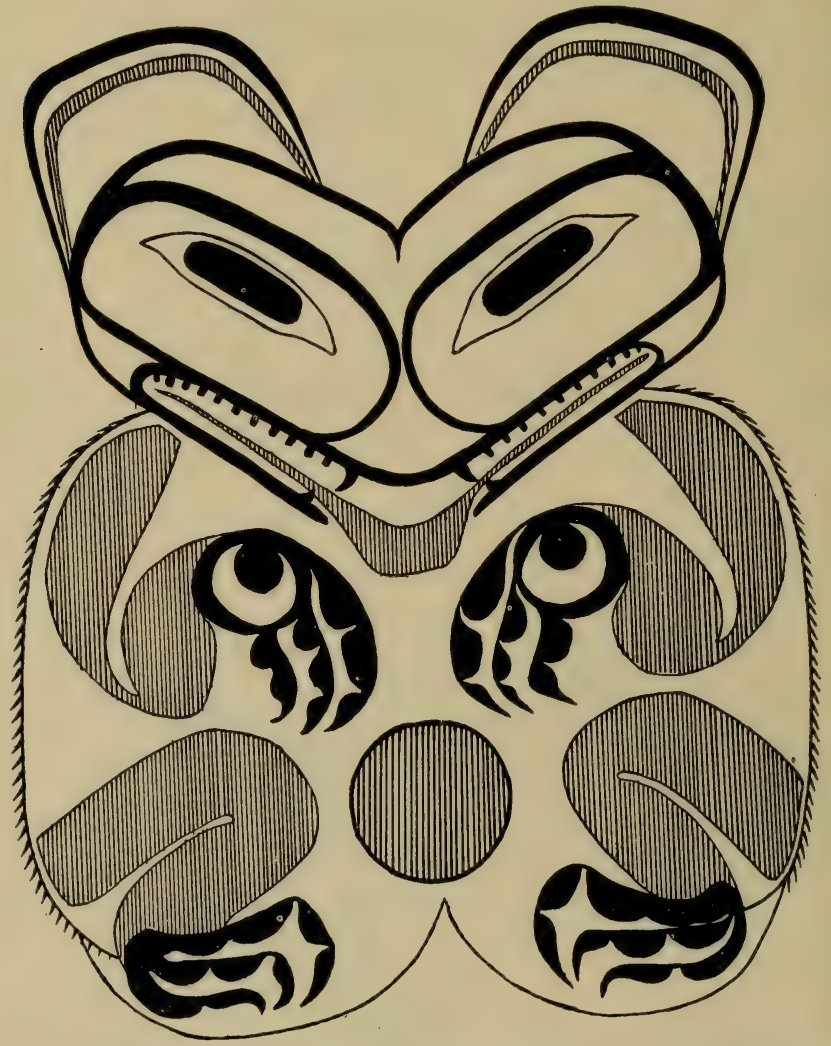

Painting from a House Front Showing a Bear as if Cut Along the Back, Giving a Symmetrical Treatment Either Side of Circular Door. Tsimshian.

is adjusted to give pleasing lines, angles give way to curves, natural disproportions are equalized, and by the use of wider and narrower lines, or varying color, ex- 

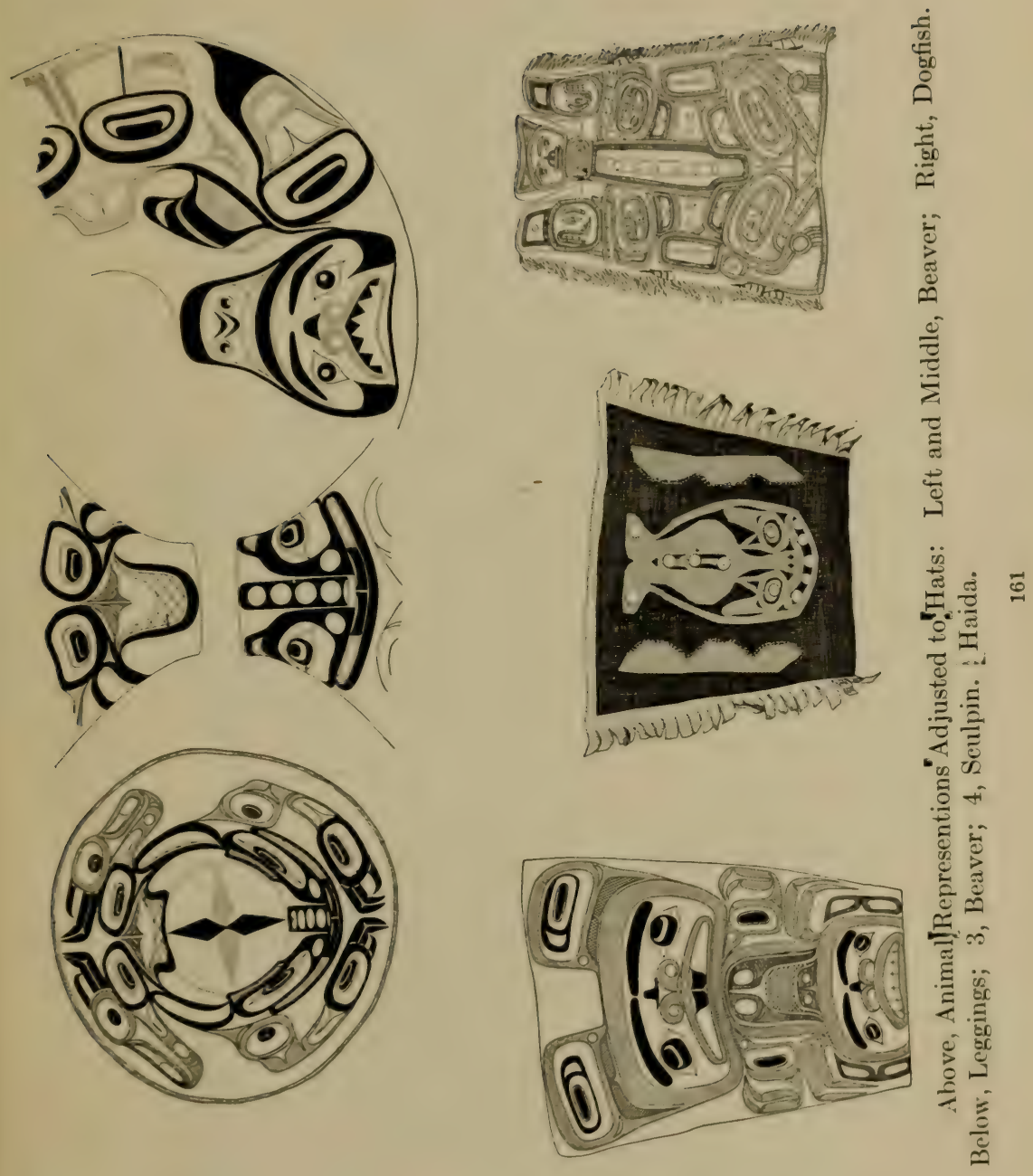


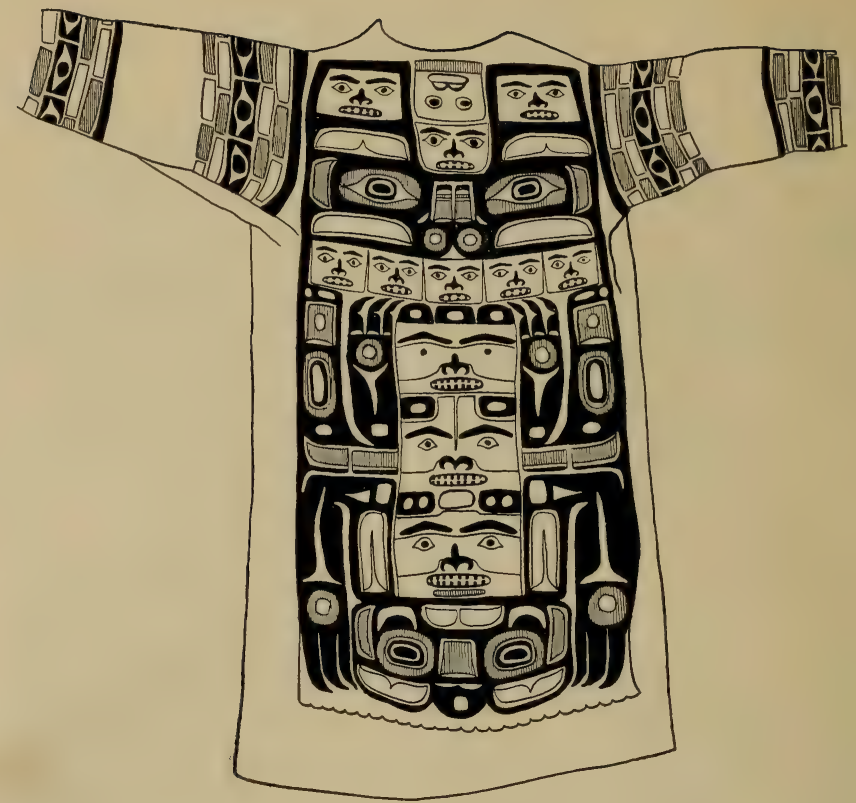

Shirt with Designs Similar to Those on Blankets. Tlingit.

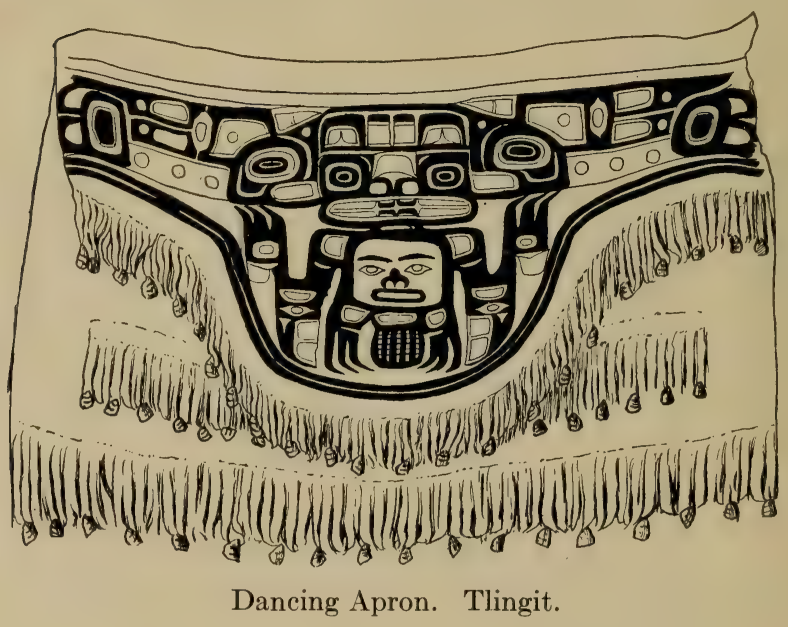



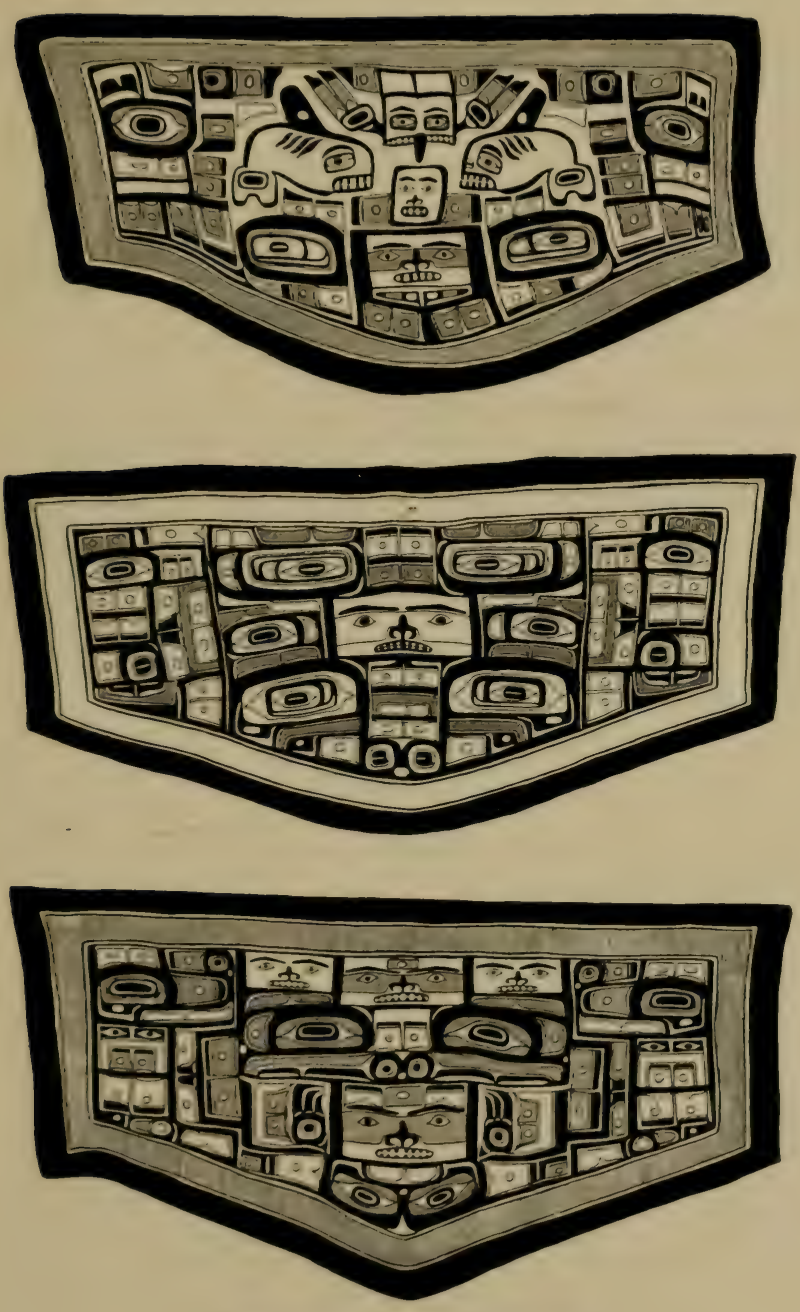

Designs on Chilkat Blankets. 

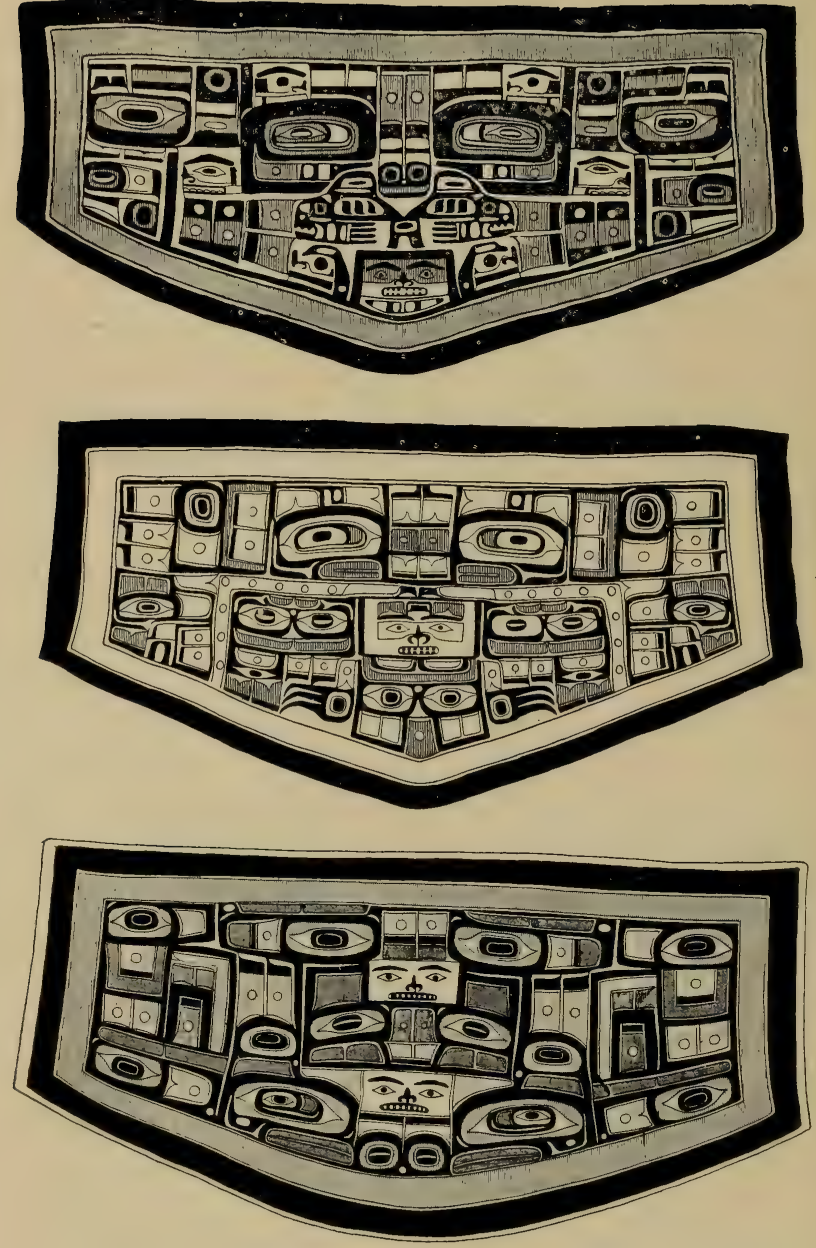

Designs on Chilkat Blankets. 
ceedingly pleasing results are obtained. So conscious has this art of dissected and freely arranged animal parts become, that the artist cuts out eyes or fins and uses them as patterns in drawing the outlines of his designs. Art of this sort is found on house fronts, settee backs, canoes, paddles, ends and sides of boxes, skin robes, and the woven blankets of the Chilkat.

We have then on the Northwest Coast, a woman's geometric decorative art of a textile origin, similar to

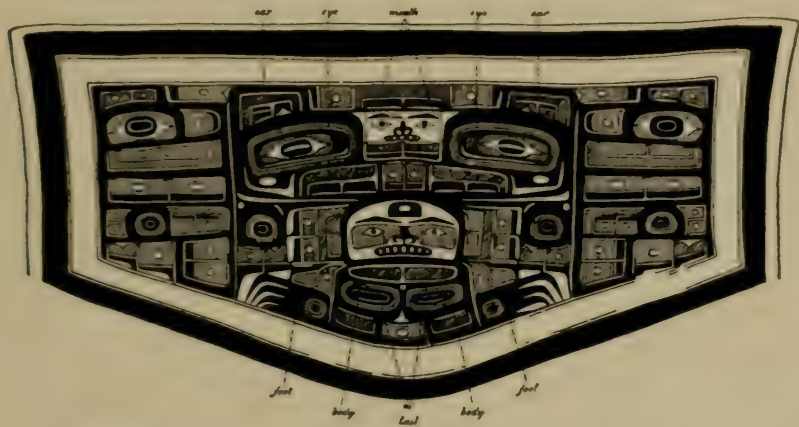

Design on Chilkat Blanket: Positions of Anatomical Parts are Indicated.

that found generally in North America; a man's realistic and representative art, in some respects similar to picture writing on birch bark and skins, but differing in that the weird and mysterious is often represented; and finally, as an outgrowth of this, an elaborate conventionalized art in which body parts having been cut free from their natural anatomical relations have been given other fixed proportions and relations according to the esthetic requirements of line and mass. 


\section{BIBLIOGRAPHY}

Boas, Franz. Indianische Sagen von der Nord-Pacifischen Kuste Amerikas. Berlin, 1895. The Decorative Art of the Indians of the North Pacific Coast. Bulletin, American Museum of Natural History, Vol. IX, pp. 123-176. New York, 1897. The Houses of the Kwakiutl Indians, British Columbia. Proceedings of the United States National Museum for 1888, pp. 197-212. The Social Organization and the Secret Societies of the Kwakiutl Indians. Report of the United States National Museum for 1895. Washington, 1897, pp. 311-738. Sixth Report on the Northwestern Tribes of Canada, in Report of the 16th Meeting of the British Association for the Advancement of Science, at Leeds, 1890. London, 1891. Tsimshian Mythology. 31st Annual Report of the Bureau of American Ethnology, 1916. Ethnology of the Kwakiutl. 35th Annual Report of the Bureau of American Ethnology, 1921. The Mythology of the Bella Coola Indians, Vol. I, part 2, Jesup North Pacific Expedition, 1898.

Boas, Franz, and Hunt, George. Kwakiutl Texts. Publications of the Jesup North Pacific Expedition, Vol. III, pp. 1-532, 1902-1905. Kwakiutl Texts (Second Series), Vol. X, pp. 1-269, 1906.

Cook, Capt. James. A Voyage to the Pacific Ocean. (In three volumes), Vol. II. London, 1785.

Dawson, George M. Report on the Queen Charlotte Islands, 1878. Montreal, 1880.

Dixon, Capt. George. A Voyage Round the World But More Particularly to the Northwest Coast of America. London, 1789. 
Emmons, Lieut. George T. The Basketry of the Tlingit. Memoirs, American Museum of Natural History Vol. III, part 2, 1903 . The Chilkat Blanket. Memoirs, American Museum of Natural History, Vol. III, part 4, 1907.

Jewitt, John R. A Narrative of the Adventures and Sufferings of John R. Jewitt. Middletown, 1815.

Kane, Paul. Wanderings of an Artist Among the Indians of North America. London, 1859.

Krrause, Dr. Aurel. Die Tlinkit-Indianer. Jena, 1885.

Lisiansky, Capt. Urey. A Voyage Round the World in the Years 1803-6. London, 1814.

Meares, John. Voyages Made in the Years 1788 and 1789 from China to the Northwest Coast of America. Londoñ, 1790.

Newcombe, Dr. C. F. Guide to Anthropological Collections in the Provincial Museum, Victoria, B. C. 1909.

de la Perouse, J. F. G. A Voyage Round the World Performed in the Years 1785-8. (In two volumes), Vol. I, London, 1799.

Sapir, Edward. Sayach'apir, A Nootka Trader in American Indian Life, pp. 297-323. New York, 1922.

Sproat, G. M. Scenes and Studies of Savage Life. London, 1868.

Swan, James G. The Indians of Cape Flattery. Smithsonian Contributions to Knowledge, Vol. XVI, p. 220. Washington.

Swanton, John R. Haida Texts: Masset Dialect. Vol. X, part 2. Jesup North Pacific Expedition, 19051908. Haida Texts and Myths: Skidegate Dialect. Bulletin 29, Bureau of American Ethnology, 1905. The Haida of Queen Charlotte Islands. Vol. V, part 1, Jesup North Pacific Expedition, 1905. Tlingit Myths and Texts. Bulletin 39, Bureau of American Ethnology, 1909. Social Condition, Beliefs, and Linguistic Relationship of the Tlingit Indians. 26th Annual Report Bureau of American Ethnology, 1908, pp. 391-512. 
Vancouver, Capt. George. A Voyage of Discovery to the North Pacific Ocean and Round the World. (Three volumes), London, 1798. 


\section{INDEX}

Alberni Sound, trails, 17.

Aleutian Islands, twined weaving in, 53 .

Aleuts brought over, 24 .

Adzes, 36, 39, 41.

Alaska, 17, 20; first visited, 24; transfer of, 24.

Animals, Indian conception of, 112, 113, 114; Land, 79.

Aprons, 82; represented in art, $151,-153,155,156,158,159,160$.

Armor, Kinds of, 106, 107.

Arrows, 76, 107.

Art, Conventionalized, 151-156; Decorative, 142-144; Grotesque, 146-150; Northwest Coast, 142-165.

Arts, Textile, 46-59; in wood, 3545.

Astor, John Jacob, 24.

Astoria, Establishment of, 24.

Athapascan, Location of, 13.

Ayala, don Juan de, commander, 21.

Band, ankle, 82 .

Baranoff, Settlement made by, 24 . Barefootedness, Extent of, 79, 81. Bark, Garments of, 82 ; Use made of shredded, 82 .

Basketry, 51, 53, 54, 142; methods of manufacture, 51 ; ornamentation, 53, 54; Tlingit, illustrated, 52, 144; material used, 53; preparation of material, 53 ; use, 54.

Bear, Taboos concerning, 79; Ceremony over, 118.

Beaver, in myth, 136.

Behring, landing by, 20, 21.
Belief regarding animals, 112-114.

Beliefs, Religious, 111-116.

Bella Bella, Divisions of the, 96 ; First mention of the, 23; Location of the, 14; Winter ceremonies of the, 121 .

Bella Coola linguistic relationship, 93; belief regarding death, 135; climate, 17 ; conception of supernatural, 113; deities, 113, 114; divisions of year, 129; First mention of the, 23; Inherited duties among, 88, 89; Intermarriage among the, 97,102 ; names and honors acquired, 87 , 88; River, 24, 89; Salmon taboo among the, 117, 118; winter ceremonies, 121.

Bending of wood, 39, 40, 41, 42.

Betrothal, Potlateh for, 131.

Birth, Supernatural control of, 112, 114.

Blankets, Decoration of, 142; Loom for Chilkat, 56; Salish, 58; Cedar bark, 54, 55; Chilkat, 55-57, 163-165.

Bodega Bay, 20.

Bodega, don de la, commander, 21.

Bone, Uses made of, $73,82,107$, 108.

Boussole, ship, 22.

Boxes, Decoration of, 150, 156 157, 165; Making of, 39-42; Use of, 41, 150 .

Bows, 77, 107.

Bracelets, 82, 157.

Bracken roots used as food, 75 .

British Columbia, 14, 17, 20.

Burial, Canoe, 98; Customs, 98, 101; duties, 132; recompensed 
by potlateh, 95; of relative.

Colors, how produced. 54. 56.

Feast at. 87; Shaman, 120, 121; Tree. 98.

Burke's Channel, 14. 24.

California, 15. 16.

Camas used for food. 77 .

Cannibalism. Ceremonial. 127, 125 .

Cannibal Society, hamatsa, 86. 114. 123. 126; spirit, 123; Home of. 114 .

Canoe Burial, 98.

Canoes, 33-35. 109; Making of, 44, Trpes of, 33.

Carrying straps, 48, 51 .

Carved ornamentation. 151, 152. $155-156$.

Carving, forms of, and material used, 142, 143, 144 .

Cat's cradles. 106 .

Cedar bark blankets, 54. 55, 82, Tse of, $41,46.82$.

Ceremonial cleanness, 109, 116. 117.

Ceremonies, Character of religious. 111; Master of. 125; Thingit. 130; Winter, 121-130.

Chief harpooner, Regulations regarding, 59, 60 .

Chiefs, 89, 90. 92. 93.

Chilkat loom, 56; blankets, 55. 56 . 57. 163-165; houses, 31; River, 16. 20; Trails of the, 19 .

Chisels. 36. 38, 40 .

Cleanness, Ceremonial, 109, 116 . 117,122 .

Climate. 17.

Clothing. 80, 81, 82.

Clover gardens, 77 .

Clover used as food, 75,77 .

Clubs as weapons, 107 .

Cod fishing by K wakiutl, 20, 63.

Columns, Memorial, 101.

Conventionalized art, 151-156.

Cook, Captain James, 22.

Cooking, 74, 75.

Coppers, 91, 92. 132.

Corpse eating bre cannibal, 128.

Cowichan, Location of, 17.

Crab-apples used for food, 75 .

Cradle, $\$ 2$.

Creation, Conception of, 136.

Creek women, Power of, 112.

Cremation, 101.

Culture, Material, 25-84; Subdivisions of Northwest, 25.

Curing Methods, 119.

Currants used for food, 75 .

Customs, Burial, 98, 101; Marriage, 103, 104, 105.

Dance pole, Winter, 122.

Deadfalls. 78,79 .

Death, Beliefs concerning, 134, 135.

Decoration and dress, 79-84;

Blanket, 142, 163-165; by dissection, 156-158; Geometric, 165 ; on mats, 142 ; produced by women, 143; Srmmetry in, 158-160; Textile. 142-146.

Deer, 79 .

Deformed heads, Types of, 83,84 .

Deities, Bella Coola, 113, 114; Haida, 111, 112, 113.

Descent, counting of, among the Kwakiutl, 96; Haida, 94; Salish, 96; Tlingit, 95.

Designs, 57, 142-165; Tattoo, 84, 159 .

Dice games, 106.

Discovery of Pacific Coast, 20-24.

Dishes, 42. 
Dissections in art, 156, 157, 158.

Divisions, Exogamous, 94-97.

Dixon, George, commander, 23.

Dixon's Entrance, 16, 62.

Djilagons, Power of, 112.

Dog eaters, 130.

Dog salmon, 67, 68 .

Dogs, source of wool, 58 .

Down, as symbol, 82 .

Drake, Francis, Visit by, 20.

Dress and Decoration, 79-84; of hair of shaman, 120, 121; Women's, 82,84 .

Dugout dishes, 42, 155, 156.

Duties, Inherited, 88, 89.

Dzonoqwa, supernatural being, 139.

Eagle, Adventures of, 136 .

Eagles, socisl division, 94, 95.

Ear pendants, 82.

Earthquakes, cause of, 112; ceremony, 140.

East India Company, Ships of, 22.

Eel grass used for food, 40, 75 .

Elderberries used for food, 75 .

Engagement, Marriage, 105.

Erernia rulpina, tree moss, 56.

Eskimo, Location of, 13.

Exogamous divisions, 94-97, 102.

Family, Political functions of, 95; traditions, 138-141.

Fauna, 19, 20.

Feasts, 86, 87, 88, 90, 123.

Feathers, Use made of, 82.

Fern roots used for food, 75 .

Fighting, Methods of, 109; Motives for, 107, 108, 109, 140-141.

Fire throwers, 130.

Fireweed clan, 95, 96.

Fish, Beliefs concerning, 112, 115 . 116; baskets, 64 .
Fish-hooks, how made, 41, 42.

Fishing taboos, 117, 118.

Fish weirs, 64,67 .

Fitzhugh Sound, 14.

Flora, 19.

Food, 16; Securing of, 59-79;

Offerings of, 117 .

Fraser River, 15; Salish of, 25.

Fuca, Jean de, Visit of, 20.

Fur trade, 24, 81.

Future world, 134-135.

Gaff hook, 67 .

Gambling, 105.

Games, 105-106.

Geographical groups, Linguistic and, 93,94 .

Gibbs, George, Statement of, 25, 26.

Gitksan, Clans of the, 95; Location of the. 94 .

Goats, Method of hunting mountain, 79 .

Gods, Bella Coola, 113; Haida, 111; Kwakiutl, 114, 115.

Gooseberries, use for food, 75 .

Grave monuments, 114, 146.

Grease trails, 17,19 .

Grotesque art, 146-150.

Habitat, 13-20.

Haida as linguistic group, 93; beliefs regarding fish, birds, and animals, 112; ceremonies, 129. 130; conception of beginning. 136; Cremation among, 101; deities, Power of, 111, 112, 113; Deseription published of, 23 ; engagement for marriage, 105; Halibut used by the, 62; Isolation of the, 93, 94; women, Labret worn by, 82,84 ; Loca- 
tion of, 13; Main potlatch of, 132; Matrilineal groups of the, 102; Pipe-making by the, 156; practice of tattooing, 84; recording of descent, 94 , 95; regard for supreme being, 111; shamanism, 118; world, 112.

Hair, Style of dress of, $80,81,82$;

Dress of shaman's, 120.

Haisla, 14.

Halibut, 20; Cleaning and treatment given, 63; fishing, 62, 63 .

Hamatsa, see cannibal society, 123.

Hammers, 37, 38.

Harpooner, Regulations regarding. 59,60 .

Hats, 49, 81, 82, 161.

Heads, Types of deformed, 83, 84 .

Heiltsuk, 14, 93.

Hemlock, 19; bark, used for food, 77.

Herring, fishing for, 72; spawn, how collected, 72 .

History, Early, 20-24.

Honors, Acquiring of, 87, 88, 9092, 133, 134.

Houses, 25-33; Cooperatively built, 33; of the Chilkat, 31; of Kwakiutl, 26, 27, 29, 31; Nootka, 26; Salish, 25; of supernatural ones, 113, 114.

Huckleberries, used for food, 75.

Hudson Bay Co., Trade of, 24.

Hunting, Mountain goat, 79; Porpoise, 61, 62; Sea-otter, 24; Whale, 59.

Inherited duties, 88 , 89; possessions, $86,87,118,138$.

Kelp fish, catching of, 63 ; stems, use in fishing, 63 .

Killerwhale, 20, 95, 112, 114.
Kitimat River, Olachen in, 20.

Kitlope, Location of, 14.

Kitwankool grease trail, 19.

Klukwan, Houses at, 30, 31.

Knives, 39, 107.

Kwakiutl, 14; as linguistic group, 93; attitude toward earth burial, 98; belief regarding animals, 114; Blankets of the, 54, 55; Box-making by the, 41; conception of supernatural beings, 114; counting of descent, 96 ; marriage customs, 104, 125; distribution of wealth, 133; Divisions of the, 93; Rivalry among, 90; gods, 114, 115; grading of chiefs, 88,89 ; head deformation, 83, 84; Houses of, $25,26,27,29,31$; Inherited duties of the, 88, 89; Marriage among the, 103, 104, 122; names and honors acquired, 87 , 88,122 ; occasion for revenge, 108; Porpoise hunting by the, 61 ; secret societies, 114, 122, 123; taboo of salmon, 118; a tradition of, 138; slaves, Treatment of, 86; tree burial, 98; winter ceremonies, 121 ; method of obtaining wood, 36 .

Kyuquot Sound, trails, 17.

Labret, Wearing of, 82, 84; illustration of, 154 .

Land animals, 79 .

Lillooet, Culture of the, 15 .

Lily bulbs, Use of, 75, 77.

Linguistic groups, 14, 93, 94 .

Lisiansky, Urey, Narrative written by, 24 .

Loom, Chilkat blanket, 56; Salish, 58. 
Mackenzie, Alexander, 19, 24.

Magic performances, 128, 129.

Makah, Halibut used by, 62 ; Loeation of, 14.

Mark, Shooting at, 106.

Marriage, 101-105; among the Bella Coola, 97; customs, 103. 104, 105, 125; Honors acquired through, 87, 88, 122; Potlatch for, 131 .

Masks, Purpose of art on, 146, $147,148,150,154$.

Master of ceremonies, 125.

Material culture, 25-84.

Matrilineal groups, Purpose of, 102.

Mats, Decoration on, 47, 142; Material used in, 46, 48; Method of manufacturing, 46, $47,48,51,53$; used as clothing, 81.

Maurella, don Francisco Antonio, pilot, 21.

Meares, Capt. John, explorer, 23.

Memorial columns, 100, 101.

Metal objects, Use made of, 82 .

Mountain goats, Hunting of, 20, 79; sheep, 20.

Mythology, 135-140.

Names, Acquiring of, $87,88,123$, 132.

Nass River, 13, 17; noted for olachen, 20, 69; Trails along the, 19.

Nets, 46; Manufacture of, 46 ; Use of, $65,66,69$.

Nicotiana attenuata, tobacco, 77.

Nimkish, 17; Lake trails, 17.

Niska, Location of the, 94 .

Nootka, 14; as linguistic group, 93; Canoe of the, 33, 35; ca- noes handled by, 35; Harbor, Landing at, 21; Houses of the, 25, 26; Location of the, 14; Marriage among the, 102, 103; Mat-making by the, 48 ; methods of tree felling, 37; Names and honors acquired by the, 87,88 ; negotiations unsuccessful for transfer, 23; Position acquired through war deeds, 110 ; potlateh at maturity of girl, 131; for boy, 131; Sound, 22; Schooner built at, 23; trading post established at, 23; trails, 17; visited by John Meares, 23;

- taboos, 118; Taking of sealions by, 61; tree burial, 98; felling, 37; use made of venison, 79; whaling among, 59, 61; winter ceremonies, 121.

N. California, region of twined weaving, 53 .

Nose pendants, 82,84 .

Novice, Duties of, 125, 127; Return of, 125.

numaym, father's or mother's sept, 96.

Offerings, Food, 117, 134.

Oil feast, form of rivalry, 90.

Olachen, method of taking, 72; oil, 17, 19; process of extraction and use, 68-73; traded, 73.

Oregon, region of twined weaving, 53.

Organization, Social and Political, 85-110.

Ornamentation, Carved, 155, 156; in basketry, 54; weaving, 59; Material used in, 54 .

Ornaments, personal, 80, 84.

Pacific Coast, Discovery of, 20-24. 
Paddles for canoes, 34 .

Peace, how brought about, 110; River, 24.

Pendants, Material used in ear and nose, 82,84 .

Perouse, De la, 22.

Piercing of ears, nose, and lower lips, Feast at, 87.

Pile drivers, 69, 71.

Pipe-making, 156.

Platforms, 31, 33.

Political Organization, Social and, 85-110.

Porpoises, 20; Hunting of, 61, 62.

Port Bucarelli, Landing at, 21, 22.

Portlock, Capt., commander, 23.

Posts, Meaning of Kwakiutl carved, 140.

Potatoes, cultivated, 77.

Potlatch among the Haida, 129;

Tlingit, 101; Burial recompensed by, 95; Main, 132; Meaning of and social law regarding, 130, 131; Occasion for, 98, 101, 131; Permanent records of, 134; Purpose of, 133, 134; Wealth necessary for, 132 , 133.

Practices, Religious, 116, 117, 118.

Prince of Wales group, 16, 21.

Puberty feasts, 86,131 ; seclusion of girls, 97, 98; Taboos regarding, 97.

Public accountants, Duty of, 88.

Purification for ceremonies, 109, 122, 123.

Quatsino Sound, trails, 17.

Quileute, Whale killing by the, 59 .

Quoits, 106.

Rainfall, 17.

Rank, 85-88, 123, 133.
Raven, Adventures of, 135-138; Attitude toward, 136.

Red cedar, 19, 46.

Reincarnation of animals, Belief in, 113, 115, 116.

Religion, 111-141.

Religious beliefs, 111-116; ceremonies, 111, 121-130; practices, 116, 117, 118.

Revenge, how taken, 107, 108.

Rings, Ear and nose, 82, 84.

Rivalry between groups, 128 ; in Tlingit ceremonies, 130; of chiefs, 90, 92, 93.

Rose hips, used for food, 75.

Russians, Visit by, 20, 24.

Sails, 34 .

Salal berries, used for food; 75 .

Salish, a linguistic group, 14, 93; Basketry among, 142; blankets, 58, 59; Canoe burial among, 98; Canoe of, 33; counting of descent, 96; head deformation, 84; Houses of the, 25, 26; Location of, 14, 15; Marriage among the, 102, 104; Matmaking by the, 48 ; Salmon fishing by the, $65,66,67$.

Salmon, 20; berries, Preparation and use of, 75; method employed in catching, 63, 65, 66; as people, 115, 116, 129; Preparation for curing, 68; Superstitions regarding, 115, 116; Taboo against, 79, 117, 118; Uses made of, 68 .

San Juan de Fuca, 14, 15.

Sea-lions, 20, 61 .

Seals, 20, 62 .

Seal Society, 123.

Sea-otter hunting, 24. 
Seaweed, used for food, 75 .

Secret societies, Kwakiutl, 122129.

Selection of mates, 101, 102.

Septs, 89, 94-97.

Sewing wood, 44, 45.

Shaman, Burial of, 120, 121; performance in curing, 119; Power acquired from, 118; Foresight of, 119, 120; Hair dress of, 120; Fate of soul, 134.

Shamanism, 118, 119, 120, 121.

Shellfish, 74-75.

Shoal-Water Bay, visited, 23.

Shuswap, Culture of the, 15.

Singers, Duty of, 88.

Sitka, Settlement of, 24; spruce, 19; visited, 20, 24.

Skeena River, 13, 17; Cottonwoods along, 19; trails along, 19.

Skidegate, Engagement among the, 105 .

Slaves, Regulations regarding, 85, 86; Compulsory hair dress of, 81.

Sleight-of-hand performances, 128 , 129.

Social and Political Organization, 85-110; Distinctions, 85-97; Rank, 86.

Societies, Membership in the secret, 122.

Society, Seal, 123.

South Sea Company, organized, 22.

Spaniards, First recorded voyage of the, 21 .

Spears, Use of, 107.

Spindles, 46, 58 .

Splitting planks, Methods of, 37 , $38,39$.

Spruce root, Use of, 41, 51 .
Steaming, 41.

Stikine River, 19.

Sugar loaf head type, 84 .

Supernatural beings, Kwakiutl conception of home of, 114; Regard toward odors by, 116; Bella Coola conception of the, 113 ; visitors, 129 ; world, $\mathrm{Be}$ lief in, 111.

Supreme being, 111, 113.

Survey by Capt. Geo. Vancouver, 23.

Symmetry in decoration, 158-165.

Taboos, Enforcing of, 88, 89; Hunting and fishing, 113, 116, 117, 118; regarding puberty, 97. Tally keepers, Duty of, 88 .

Tattooing designs, 84, 159; Feast for, 87; Practice of, 84 .

Textile Arts, 46-59; Decoration, 142-146.

Thaleichthys pacificus, see olachen.

Thompson Indians, Culture of the, 15; River, 15.

Thuja gigantea, see red cedar.

Thunder bird, Power of the, 112, 139.

Tlingit, as linguistic group, 93; basketry, 46, 53, 54, 142, 144; blanket weaving, 46 , conception of beginnings, 136; cremation, 101 ; decoration of masks, 146 ; Description of, published, 23; encountered, 23; Fort destroyed by the, 24; knives, 107; women, Labret in lip of, 82,84 ; Location of the, 13; Main potlatch of the, 130, 132; Matrilineal groups of the, 95, 102; Occasion for ceremonies among the, 101, 130; pipe-making, 156; 
recording of descent, 95, 96; shamanism, 118, 121; Treatment of slaves by, 86 ; trophies, 110.

Tobacco, use and growing, 77 .

Tools, 36-41.

Topography of North Pacific Coast, 15, 16.

Totem poles, Significance of, 146 , 149, 150, 151, 152.

Trade, Fur, 24, 81; in Grease, 17, 19.

Trading ships, 22, 23.

Traditions, Family, 138-141.

Trails, 17-19.

Travel along Northwest Coast, 16, 33 .

Tree burial, 98, 99 .

Tribes, Northwest Coast, 13.

Trophies, Ceremony regarding, 110.

Tschirikow, Landing by, 20, 21 .

Tsimshian, as linguistic group, 93; Clans of the, 95 ; conception of the beginning, 136; cremation, 101; Distribution of the, 93, 94; First mention of the, 23; life of, 14; Location of, 13; Main potlatch of the, 132; marriage customs, 103; Septs among the, 89; Taboos among the, 117, 118; women, Labret in lips of, 82,84 .

Twining, kinds and use, 53 .

Vancouver Island, 14, 17; Flora of, 19 ; trails, 17 .

Vancouver's Survey, 23.

Vegetable food, $75,77$.
Victoria, 14

Wakashan, Location of the, 14.

Warfare, 106-110.

War, Methods employed in, 109; Position acquired through deeds of, 110.

Wealth, Distribution of, 133; necessary for potlatch, 132, 133 .

Weapons, 107, 108.

Weaving, process and ornamentation, 58,59 .

Weirs, use, 67.

Whales, 20.

Whale, tradition of, 138.

Whaling, 59, 60, 61 .

Wigit, Power of, 112.

Winter ceremonies, 121-130; dance pole, 122.

Wiwomasgem, Kwakiutl sept, Abstract of myth of, 139, 140.

Wolf, name of social division, 95 .

Women's dress, 82,84 .

Wood, Articles made of, 45; bending, Methods employed in, $39,40,41,42$; earving, Art of, 142; Methods of splitting, 36, 37; sewing, Methods of, and where practiced, 44, 45; Use made of, $35,36,45,82$; work, $35-45$.

World, Conception of, 113; Future, 134, 135.

Wrangell, Trade at, 19.

$X$ wexwe, ceremony of earthquake, 140.

Yellow cedar, 19.

Yukon River, 19; Valley, 13. 


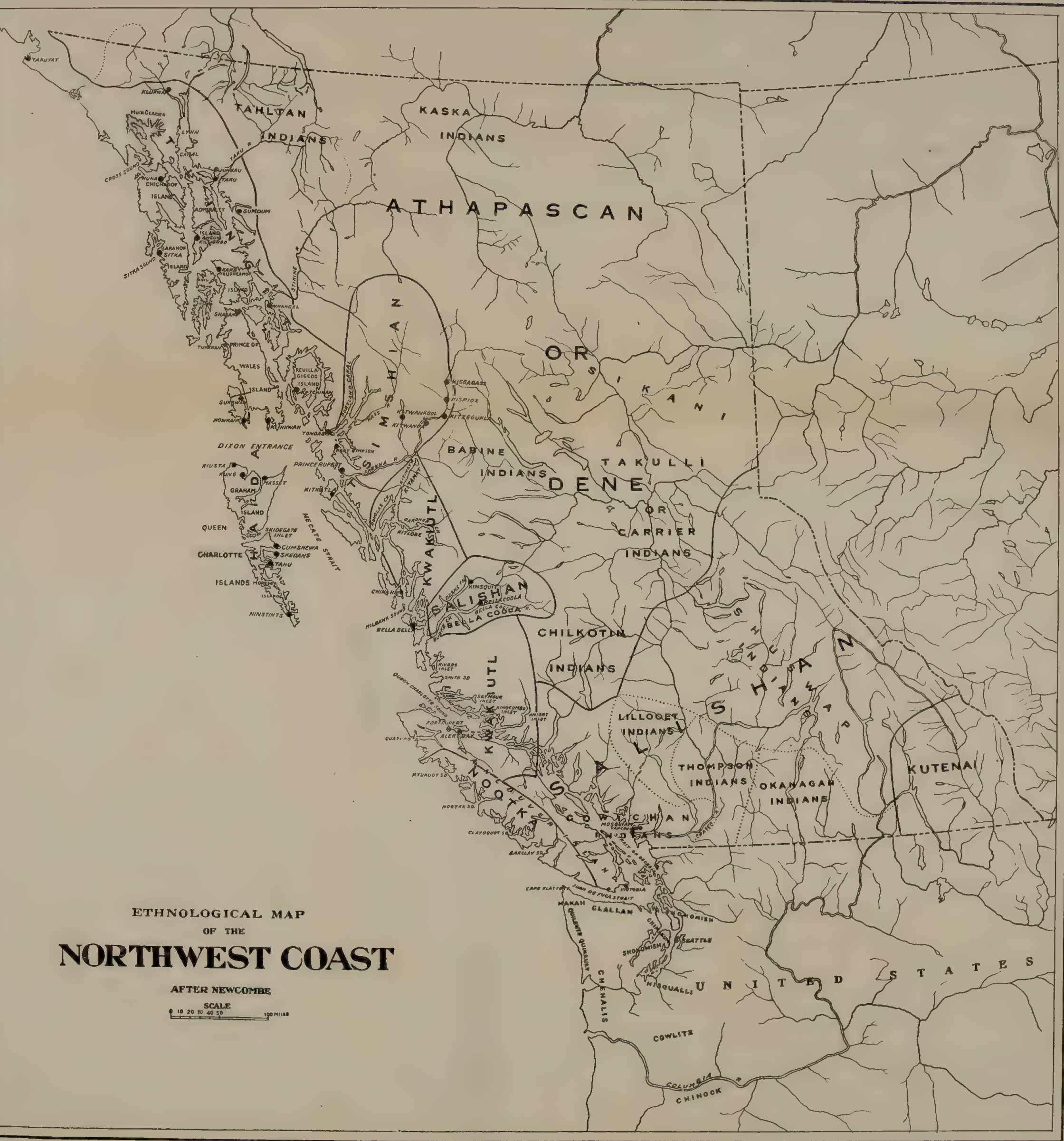


खи 




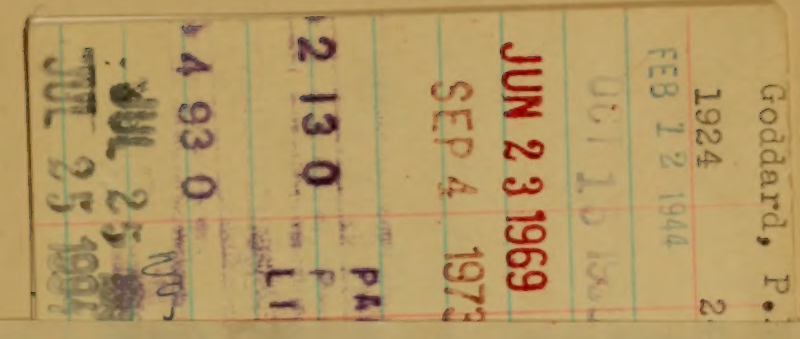


